UNIVERSIDADE DE SÃO PAULO

INSTITUTO DE GEOCIÊNCIAS

\title{
AVALIAÇÃO HIDROGEOLÓGICA E HIDROGEOQUÍMICA EM ÁREA CONTAMINADA POR MANGANÊS NA REGIÃO DE SUZANO - SP
}

\author{
VINICIUS ISHIMINE
}

Orientador: Dr. Everton de Oliveira

DISSERTAÇÃO DE MESTRADO

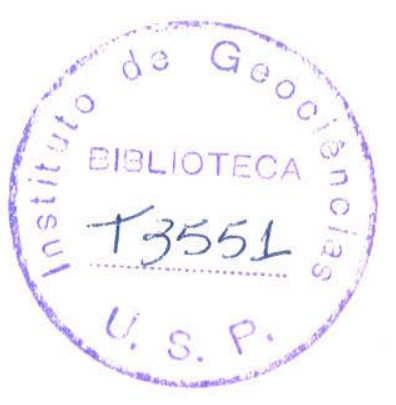

COMISSÃO JULGADORA

Nome

Presidente:

Dr. Everton de Oliveira

Examinadores: Prof. Dr. Chang Hung Kiang

Prof. Dr. Joel Barbujiani Sígolo

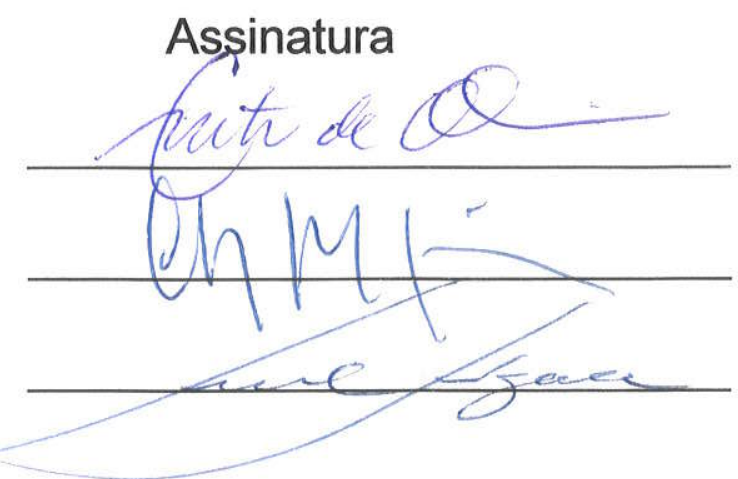

SÃO PAULO

2002 
UNIVERSIDADE DE SÃO PAULO

INSTITUTO DE GEOCIÊNCIAS

DEDALUS - Acervo - IGC

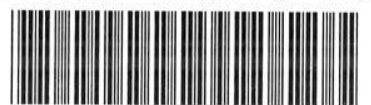

30900010303

\section{AVALIAÇÃO HIDROGEOLÓGICA E HIDROGEOQUÍMICA EM ÁREA CONTAMINADA POR MANGANÊS NA REGIÃO DE SUZANO - SP}

Vinicius Ishimine

Orientador: Prof. Dr. Everton de Oliveira

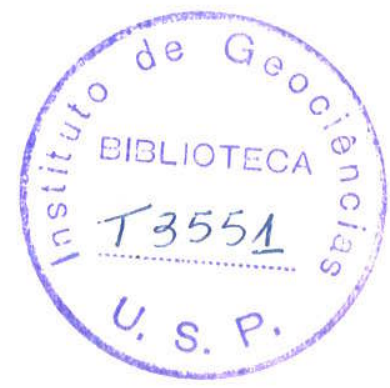

DISSERTAÇÃO DE MESTRADO

Programa de Pós-Graduação em Recursos Minerais e Hidrogeologia

SÃO PAULO

2002 
Índice

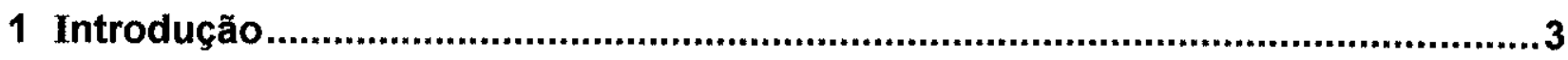

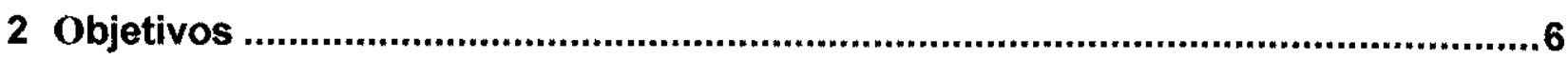

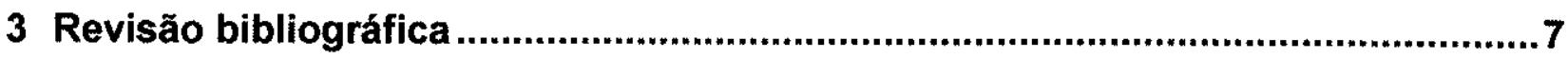

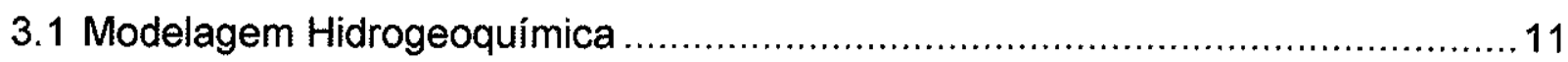

4 Metodologia

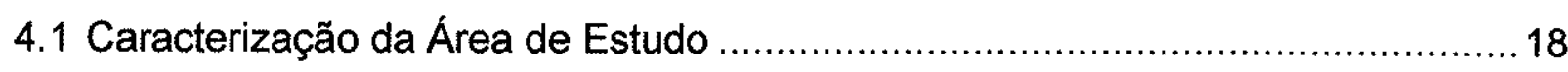

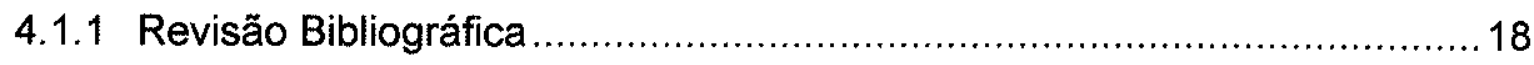

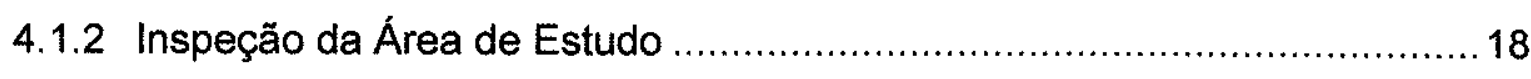

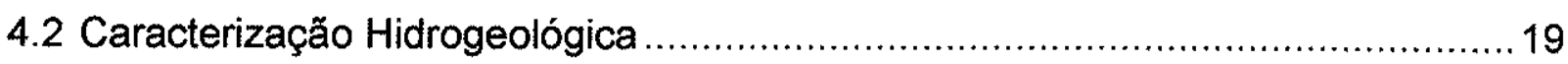

4.2.1 Modelo Hidrogeológico Conceitual ..................................................... 19

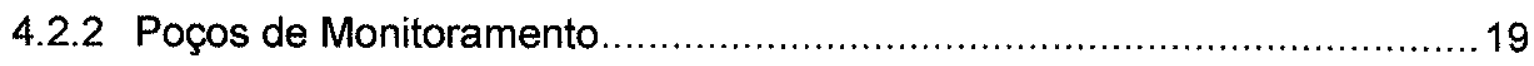

4.2.3 Determinação da Condutividade Hidráulica ...........................................20

4.2.4 Levantamento Planialtimétrico ...............................................................21

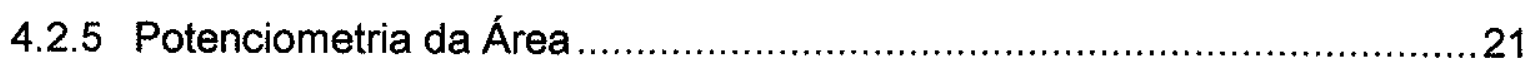

4.2.6 Determinação da Velocidade da Água Subterrânea ................................21

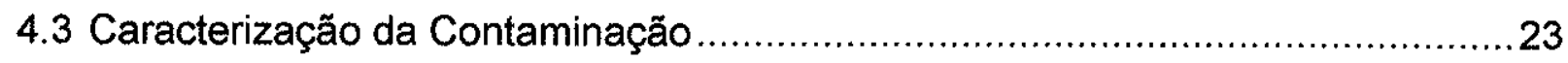

4.3.1 Medidas dos Parâmetros Físico-Químicos da Água Subterrânea.............23

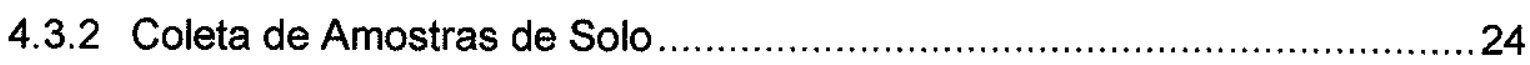

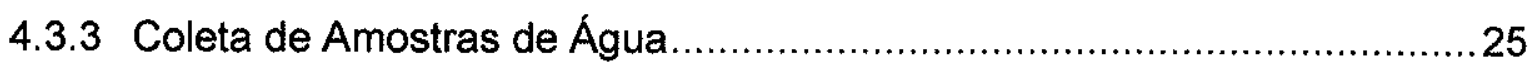

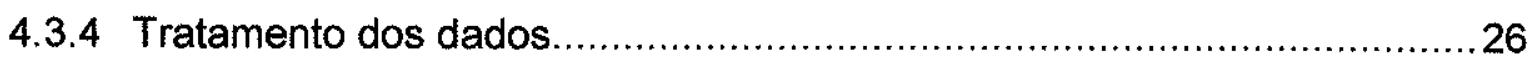

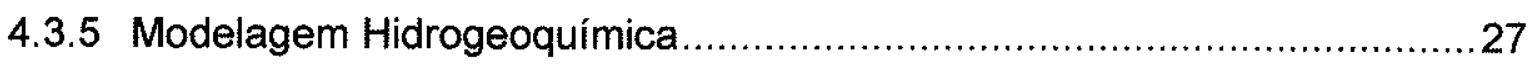

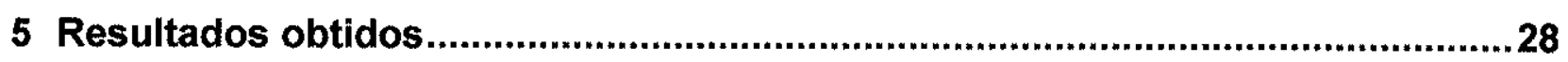

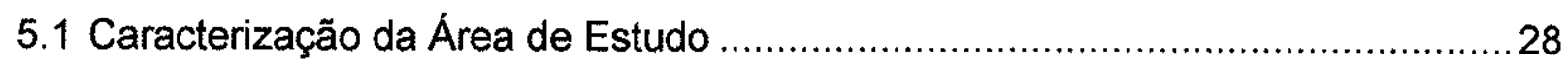

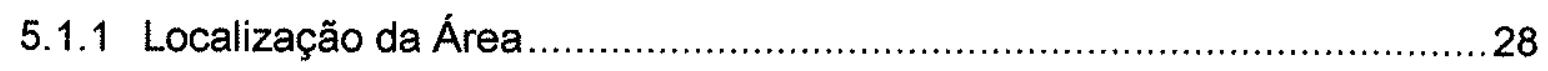

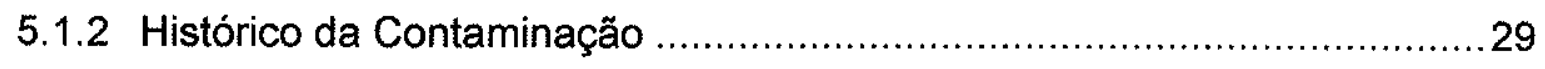

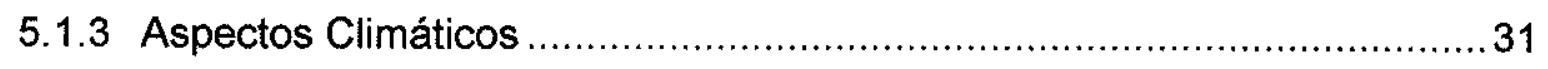




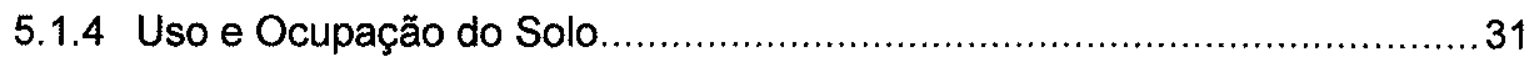

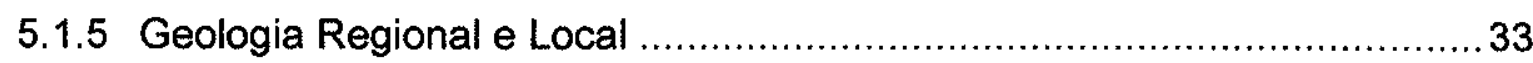

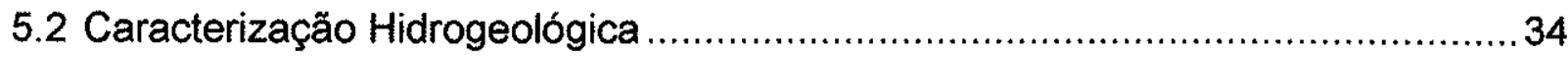

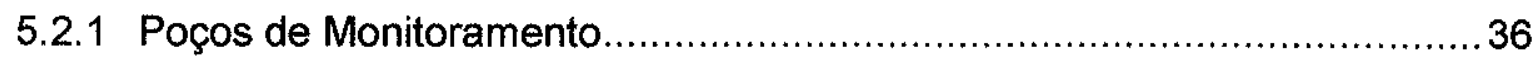

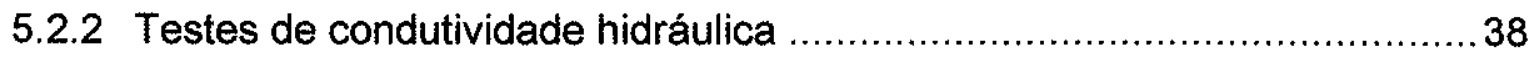

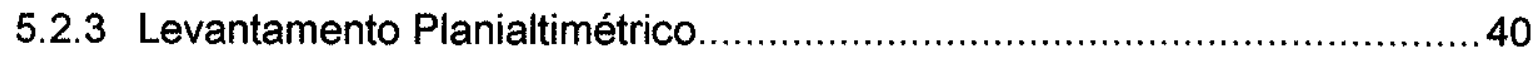

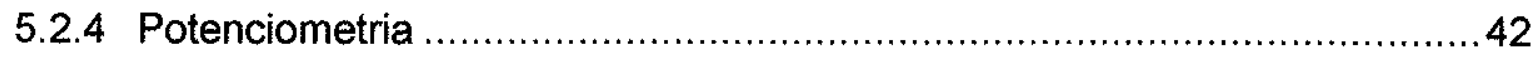

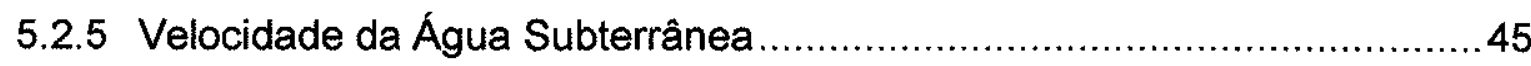

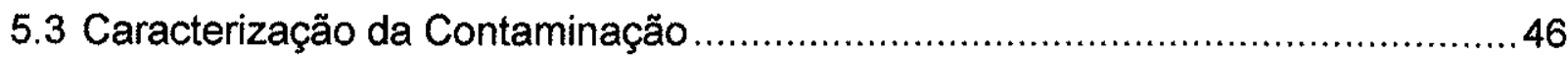

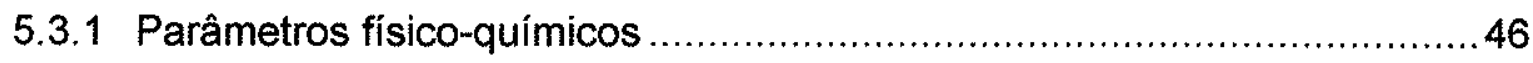

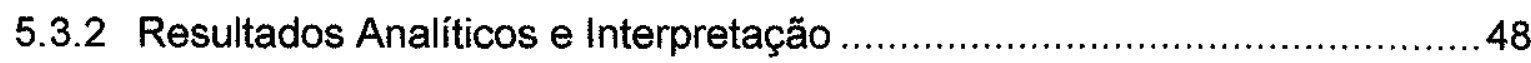

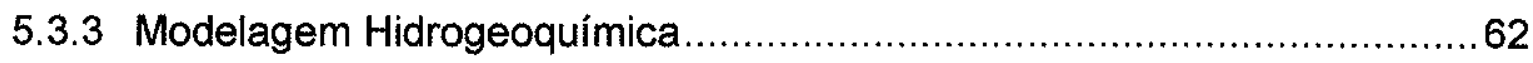

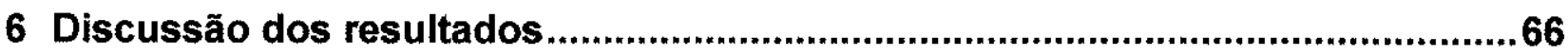

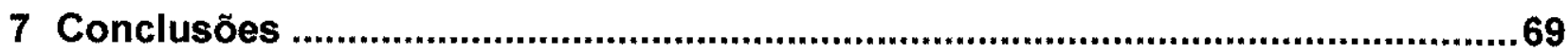

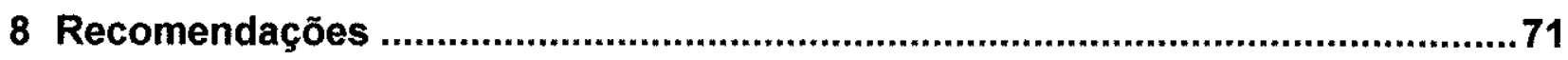

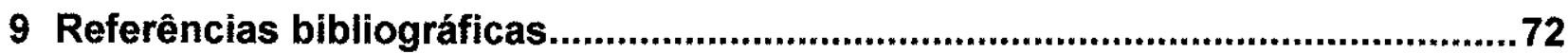




\section{Índice de Tabelas}

Tabela 01 - Porosidade efetiva para fluxo (\%) 22

Tabela 02 - Resultados dos Slug Tests 38

Tabela 03 - Cotas Altimétricas 40

Tabela 04 - Dados hidrogeológicos 45

Tabela 05 - Valores de pH e Eh obtidos em outubro/98 nos PMs. 46

Tabela 06 - Valores de pH e Eh obtidos em abril/99 nos PMs, na área alagadiça e água superficial 47

Tabela 07 - Resumo das concentrações de manganês e sulfato (mg/L) 48

Tabela 08 - Resultados analíticos das amostras de solo $(\mathrm{mg} / \mathrm{Kg})$. 53

Tabela 09 - Resumo das concentrações de manganês e sulfato (mg/L) 58

Tabela 10 - Modelagem hidrogeoquímica da água subterrânea (outubro/98) 63

Tabela 11 - Modelagem hidrogeoquímica da água subterrânea (abril/99) .64

Tabela 12 - Modelagem hidrogeoquímica da água subterrânea da área alagadiça... ...64

Tabela 13 - Modelagem hidrogeoquímica da água superficial .65 


\section{Índice de Figuras}

Figura 01 - Localização da área

Figura 02 - Mapa com a localização aproximada do rejeito e edificações da área 30

Figura 03 - Área de proteção de mananciais 31

Figura 04 - Modelo hidrogeológico para a área em estudo. 35

Figura 05 - Mapa de localização dos poços. 37

Figura 06 - Slug tests realizados

Figura 07 - Mapa representando as cotas altimétricas

Figura 08 - Mapa potenciométrico (outubro/98)

Figura 09 - Mapa potenciométrico (abril/99) 44

Figura 10 - Pluma de contaminação para manganês (outubro/98)

Figura 11 - Pluma de contaminação para sulfato (outubro/98) 50

Figura 12 - Diagrama de equilibrio Eh-pH para o sistema Mn-O-H (outubro/98) 51

Figura 13 - Localização dos pontos de amostragem de solo 54 
Figura 14 - Diagrama de equilíbrio Eh-pH para o sistema Mn-O-H (abril/99) ................56

Figura 15 - Pluma de contaminação para manganês (abril/99) ................................60

Figura 16 - Pluma de contaminação para sulfato (abril/99) .......................................61 
Índice de Fotos

\section{Foto 01}

Vista do poço localizado a montante

Foto 02

Medida de Eh e $\mathrm{pH}$ in situ.

Foto 03

Procedimento de amostragem da água subterrânea - Filtragem da água........25

Foto 04

Vista da Lagoa.

Foto 05

Área alagadiça a jusante. 34

Foto 06

Área alagadiça entre a área e a estrada de ferro.

\section{Foto 07}

Tubulação que corta a estrada de ferro. 
Índice de Apêndices

\section{Apêndice I}

Perfis construtivos dos poços de monitoramento .75

Apêndice II

Resultados analíticos do monitoramento realizado em outubro de 1998 82

\section{Apêndice III}

Resultados analíticos do monitoramento realizado em abril de 1999 .84

\section{Apêndice IV}

Dados de entrada do programa Wateq $4 \mathrm{f}$ referente ao PM-01 86 
Aos meus queridos pais, José e Edneia Ishimine in memorian 


\section{Agradecimentos}

Ao Prof. Dr. Everton de Oliveira pela amizade, orientação e principalmente pela confiança depositada.

Ao Departamento de Geologia Sedimentar e Ambiental do Instituto de Geociências da Universidade de São Paulo pela oportunidade da realização deste trabalho.

À Coordenação de Aperfeiçoamento de Pessoal de Nível superior - CAPES pela bolsa de estudos concedida.

Ao Prof. Dr. Uriel Duarte pelo apoio necessário durante o período.

Ao Prof. Dr. Ondrej Sracek pela contribuição imprescindivel neste trabalho.

Aos grandes amigos Celso Kolesnikovas e Flavio Augusto Ferlini Salles pela colaboração, apoio e incentivo em tudo.

À HIDROPLAN - Hidrogeologia e Planejamento Ambiental S/C Ltda.

Aos senhores Francisco Fidalgo e Fernando César Fernandes que possibilitaram este projeto.

Aos eternos amigos de turma Luis Fernando Miliorini, Eduardo Antônio Gomes, Jorge Abujamra Neto, Sandro Mateus Gonçalves da Silva, Gaston Enrich Rojas, Guilherme de Moraes Perpétuo, João Paulo Souza de Toledo, Claudia Luciana Varnier, Jeane Gláucia dos Santos, Cristiane Aily, Artur Deodato Alves, Silvano de Jesus Clarimundo, Edson Rogério Batello.

Aos amigos Luis Cláudio da Fonte, Alexandre Guilherme Serafini, Carlos Alberto dos Santos, Alessandro Cesarino, Alexandre Tomio, Eurélio Toso Junior, Guilherme Bechara, Marcelo Bárbara, Marcelo Itacarambi, Ivan Rosas Teixeira, Alessandro Labaki e Alejandra Penaloza.

À Ana Paula e Magali da seção de pós-graduação.

Aos professores da graduação e da pós-graduação que contribuíram diretamente para minha formação.

Aos amigos que não pertencem ao "mundo geológico" e que indiretamente também contribuíram.

À minha mãe Edneia Ishimine. Ao meu pai José $Y$. Ishimine. Ainda muito presentes na minha vida.

À pessoa mais importante do mundo, minha irmã, Jussara Ishimine. 


\section{Resumo}

A prática antiga de disposição de resíduos de óxido de manganês em valas sem impermeabilização permitiu a contaminação de solo e água subterrânea por manganês em uma área em Suzano, São Paulo. No local, foram mapeadas duas fontes de contaminação, a principal delas encontra-se enterrada em terreno adjacente à área da indústria, e a secundária, que não foi formada por disposição voluntária de resíduo no solo, encontra-se na área da indústria, como resultado de deposição de material particulado liberado durante o manuseio do produto.

Testes de condutividade hidráulica in-situ apresentaram valores de $K$ na ordem de $10^{-7} \mathrm{~m} / \mathrm{s}$. A velocidade da água subterrânea encontra-se no intervalo entre $0,33 \mathrm{e}$ $17,26 \mathrm{~cm} / \mathrm{dia}$. Os resultados analíticos nas amostras de água subterrânea indicaram presença de manganês com valores acima dos limites estabelecidos pela Portaria 1469 do Ministério da Saúde na maioria dos poços de monitoramento (Valor Máximo Permitido, $0,10 \mathrm{mg} / \mathrm{L}$ ), alcançando valores máximos de $6.800 \mathrm{mg} / \mathrm{L}$ no primeiro evento de monitoramento (outubro/98) e $4.876 \mathrm{mg} / \mathrm{L}$ no segundo (abril/99). Amostras de solo da porção jusante da área indicaram concentrações elevadas de manganês, atingindo valores de até $41.000 \mathrm{mg} / \mathrm{Kg}$.

O mapeamento da pluma de contaminação de água subterrânea mostra que ela está inserida em parte do terreno ocupado pela área em estudo e quase que a totalidade da porção jusante a este (área alagadiça). A modelagem hidrogeoquímica realizada através do programa Wateq4f apresentou supersaturação de hidróxido de ferro na maioria das amostras indicando que muitos metais podem estar adsorvidos neste complexo. Muitas amostras indicaram presença de sulfato de manganês, $\mathrm{MnSO}_{4}{ }^{\circ}$ (aq).

Devido às altas concentrações de manganês encontradas em solo e água subterrânea, recomenda-se a execução de ações corretivas, uma vez que o local encontra-se inserido numa Área de Proteção de Mananciais. 


\section{Abstract}

The past practice of burying waste of manganese oxide in open, unprepared ditches in an industrial site in Suzano, São Paulo, has originated soil and groundwater contamination. Two sources of contamination were mapped at the site and its neighbourhood. The main source was placed as buried waste on a property adjacent to the industrial área. A second source was originated from dust coming from handling material at the industry.

In situ hydraulic conductivty tests indicated $\mathrm{K}$ on the order of $10^{-7} \mathrm{~m} / \mathrm{s}$ and average linear groundwater velocity interval between 0,33 and $17,26 \mathrm{~cm} /$ dia. Chemical analyses from groundwater samples indicated manganese concentration above Brazilian standards in most monitoring wells (Portaria 1469 of the Ministério da Saúde Valor Máximo Permitido, $0,10 \mathrm{mg} / \mathrm{L}$ ). The highest manganese concentration were $6.800 \mathrm{mg} / \mathrm{L}$ in the first sampling round and $4.876 \mathrm{mg} / \mathrm{L}$ in the second. Soil samples from the downgradient portion of the area also indicated high manganese concentrations, with values as high as $41.000 \mathrm{mg} / \mathrm{Kg}$.

The mapping of the groundwater contamination plume shows only a small portion of it within the limits of the industry site. Most of plume lies downgradient of the site, in the wetlands. The hydrogeochemical modeling using Wateq4f indicated a supersaturation of iron hydroxide in most groundwater samples, which indicates that many metals might be adsorbed into these complexes. Many samples indicated the presence of manganese sulphate, $\mathrm{MnSO}_{4}{ }^{\circ}$ (aq).

Due to the very high concentration of manganese found in the area, it is recommended a corrective action for soil and groundwater, since the site is located within an Environment Protection Area (Área de Proteção de Mananciais). 


\section{INTRODUÇÃO}

Muitas indústrias têm sido importantes fontes de contaminação de solo e água subterrânea e têm causado danos ambientais de diversos graus.

Esta dissertação retrata uma indústria cujo rejeito (sulfato de manganês $\mathrm{MnSO}_{4}$ ) foi disposto em subsuperfície. Os dados levantados durante os trabalhos de campo possibilitaram uma avaliação hidrogeológica e hidrogeoquímica da área em estudo.

A indústria ocupa uma área total de $15.737,55 \mathrm{~m}^{2}$ e ainda aluga um terreno adjacente, com área aproximada de $20.000 \mathrm{~m}^{2}$.

Devido à natureza dos trabalhos da empresa, é potencializado o risco de contaminação de solo e água subterrânea. Embora, hoje em dia, este risco esteja minimizado pelos procedimentos de trabalho, a prática anterior causou problemas ambientais apresentadas adiante nesta dissertação.

Esta área apresenta-se contaminada também por outros metais, tais como zinco, cobalto e cobre. A contaminação está em fase dissolvida na água subterrânea e em fase sólida no meio poroso.

Existem duas principais fontes de contaminação na área estudada:

depósito residual (enterrado) localizado em terreno adjacente à indústria (na porção sudoeste), sendo esta a principal fonte de contaminação existente na área;

> deposição de resíduos, na forma de pó, na área de manipulação da indústria e na antiga cava localizada em seu interior.

O depósito residual foi depositado na forma de $\mathrm{MnSO}_{4}$ é a mais importante fonte de contaminação na área, uma vez que o processo de lixiviação carreia grandes concentrações destes metais para a área alagadiça, porção jusante da área fonte e região de descarga das águas subterrâneas.

O manganês é elemento essencial na alimentação dos seres vivos, entretanto se ingerido em altas concentrações ou exposto ao contato prolongado, pode causar efeitos toxicológicos danosos à saúde humana. 
Duas foram as etapas de trabalhos desenvolvidas no local. A primeira envolveu trabalhos de campo para a instalação de uma rede de poços de monitoramento do aqüífero freático, levantamento do histórico das atividades da indústria e de contaminação além de dados geológicos, geotécnicos e geomorfológicos com amostragem da água subterrânea para caracterização da situação de contaminação. A segunda etapa envolveu evento de monitoramento, com amostragem da água subterrânea para caracterização complementar da contaminação, incluindo a porção jusante da área. Nesta última etapa, foram coletadas também amostras das drenagens superficiais localizadas a jusante com o intuito de se determinar possível contaminação proveniente das áreas fontes da indústria.

O primeiro monitoramento realizado indicou altas concentrações de manganês, $6800 \mathrm{mg} / \mathrm{L}$, e sulfato, $14000 \mathrm{mg} / \mathrm{L}$, na água subterrânea, enquanto o segundo evento indicou concentrações de manganês acima de $4500 \mathrm{mg} / \mathrm{L}$ e de sulfato acima de $10000 \mathrm{mg} / \mathrm{L}$ na água subterrânea.

O $\mathrm{Mn}^{2+}$ é o principal íon presente em solução na água subterrânea, passando facilmente para o estado oxidado, $\mathrm{MnO}_{2}$, quando exposto ao ar atmosférico.

Os sais de sulfato variam de moderadamente solúveis a muito solúveis em água e quando presentes em excesso na água, se ingeridas, podem causar efeitos laxativos. $\mathrm{Na}$ presença de íons de magnésio e sódio causam distúrbios gastrointestinais.

A água é o principal solvente dos minerais com os quais entra em contato, dissolvendo-o até que o equilíbrio seja alcançado. Até que seja atingido este equilíbrio, inúmeras reações ocorrem devido à coexistência de diferentes espécies iônicas em solução (íons simples e complexos reagindo entre si e com a água). Para os cálculos destas interações foi utilizado o programa de modelagem hidrogeoquímica Wateq4f, a partir dos resultados das análises químicas das campanhas de amostragem realizadas.

O resultado final desta modelagem é a apresentação da distribuição das espécies minerais presentes na solução, além dos índices de saturação desta solução em relação aos minerais presentes. 
Estes resultados possibilitaram verificar quais minerais estão presentes na solução e precipitados em subsuperfície, direcionando assim futuras etapas de remediação da área contaminada.

Este trabalho insere-se em uma linha de pesquisa de suma importância, uma vez que o local é área de mananciais e pertencente a uma Área de Proteção Ambiental (APA), próximo à Represa Billings, de onde sai grande parte da água que abastece a cidade de São Paulo e a Grande São Paulo. 


\section{OBJETIVOS}

Avaliação hidrogeológica da área de estudos;

> Caracterização da contaminação da água subterrânea em toda a área e suas imediações;

Modelagem hidrogeoquímica da água subterrânea. 


\section{REVISÃO BIBLIOGRÁFICA}

O manganês é um metal pesado (densidade variando entre 7,2 a $7,4 \mathrm{~g} / \mathrm{cm}^{3}$ ), de coloração cinzenta e muito abundante na crosta terrestre. Pertence ao grupo VII B na classificação da Tabela Periódica, possui número atômico 25 e diferentes graus de oxidação.

Devido às suas características, o manganês é utilizado em diversos produtos industriais e na composição de adubos, como micronutriente (Melo Junior, 1998).

Segundo Hypólito (1980), o manganês ocorre principalmente nas rochas ígneas e metamórficas na forma de íons bivalentes, podendo substituir cátions como $\mathrm{Fe}^{2+}, \mathrm{Mg}^{2+}$ e $\mathrm{Ca}^{2+}$. Oxidos de manganês são freqüentemente encontrados juntos aos óxidos de ferro.

Segundo a CETESB (2001), o valor de intervenção (VI) para o manganês na água subterrânea é de $100,0 \mathrm{mg} / \mathrm{L}$ e não há indicação de carcinogenicidade. O VI indica o limite de qualidade, acima do qual existe risco à saúde humana e ao ambiente.

Os maiores efeitos da exposição prolongada ao manganês estão relacionados ao sistema nervoso central, embora a concentração mínima para que haja o distúrbio não seja conhecida. A principal via de exposição humana a este composto é a inalação, sendo que a suscetibilidade aos efeitos tóxicos é variável para cada indivíduo (CETESB, 2001).

Se exposto a este período, os sintomas apresentados podem ser dor de cabeça, irritabilidade $e$ instabilidade emocional. A ausência à exposição faz com que muitos efeitos provocados, por serem reversíveis, desapareçam do indivíduo.

Segundo Amarante (1997), embora os metais pesados sejam componentes secundários da fase sólida dos solos, eles possuem papel importante na sua fertilidade, como por exemplo manganês, zinco, cobre.

Segundo Hypólito (1980), a mobilidade de manganês durante os processos de alteração em solos, é considerada moderada, equivalente à do cobalto, níquel e cobre. 
Segundo Sígolo (1998), o manganês é extremamente sensível às variações de $\mathrm{pH}$ e Eh do solo. Em solos com extrema capacidade de oxidação, o manganês imobiliza-se, via precipitação, como hidróxidos de manganês $\left(\mathrm{Mn}^{4+}\right)$, vernadita, birnessita e outras manganitas.

Em solos, este metal pode aparecer em três estados de valência:

$>\mathrm{Mn}^{2+}$, adsorvido ou na solução do solo;

$>\mathrm{Mn}^{3+}$, como trióxido de manganês e bastante reativo;

$\mathrm{Mn}^{4+}$, como dióxido de manganês.

Nestes estados os cátions encontram-se em equilíbrio dinâmico, onde a ocorrência de $\mathrm{Mn}^{3+}$ e $\mathrm{Mn}^{4+}$ é favorecida pela elevação do $\mathrm{pH}$ e condições oxidantes, enquanto a de $\mathrm{Mn}^{2+}$, em meios com pH baixos e condições redutoras.

Ainda, segundo Sígolo (1998), podemos admitir que as principais formas de ocorrência de manganês no solo são:

Associado à estrutura dos minerais, principalmente pirolusita ou óxidos hidratados;

Em complexos com matéria orgânica solúveis ou insolúveis, podendo ser deslocado por $\mathrm{Fe}, \mathrm{Cu}$ e $\mathrm{Zn}$, os quais possuem constantes de estabilidade maior que a do $\mathrm{Mn}$.

Se as condições do solo forem redutoras não haverá precipitação de óxidos de manganês, havendo íons $\mathrm{Mn}^{2+}$ solúveis que poderão ser lixiviados.

O manganês é extremamente sensível às condições do solo (acidez, umidade, atividade biológica), portanto, sua solubilidade no solo oscila e conseqüentemente sua concentração (McBride, 1994 in Amarante, 1997).

Os óxidos de manganês possuem superfície muito reativa e devido a estas características, possuem alta capacidade de adsorção de metais pesados (Almodovar, 2000).

O manganês ocorre em dois estados de oxidação em água subterrânea, como $\mathrm{Mn}^{6+}$ e $\mathrm{Mn}^{2+}$. O $\mathrm{Mn}^{2+}$ é bastante solúvel pois não existem muitas fases minerais que controlem sua solubilidade. Segundo Appelo \& Postma (1993), em águas com alta alcalinidade e, conseqüentemente, com alta concentração de íon carbonato, acontece a precipitação de rodocrosita: 


$$
\mathrm{Mn}^{2+}+\mathrm{CO}_{3}^{2-} \rightarrow \mathrm{MnCO}_{3}(\mathrm{~s}) \quad \mathrm{K} \text { sp }=10^{-10.39}
$$

Entretanto, o campo de estabilidade de $\mathrm{MnCO}_{3}$ para a concentração de carbono total $\mathrm{C}_{\mathrm{T}}=10^{-3} \mathrm{M}(1 \mathrm{mmol} / \mathrm{L})$ começa a partir de valores de $\mathrm{pH}$ de 7,7 , aproximadamente. Abaixo deste valor de $\mathrm{pH}, \mathrm{Mn}^{+2}$ é solúvel.

Por outro lado, o manganês oxidado no estado $\mathrm{Mn}^{+4}$ é insolúvel pois precipitase prontamente sob a forma de minerais como birnessita, $\mathrm{MnO}_{2}$, e hidróxido de manganês, $\mathrm{MnOOH}$. Entretanto, a fase mineral é estável somente sob condições de altos valores de $\mathrm{pH}$ e Eh e dissolve quando estas condições se alteram.

Agentes redutores de minerais de $\mathrm{Mn}^{+4}$ podem ser matéria orgânica:

$$
\mathrm{CH}_{2} \mathrm{O}+2 \mathrm{MnO}_{2}(\mathrm{~s})+3 \mathrm{H}^{+} \rightarrow \mathrm{Mn}^{2+}+\mathrm{CO}_{2}+\mathrm{OH}^{-}+2 \mathrm{H}_{2} \mathrm{O}
$$

ou ferro $\mathrm{Fe}^{2+}$,

$$
2 \mathrm{Fe}^{2+}+\mathrm{MnO}_{2}(\mathrm{~s})+4 \mathrm{H}^{+} \rightarrow 2 \mathrm{Fe}^{3+}+\mathrm{Mn}^{2+}+2 \mathrm{H}_{2} \mathrm{O}
$$

O dióxido de carbono, resultante da oxidação da matéria orgânica (Equação 02), pode dissolver carbonatos como $\mathrm{CaCO}_{3}$ do solo e a alcalinidade provocada pode causar a precipitação de rodocrosita (Equação 1).

Outra fonte potencial de alcalinidade é a redução de sulfato:

$$
2 \mathrm{CH}_{2} \mathrm{O}+\mathrm{SO}_{4}{ }^{2-} \rightarrow \mathrm{H}_{2} \mathrm{~S}+2 \mathrm{HCO}_{3}{ }^{-}
$$

que acontece em ambientes muito redutores (Eh menor que $-0,15 \mathrm{~V}$ ) na região de $\mathrm{pH}$ neutro (Stumm \& Morgan, 1981). 
Pode-se concluir que sob condições de pH neutro ou baixo e em ambientes redutores 0 manganês é solúvel e sua concentração em água subterrânea pode ser relativamente alta (muito maior que $1 \mathrm{mg} / \mathrm{L}$ ). Quando o ambiente é oxidante e o pH é neutro ou básico, o manganês precipita-se como óxido ou hidróxido. Quando o ambiente é redutor e a água possui alta alcalinidade com valores de $\mathrm{pH}$ acima de $7,7,0$ manganês se precipita sob a forma de rodocrosita, $\mathrm{MnCO}_{3}$. 


\subsection{Modelagem Hidrogeoquímica}

A modelagem hidrogeoquímica tem como objetivo deduzir e quantificar processos químicos e biológicos que modificam a química da água subterrânea em um sistema hidrológico.

Segundo Deutsch (1997), a modelagem geoquímica procura simular as reações químicas que ocorrem entre as várias fases de um sistema.

As águas naturais e sobretudo as águas poluídas estão envolvidas em um grande número de reações químicas cujas direções e extensões podem ser determinadas através da mudança dos potenciais termodinâmicos entre os componentes que participam nestas reações (Fenzl, 1988).

Neste estudo foi utilizado o programa de modelagem hidrogeoquímica Wateq4f, da U.S. Geological Survey, cujo principal objetivo é o de calcular os índices de saturação das fases minerais (Ball \& Nordstrom, 1991). Estes cálculos são baseados em inúmeras interações que acontecem entre os íons dissolvidos, a água e o material geológico que está em contato com esta solução e são baseados em termodinâmica.

A termodinâmica estuda as diversas formas de energia envolvidas nos processos hidroquímicos e seus diferentes modos de transferência, sendo baseadas em três leis fundamentais:

$\left.1^{a}\right)$ Lei da Conservação da Energia, onde as transformações energéticas ocorrem sem perda ou ganho de energia até o estado de equilíbrio;

$2^{a}$ ) Lei da Transferência de Energia, onde ocorre uma transferência energética espontânea de um estado energético superior para outro inferior e nunca vice-versa (por exemplo, de um corpo mais quente para um mais frio);

$3^{a}$ ) Lei da Entropia, onde é definido que a zero graus Kelvin (o zero absoluto, equivalente $\mathrm{a}-273,15^{\circ} \mathrm{C}$ ) a entropia possui valor igual a zero.

A Entalpia $(H)$, é o conjunto de energia de um sistema, sendo representada pela somatória da energia interna $(E t)$ com a pressão $(P)$ e um volume $(V)$.

$$
H=E_{t}+P . V
$$


Como a entalpia depende apenas dos estados inicial $\left(H_{i}\right)$ e final $\left(H_{f}\right)$, os cálculos são baseados na variação da energia:

$$
\Delta \mathrm{H}=\mathrm{H}_{f}-\mathrm{H}_{i}
$$

(Equação 06)

A entalpia é composta por:

uma energia não disponível (S), chamada de entropia, que é o grau de desordem de um sistema

$$
\Delta S=S_{f}-S_{1}
$$

(Equação 07)

e uma energia livre $(G)$, que pode ser transformada em trabalho, chamada de energia livre de Gibbs ,

$$
\Delta G=\Delta H-T \cdot \Delta S
$$

A energia livre de Gibbs pode ser calculada pela diferença entre as somatórias das energias livres de formação dos produtos e dos reagentes, conforme expressa pela equação abaixo:

$$
\Delta G^{\circ}=\Delta G_{(\text {produto) }}^{\circ}-\Delta G_{(\text {reagentos })}^{\circ}
$$

$\Delta G$ - variação da energia livre de Gibbs a uma dada temperatura e pressão;

$\Delta G^{\circ}$ - variação da energia livre de Gibbs no estado padrão.

$O$ índice $\Delta G^{\circ}$ indica que se trata de valores calculados para as condições padrão $\left(25^{\circ} \mathrm{C}, 1 \mathrm{~atm}\right.$, solução 1 molar $)$.

Calculando-se os valores da energia livre de Gibbs, sabemos a espontaneidade de uma determinada reação química:

$\Delta \mathrm{G}<0$ - a reação é espontânea;

$\Delta G>0$ - reação não espontânea;

$\Delta \mathrm{G}=0$ - reação está em equilíbrio. 
Os dados de saída do programa Wateq4f são os índices de saturação dos minerais, onde os valores positivos indicam a saturação do mineral na solução, os valores negativos indicam a dissolução do mineral e valores nulos indicam o equilíbrio.

As coexistências de diferentes espécies iônicas em solução na água, assim como a possibilidade de formação de minerais, são conseqüentes de fenômenos reversíveis que permitem aplicar diferentes leis termodinâmicas (Szikszay, 1981).

Os conceitos termodinâmicos empregados no programa de modelagem utilizado neste trabalho são:

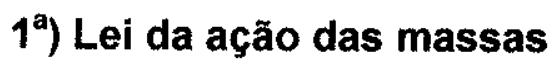

Numa dada reação reversível: $\mathrm{aA}+\mathrm{bB} \rightleftharpoons \mathrm{cC}+\mathrm{dD}$, a Lei da Ação das Massas que se aplica a todo equilíbrio químico é representada pela equação 10.

$$
K=\frac{[C][D]^{A}}{[A]^{7}[B]^{3}}
$$

$\mathrm{Na}$ lei de ação de massas, $\mathrm{K}$ caracteriza o equilíbrio e $[A],[B],[C],[D]$ representam a atividade da espécie em solução.

\section{$2^{\text {a) }}$ Coeficiente de atividade}

A atividade iônica de um íon (a) é a ação de seu campo elétrico sobre outros íns em solução ou em processo de diluição. Esta atividade é calculada através da força iônica (I) da água, cuja concentração dos ions em solução influem sobre a solubilidade de um soluto, sendo expressa pela equação:

$$
\mathrm{I}=\frac{1}{2} \Sigma \cdot C_{I} \cdot Z_{I}^{2}
$$

onde, $C_{l}$ - concentração molar do íon;

$Z_{1}$ - carga do íon 
A partir daí, conhecendo-se a força iônica de um íon, pode-se calcular a atividade iônica deste ín $\left(a_{i}\right)$ ou de uma molécula em solução através do produto do coeficiente de atividade $(\gamma)$ e a molalidade $(m)$, segundo a equação:

$$
a_{i}=\gamma . m
$$

O coeficiente de atividade $(\gamma)$ é determinado através da equação de DebyeHückel:

$$
\log \gamma_{i}=-\frac{\mathrm{A} \cdot Z_{i}^{2} \sqrt{\mathrm{I}}}{1+a_{i} \mathrm{~B} \cdot \sqrt{\mathrm{I}}}
$$

Sendo,

$\gamma_{i}$ - coeficiente de atividade;

A, B - constantes que dependem da temperatura absoluta, da constante dielétrica e da natureza do solvente;

$>Z_{i}$ - carga do íon;

$>$ I- força iônica.

A atividade iônica é parte da concentração termodinâmica que participa das reações geoquímicas. 


\section{$3^{\mathrm{a}}$ ) Equilíbrio água - minerais}

Um determinado sólido $A B$ se dissolve parcialmente gerando uma reação de equilíbrio em contato com a água:

$$
A B_{s} \leftrightarrow A^{+}+B^{-}
$$

A constante de equilíbrio desta reação de dissolução é:

$$
K=\left[A^{+}\right]\left[B^{-}\right]
$$

e por definição, a atividade de um sólido é igual a 1.

Em uma determinada solução aquosa, com uma determinada concentração de íns $\left[A^{+}\right],[B]$, sendo $P A$ o produto de atividade, temos:

$$
\mathrm{PA}=\left[A^{+}\right]\left[B^{-}\right]
$$

Comparando-se $o$ produto de atividade com a constante de equlíbrio, pode-se determinar o índice de saturação da água com relação ao mineral, ou seja, se PA $\geq \mathrm{K}$ a água está saturada em relação àquele mineral.

A determinação dos índices de saturação do programa Wateq4f se baseia nos cálculos da variação da energia livre, conforme a equação:

$$
\Delta G_{r}=2,3 \cdot R T \cdot \log \left(\frac{P A}{K}\right)
$$

Onde

$\Delta G_{\mathrm{r}}$ - variação da energia;

$R$ - constante dos gases;

$\mathrm{T}$ - temperatura.

Se: $\Delta G_{r}<0-$ a solução não está saturada; $\Delta \mathrm{G}_{\mathrm{r}} \geq 0$ - representa uma solução supersaturada ou em equilíbrio. 


\section{$4^{2}$ ) Reações de óxido-redução}

O programa Wateq4f considera para as interações, a atividade dos elétrons a partir dos valores de potencial redox Eh (que podem ser medidos diretamente em campo). Permite também calcular as atividades de diferentes espécies iônicas em solução e que entram nas reações de oxi-redução.

O valor de Eh, se não for medido em campo, pode ser calculado através da equação de Nernst:

$$
\mathrm{E} h=E^{0}+\frac{R \cdot T}{n \cdot F} \cdot \ln \frac{a_{o x}}{a_{r e d}}
$$

Onde,

$\mathrm{R}$ - constante dos gases $\left(1,987 \times 10^{-3} \mathrm{kcal} / \mathrm{mol} . \mathrm{K}\right)$;

$\mathrm{T}$ - temperatura $(\mathrm{K})$;

$\mathrm{n}$ - número de elétrons;

F - constante de Faraday $(23,06 \mathrm{kcal}$.g.eq)

a - concentração do par redox

Cálculos dos índices de saturação foram realizados por Kelly (1996) utilizando o programa Wateqf. Amostragem da água subterrânea dos poços, com filtragem das amostras através de membrana de 0,45 $\mu \mathrm{m}$ e medidas de campo in situ (temperatura, $\mathrm{pH}, \mathrm{Eh}$, condutividade) foram realizados para utilização no programa.

Nicholson et al (1982) utilizaram em seu estudo o programa Wateq2 em detrimento ao programa Wateqf em razão deste programa apresentar banco de dados termodinâmicos para metais de chumbo, níquel e zinco, que não havia na versão anteriormente citada.

Ball \& Nordstrom (1991) apresentaram quatro estudos de casos onde foi utilizado o programa Wateq4f para cálculo dos índices de saturação, que apresenta um banco de dados mais completo que as versões anteriores do programa. Nesta versão foi incluído dados do elemento manganês, alvo deste trabalho, além dos elementos 
selênio, urânio, reações de carbonato de bário, entre outros.

Versányi \& Kovács (1996) utilizaram em seus estudos o programa Wateqf para o cálculo de especiação e saturação das soluções. A metodologia descrita pelos autores incluiu medidas de campo para $\mathrm{pH}$, temperatura e em algumas amostras para Eh. Os cátions analisados em seus estudos incluíram $\mathrm{Ca}, \mathrm{Mg}, \mathrm{Na}, \mathrm{K}, \mathrm{Fe}$ e $\mathrm{Mn}$. Os Ânions analisados incluíram sulfato, alcalinidade, cloretos e nitratos. 


\section{METODOLOGIA}

A metodologia deste trabalho foi dividida em três etapas, caracterização da área de estudos, caracterização hidrogeológica e caracterização da contaminação.

\subsection{Caracterização da Área de Estudo}

\subsubsection{Revisão Bibliográfica}

Através das fontes de referência citadas no capítulo 09 foi caracterizada a área em relação à sua localização, aspectos climáticos e geológicos.

A revisão bibliográfica estendeu-se também à metodologia utilizada nesta dissertação.

\subsubsection{Inspeção da Área de Estudo}

As informações obtidas nos trabalhos iniciais de campo possibilitaram o conhecimento do problema, com determinação da fonte de contaminação e o histórico da área em estudo. 


\subsection{Caracterização Hidrogeológica}

\subsubsection{Modelo Hidrogeológico Conceitual}

Nos trabalhos de campo iniciais foram avaliadas as condições gemorfológicas, situação das drenagens locais, identificação do tipo de litologia e os possíveis condicionantes hidrogeológicos que possibilitaram a elaboração de um modelo hidrogeológico conceitual de fluxo da água subterrânea.

A partir deste modelo foram locadas as sondagens para instalação dos poços de monitoramento.

\subsubsection{Poços de Monitoramento}

A caracterização geológica e granulométrica do substrato local bem como a investigação da contaminação na água subterrânea foram feitas através da instalação de poços para monitoramento (PMs) no âmbito da área em estudo.

O método de perfuração utilizado para a construção destes poços foi o trado manual, sendo que nas porções a montante da área foi utilizado trado mecanizado. $\mathrm{O}$ diâmetro de perfuração foi de 4" (quatro polegadas).

As sondagens realizadas foram revestidas por tubulação geomecânica nervurada, com diâmetro interno útil de 2" (duas polegadas). O filtro, constituído de mesmo material, possui ranhura de $0,50 \mathrm{~mm}$ transversais para passagem da água. Como pré-filtro foi utilizada areia pré-lavada, selecionada e com granulometria adequada.

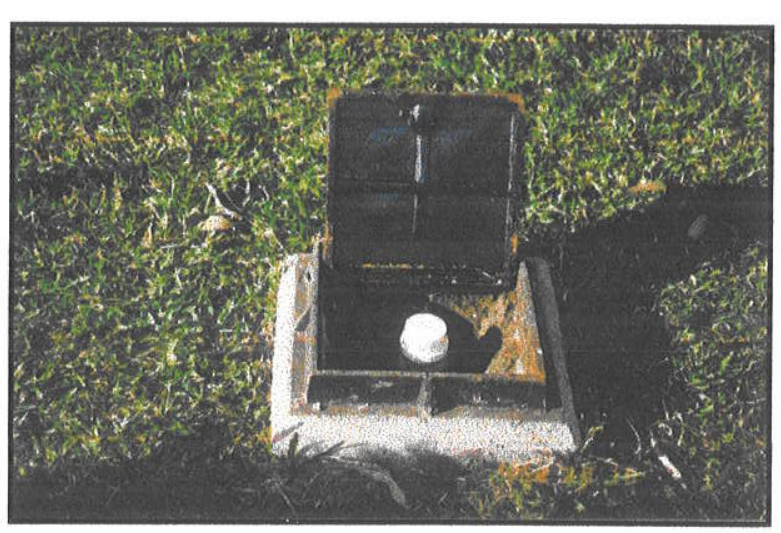

Foto 01 - Vista do poço localizado à montante $\mathrm{Na}$ parte superior do poço foi colocada, sobre uma estrutura de concreto, câmara de calçada de ferro e cap rosqueável de PVC para proteção com cadeado (Foto 01). A instalação dos PMs foi orientada pela Norma da Associação Brasileira de Normas Técnicas (ABNT) NBR 13.895. 


\subsubsection{Determinação da Condutividade Hidráulica}

A condutividade hidráulica foi determinada através de slug tests realizados in situ. Este método, desenvolvido por Hvorslev (1951) e descrito em Oliveira (1992), se baseia no tempo de recuperação do nível d'água dos poços após a inserção de sonda no poço. Este teste foi realizado em quatro poços distintos, distribuídos em cada porção da área (montante, jusante, centro e terreno adjacente à área).

Imediatamente após a inserção da sonda foi atribuído tempo de recuperação igual a zero $\left(t_{0}=0\right)$. A partir deste $t_{0}$ foram efetuadas medidas regulares dos niveis d'água ao longo do tempo até medida aproximada ao nível d'água estático obtido antes do início do ensaio.

Segundo Oliveira (1992), quando o nível d'água atingir $10 \%$ da variação máxima obtida logo após a inserção da sonda o ensaio pode ser paralisado. $O$ valor da condutividade hidráulica, para este ensaio, pode ser determinado a partir da expressão (Hvorslev, 1951):

$$
K=\frac{r^{2} \cdot \ln \frac{L}{R}}{2 \cdot L T_{0}}
$$

onde,

$\mathrm{K}$ - condutividade hidráulica $(\mathrm{L} / \mathrm{T})$;

$r$ - raio do revestimento do poço $(L)$;

$\mathrm{L}$ - comprimento do filtro (L);

$R$ - raio do filtro (L);

$T_{0}$ - tempo em que a variação do nível d'água é 0,37 da variação inicial (T). 


\subsubsection{Levantamento Planialtimétrico}

Após a instalação da rede de poços de monitoramento foi realizado levantamento planialtimétrico em toda a área de estudo, sendo levantadas todas as cotas relativas dos poços, as construções e contornos da área. Este levantamento foi realizado através de teodolito eletrônico e todos os pontos foram plotados no programa Auto Cad (versão 14). A planta apresentada foi tratada no programa Corel Draw, versão 9.0. A cota dos poços foram todas referenciadas no nivel da câmara de ferro.

\subsubsection{Potenciometria da Área}

Foram realizadas duas campanhas de monitoramento dos níveis d'água (NA) dos PMs. Estas medidas foram realizadas através de medidor de nivel d'água eletrônico.

As cotas potenciométricas foram obtidas através da diferença da cota dos poços e os NA obtidos nos monitoramentos. A partir destes dados, foram traçadas em planta as superfícies potenciométricas obtendo como resultado dois mapas potenciométricos da área de estudos. Estes mapas permitiram a determinação da direção de fluxo da água subterrânea e do gradiente hidráulico da área.

\subsubsection{Determinação da Velocidade da Água Subterrânea}

A partir do mapa potenciométrico e dos resultados de condutividade hidráulica in situ foi determinada a velocidade da água subterrânea para o local em estudo.

Das quatro medidas de condutividade hidráulica realizadas, foram utilizadas as maiores e menores medidas para a determinação da velocidade de fluxo da água subterrânea, além do maior e menor gradiente hidráulico. Foi calculada também a velocidade média, utilizando-se as médias da condutividade e do gradiente.

Com isso, foram determinadas as velocidades máximas e mínimas da água subterrânea da área em estudo obtidas através da extensão da Lei de Darcy (Freeze \& Cherry, 1979): 


$$
v=\underline{K \times i}
$$

$n_{e}$

onde,

$\mathrm{V}$ - velocidade de fluxo $(\mathrm{L} / \mathrm{T})$;

$\mathrm{K}$ - condutividade hidráulica (L/T);

i - gradiente hidráulico;

$n_{\text {ef }}$ - porosidade efetiva para fluxo.

Através da descrição granulométrica dos furos de sondagem foi determinada a porosidade efetiva do material de subsuperfície de acordo com a Tabela 01 (Fetter, 1988).

Tabela 01 - Porosidade efetiva para fluxo (\%)

\begin{tabular}{|c|c|c|c|}
\hline \multirow{2}{*}{ Material } & \multicolumn{2}{|c|}{ Porosidade específica para fluxo (\%) } \\
\cline { 2 - 4 } & Máxima & Mínima & Média \\
\hline Argila & 5 & 0 & 2 \\
\hline Areia argilosa & 12 & 3 & 7 \\
\hline Silte & 19 & 3 & 18 \\
\hline Areia fina & 28 & 10 & 21 \\
\hline Areia média & 32 & 15 & 26 \\
\hline Areia grossa & 35 & 20 & 27 \\
\hline
\end{tabular}




\subsection{Caracterização da Contaminação}

\subsubsection{Medidas dos Parâmetros Físico-Químicos da Água Subterrânea}

Antes de se realizar a amostragem da água subterrânea dos poços para análise química, foram feitas medidas in situ de parâmetros físico-químicos da água.

Os parâmetros medidos foram:

$>$ Temperatura;

$>\mathrm{pH}$;

$>$ Eh.

Para esta medida, foi utilizado bailer de polietileno esterilizado e descartável (3/4 polegada) para a retirada da amostra de água do interior dos poços. A amostra de água retirada foi acondicionada em recipiente de polietileno (com baixos traços de metais) para a realização das medidas.

Imediatamente após a retirada da amostra de água, foi medida a temperatura utilizando-se termômetro de mercúrio.

Embora a temperatura não seja uma característica química do sistema, muitas das propriedades geoquímicas (p.ex. solubilidade mineral) são sensíveis à temperatura (Deutsch, 1997).

A temperatura da água subterrânea é necessária em praticamente todos os cálculos termodinâmicos e modelos.

Para a realização das medidas de Eh e $\mathrm{pH}$, foi utilizado aparelho portátil modelo Digimed DM-2 (Foto 02). Este aparelho é dotado de eletrodos para medição destes parâmetros e deve ser calibrado diariamente Foto 02 - Medida de $\mathrm{Eh}$ e pH in situ para as medições. A calibração do eletrodo de $\mathrm{pH}$ consiste no mergulho deste em duas soluções-tampão (pH de 4,00 e 6,86). Soluções-tampão são aquelas que resistem às variações do pH e que são utilizadas como padrão para a calibração. 
$\mathrm{O} \mathrm{pH}$ é um dos mais importantes parâmetros a serem medidos em campo, sendo este parâmetro fundamental para os cálculos termodinâmicos. Uma medida precisa do $\mathrm{pH}$ em campo é importante porque grande parte dos processos da solução (complexação aquosa, solubilidade), solubilidades de gases e reações bioquímicas são sensiveis ao $\mathrm{pH}$. O pH da água subterrânea é comumente determinado pelos constituintes de carbono inorgânico em solução, podendo variar consideravelmente quando a água é exposta a condições de superfície e se equilibre com as concentrações de $\mathrm{CO}_{2}$ atmosférico (Deutsch 1997).

O Eh, potencial de óxido-redução, é uma medida da força eletromotriz da água expressa em volts, relacionada ao eletrodo padrão de hidrogênio, com Eh padronizado como potencial zero.

\subsubsection{Coleta de Amostras de Solo}

Em abril de 1999 foram coletadas 22 amostras de solo à jusante da área para caracterização da contaminação de manganês. Estas amostras foram coletadas através de trado manual de diâmetro de 4" (quatro polegadas), acondicionadas em frascos individuais e esterilizados e encaminhadas ao laboratório imediatamente após a coleta.

Em alguns pontos de amostragem foram coletadas amostras em três horizontes, com o intuito de se determinar a concentração e distribuição vertical do manganês. Estes horizontes foram definidos como "A, B e C", e correspondem respectivamente à profundidades $0,25,0,50$ e $0,75 \mathrm{~m}$. 


\subsubsection{Coleta de Amostras de Água}

Anterior a amostragem da água subterrânea, foi realizado o esgotamento dos poços de monitoramento, com retirada de toda a água de seu interior.

O sistema de coleta constitui-se na inserção de bailer de polietileno esterilizado e descartável, com diâmetro interno de $3 / 4$ polegadas.

Quando os parâmetros a serem analisados são metais, como é o caso deste estudo, é necessário se adotar procedimento para não superestimar ou subestimar o resultado das análises químicas.

A metodologia de amostragem tem como objetivo preservar o estado de valência dos metais dissolvidos na água subterrânea (Sracek, 1998). A filtragem das amostras foram realizadas utilizando-se filtro constituído por membrana em hester de celulose, de $0,45 \mu \mathrm{m}$ de poro, $47 \mathrm{~mm}$ de diâmetro, cor branca e lisa. Esta membrana foi colocada no interior de um holder adaptável a seringa. A filtragem foi realizada através de seringa

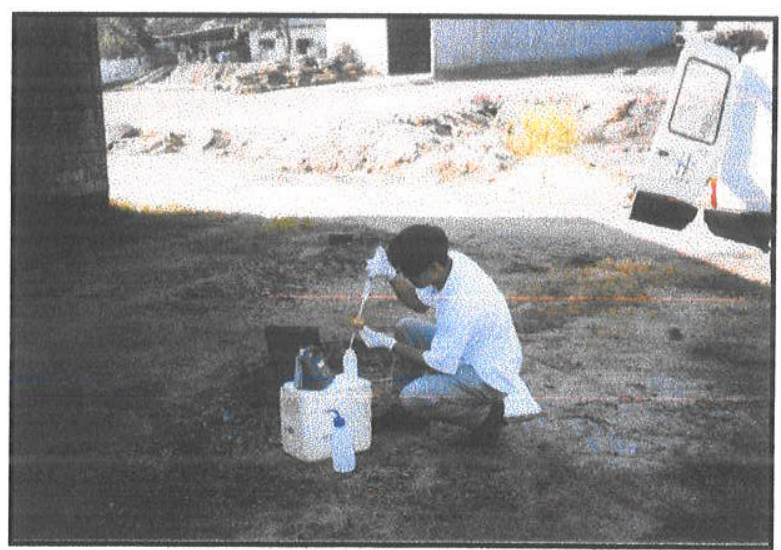

Foto 03 - Procedimento de amostragem da água subterrânea - filtragem da água esterilizada e descartável (Foto 03).

As amostras foram acondicionadas em frascos com capacidade volumétrica de $250 \mathrm{~mL}$, translúcido, de polietileno de baixa densidade com tampa rosqueável em polipropileno. Estas características conferem ao frasco maior resistência ao impacto, além do fato de possuir traços de metais extremamente baixos

Este procedimento de amostragem foi utilizado tanto para análise de cátions quanto para análise dos ânions. A única diferença, foi a acidificação das amostras para análise dos cátions, utilizando-se $\mathrm{HNO}_{3}$ (ácido nítrico) mantendo a amostra em meio ácido $(\mathrm{pH}<2)$, pois neste ponto de $\mathrm{pH}$ os minerais são solúveis e não se precipitarão. Para a análise de alcalinidade frascos individuais foram utilizados para análise em laboratório. Segundo Deutsch (1997), este procedimento possibilita que a calcita ou qualquer outro mineral carbonático, precipitado no frasco se redissolva durante a 
análise e todo o conteúdo de carbonato seja considerado na medição da alcalinidade.

Após a filtração, as amostras foram acondicionadas em caixa isopor e mantidas em baixa temperatura $\left(T<5^{\circ} \mathrm{C}\right)$ até a análise em laboratório. A refrigeração inibe processos biológicos que podem inibir a denitrificação caso a concentração de carbono orgânico presente na amostra seja suficiente para consumir o oxigênio disponível (Deutsh, 1997).

Amostra de água subterrânea em pontos da área alagadiça foram coletadas através de minipiezômetros (MPz) conforme metodologia descrita por Lee (1978). O MPz constitui em método de baixo custo e eficiente em locais com corpos d'água superficiais.

Foram efetuadas também coletas de água superficial (AS) para verificação das concentrações no córrego que corta a área.

\subsubsection{Tratamento dos dados}

As medidas de $\mathrm{pH}$ e Eh são dados importantes, uma vez que controlam a solubilidade de muitos minerais. Estes dados são importantes também para se determinar o campo de estabilidade de espécies dissolvidas na água subterrânea, como nos diagramas Eh-pH.

Segundo Brookins (1988), o diagrama Eh-pH para o Mn (sistema Mn-O-H), apresenta a maioria dos campos de estabilidade ocupados pelo $\mathrm{Mn}^{+2}$. Os óxidos e oxihidróxidos aparecem somente em $\mathrm{pH}$ alcalinos e altos valores de Eh. 


\subsubsection{Modelagem Hidrogeoquímica}

Avaliação do comportamento do manganês na água subterrânea foi feita através do programa WATEQ4F (Plummer et al., 1976).

O Wateq4f é um programa de modelagem hidrogeoquímica da U.S. Geological Survey que possibilita o cálculo da distribuição dos elementos, entre íons simples e complexos de metais. Este programa permite dividir as concentrações totais de espécies de redox utilizando-se da medida de Eh, calcular a pressão parcial de gases como a pressão de $\mathrm{CO}_{2}$ e os índices de saturação dos diferentes minerais para determinar se estes estão precipitados ou dissolvidos nas condições físico-químicas do aqüífero. 


\section{RESULTADOS OBTIDOS}

\subsection{Caracterização da Área de Estudo}

\subsubsection{Localização da Área}

A área de estudo localiza-se no município de Suzano, porção leste da Região Metropolitana de São Paulo, a $45 \mathrm{Km}$ da capital. A cidade de Suzano, com $184 \mathrm{Km}^{2}$ de área, está contornada pelos municípios de Mogi das Cruzes, Ribeirão Pires, Mauá, Ferraz de Vasconcelos, Poá e Itaquaquecetuba.

O acesso à área, a partir da cidade de São Paulo, pode ser feito pela Rodovia Anchieta (SP-150), seguida da Estrada Caminhos do Mar (SP-148) e posteriormente pela Rodovia Índio-Tibiriçá (SP-031), até o Bairro Palmeiras.

A área possui 1,57 ha e localiza-se à margem da Rodovia Índio-Tibiriçá, sendo limitada aos fundos pelo córrego Taiaçupeba Mirim. Este córrego deságua na barragem de Taiaçupeba originariamente contribuinte da bacia hidrográfica do Tietê. Na porção jusante, a área é cortada por uma estrada de ferro.

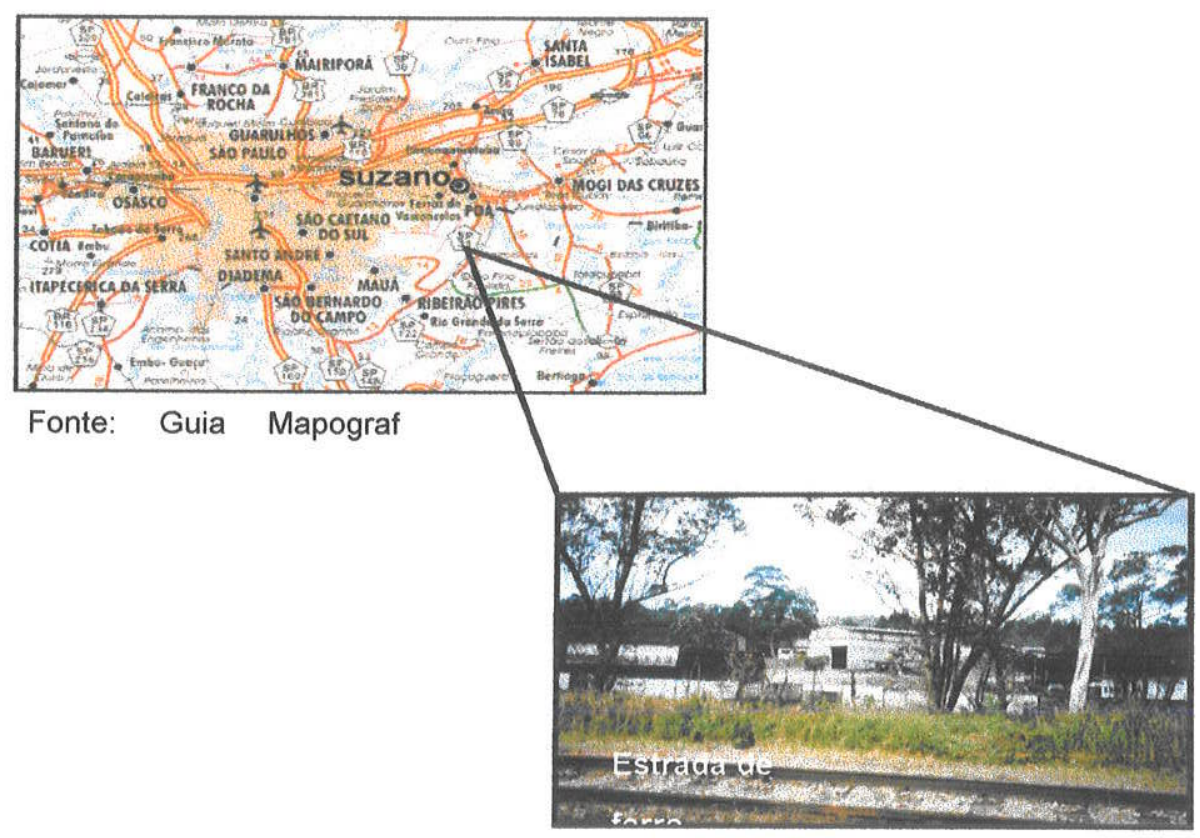

Figura 01 - Localização da área 


\subsubsection{Histórico da Contaminação}

A indústria química está em atividade no local desde 1980, tendo funcionado anteriormente como olaria por um período de aproximadamente dez anos,. Nesta época, o local possuía uma série de cavas para extração de argila utilizada na fabricação de materiais de construção.

A partir de 1991, com a construção de novas unidades da fábrica, iniciou-se a produção de compostos a base de manganês. Os rejeitos da produção, $\mathrm{MnSO}_{4}$, foram então enterrados em terreno vizinho aos limites da área (Figura 02).

Atualmente as instalações são utilizadas somente pela área comercial e estocagem de produtos químicos compostos por uma mistura de micronutrientes para preparação de adubos oriundos de uma outra unidade industrial.

Os rejeitos enterrados, constituídos basicamente por material argiloso e siltoso, constituem a mais importante fonte de contaminação da área estudada. Outra fonte, porém em menor escala, são os resíduos na forma de pó, liberados durante o manuseio do produto armazenado.

Na porção noroeste da área há uma lagoa (Foto 04) que era utilizada para disposição de resíduos líquidos de descarte na época que a área era utilizada no desenvolvimento de produtos químicos. Esta operação foi paralisada no mesmo ano de início, uma vez que, a produção destes compostos foi transferida para uma outra unidade.

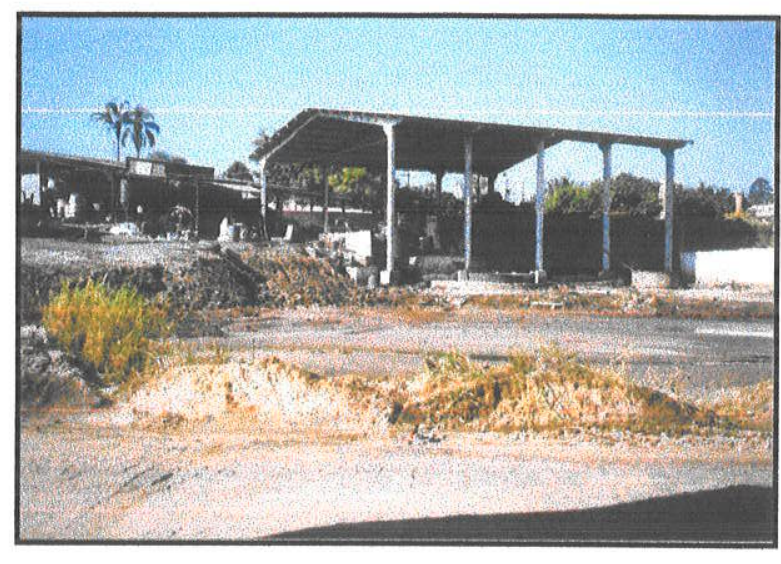

Foto 04 - Vista da lagoa 


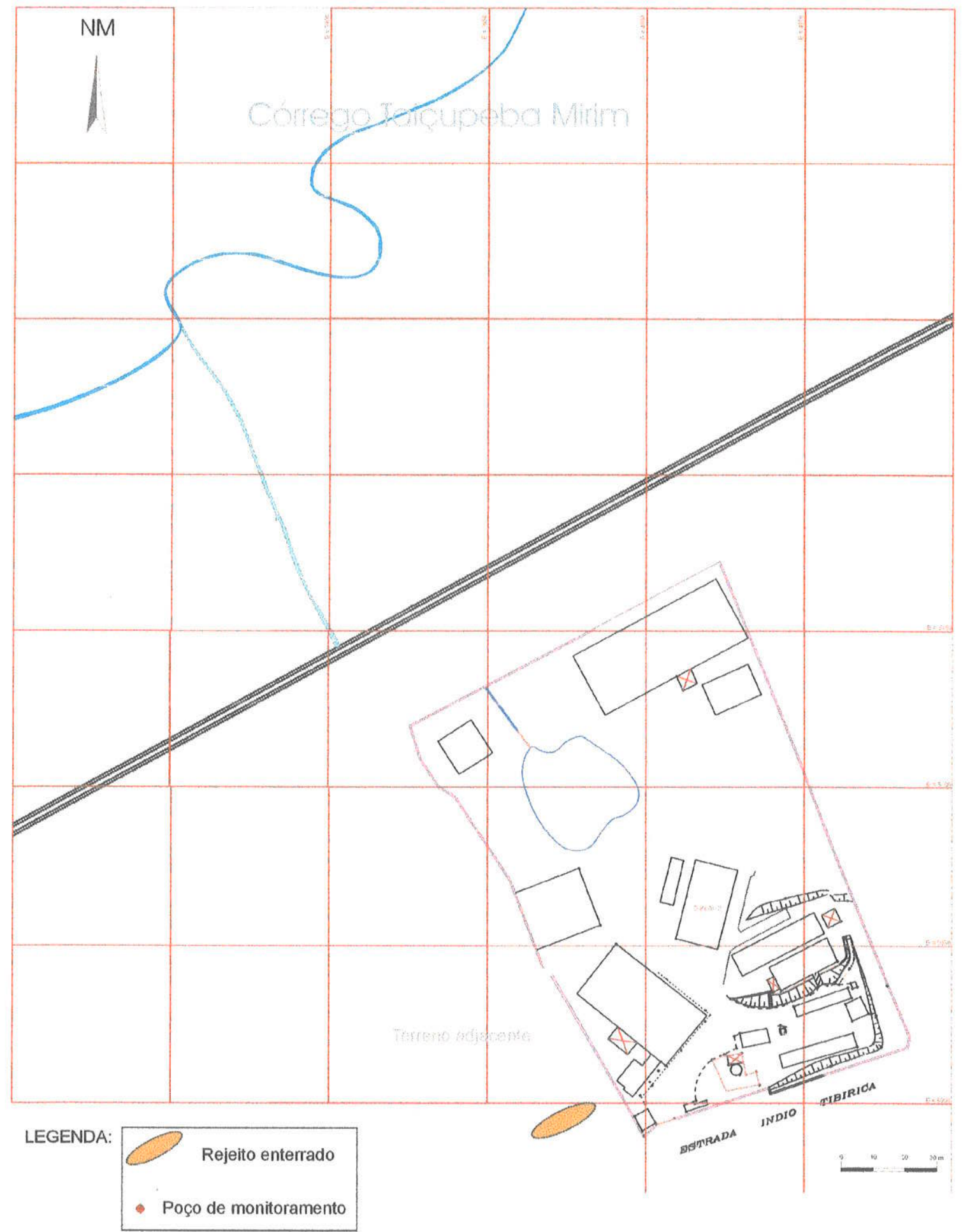

Figura 02 - Mapa com a localização aproximada do rejeito e edificações da área 


\subsubsection{Aspectos Climáticos}

Segundo Nimer (1977), a área apresenta temperaturas amenas com médias anuais entre 18 e $19^{\circ} \mathrm{C}$ e o clima é classificado como mesotérmico brando, do tipo superúmido sem seca.

De acordo com os dados do Plano Diretor do Município de Suzano (1991), as chuvas estão concentradas entre os meses de dezembro e fevereiro (precipitação acima de $1360 \mathrm{~mm}$ ). O período de seca é caracterizado nos outros meses (índice pluviométrico em torno de $30 \mathrm{~mm}$ ) sendo mais evidenciado no mês de junho.

\subsubsection{Uso e Ocupação do Solo}

O local em estudo situa-se em Área de Mananciais, no Vale do Rio Taiaçupeba, nas proximidades da Represa Billings. Por esses fatores ela se constitui numa Área de Proteção Ambiental (APA).

A Figura 03 apresenta a localização aproximada da área na região ocupada pela área de proteção de mananciais.

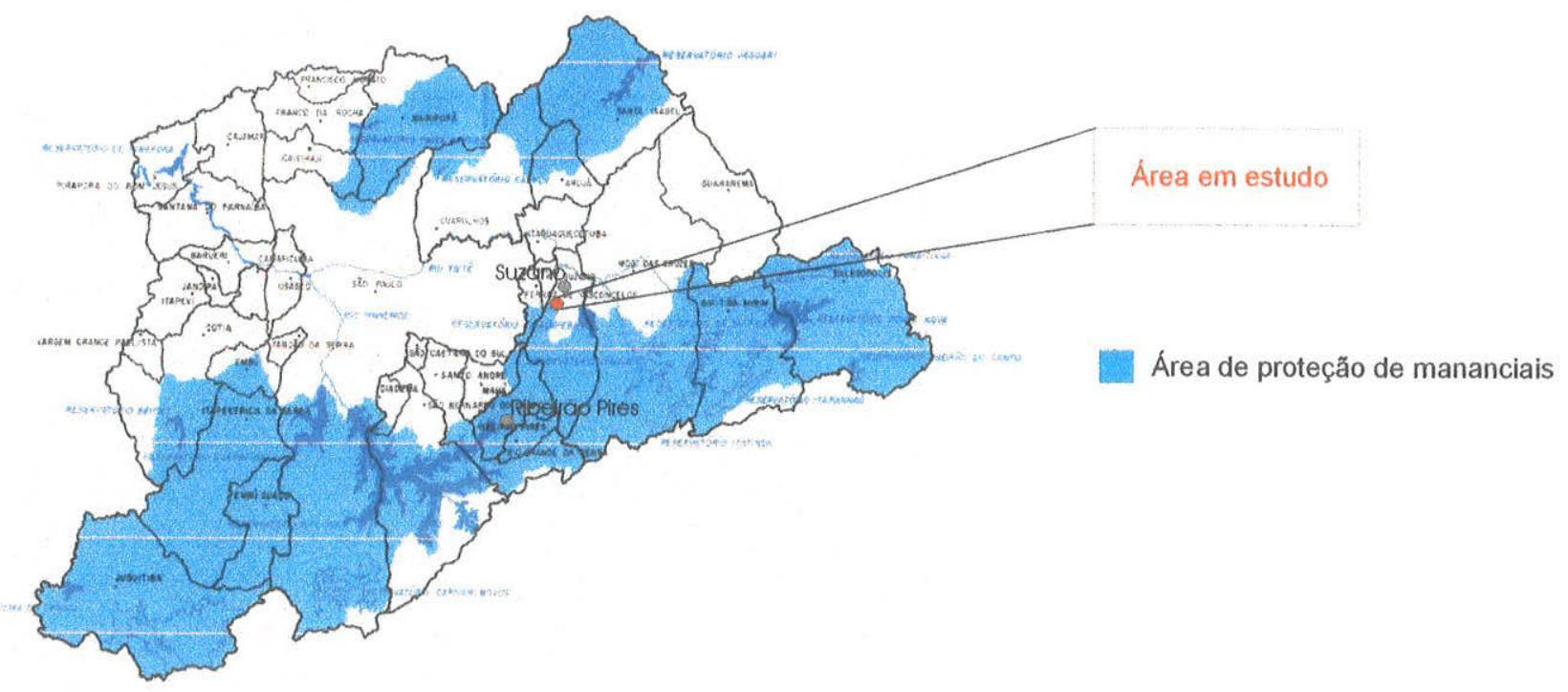

Fonte: SOS Mananciais - Governo do Estado de Săo Paulo

Figura 03 - Área de proteção de mananciais 
A região é pouco povoada e a pequena ocupação existente ocorreu principalmente ao longo da Rodovia Índio Tibiriçá. Predomina a atividade industrial, principalmente indústrias químicas de fertilizantes e algumas olarias. Em alguns locais são desenvolvidas culturas de subsistência. 


\subsubsection{Geologia Regional e Local}

Segundo a CPRM (1990), a área é caracterizada pela presença de rochas pertencentes ao Complexo Cristalino de idade Pré-Cambriana, sedimentos da Bacia de São Paulo e sedimentos quaternários relacionados às várzeas dos rios atuais.

Do topo para a base, seguindo a estratigrafia, encontramos primeiramente uma camada de sedimentos quaternários associados aos aluviões delgados e relativamente extensos dispostos ao longo das várzeas atuais e aos colúvios (Melo et al., 1986; Melo et al., 1987 in CPRM, 1990).

Sedimentos terciários ocupam a camada estratigráfica intermediária, constituída por arenitos e pelitos com intercalação de conglomerados, correlatos à Bacia de São Paulo.

As principais litologias encontradas são os arenitos finos localmente conglomeráticos com estratificações cruzadas acanaladas, siltitos e argilitos maciços, siltitos finos localmente conglomeráticos e com estratificação cruzada acanalada.

A base da estratigrafia é formada pelo embasamento cristalino representado por granitos sintectônicos e pós-tectônicos, migmatitos e gnaisses graníticos, micaxistos e meta-arenitos pertencentes ao Complexo Embu.

A geologia local é constituída por cobertura aluvionar, composta por argilas de coloração cinza-escura a preta, argilas arenosas a siltosas de coloração amarelada e cinza.

Não foram identificados na área, afloramentos que compõem o embasamento. Durante as sondagens observaram-se, em determinados pontos, perfil de alteração de rochas metamórficas e camada de aterro na porção a montante. Este perfil constitui-se basicamente de material argilo-arenoso a areno-siltoso. Intercalados neste material foram encontrados grãos de feldspato caulinizados. 


\subsection{Caracterização Hidrogeológica}

A área de estudo apresenta ao fundo uma drenagem que forma uma extensa planície aluvionar, com água aflorante em quase sua totalidade. A porção à montante, onde está localizada a fonte de contaminação é caracterizada por camadas de aterro e solos residuais. Esta porção corresponde à área de recarga do aqüífero sendo que a existência desta zona aluvionar proporciona o rebaixamento das linhas potenciométricas funcionando assim como zona de descarga das águas do aqüífero, representando a área alagadiça anteriormente citada.

O mapa de fluxo esperado apresenta linhas equipotenciais (elevação da carga hidráulica do aqüífero) que devem ser aproximadamente paralelas às bordas do limite da zona aluvionar, acompanhando aproximadamente as curvas topográficas do terreno.

A área alagadiça corresponde à própria superfície do aqüífero raso naquele local, uma vez que a água subterrânea é aflorante Esta situação pressupõe um fluxo de água subterrânea que se move dos locais topograficamente mais elevados para os locais mais baixos, que correspondem aos locais de carga hidráulica mais elevada para locais de menor carga hidráulica.

Considerando 0 modelo préestabelecido, a área alagadiça (Foto 05) deve estar contaminada uma vez que o transporte pela água subterrânea ocorre preferencialmente das áreas mais externas para esta área.

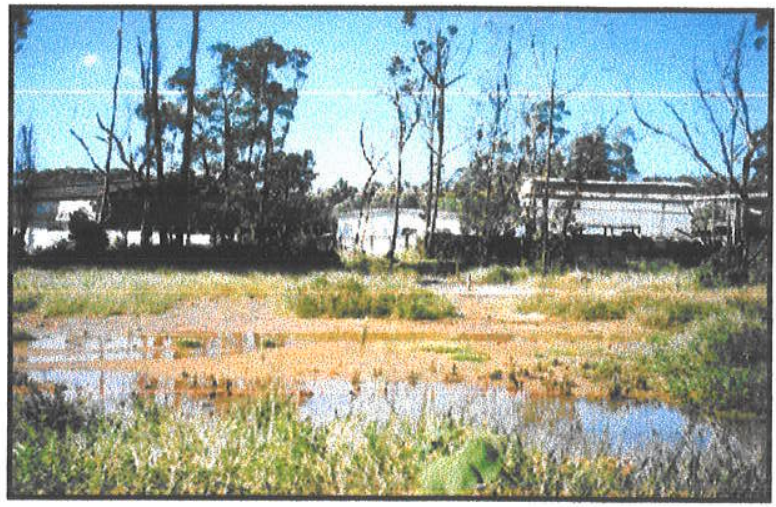

Foto 05 - Área alagadiça a jusante

O processo de lixiviação da fonte de contaminação enterrada em terreno adjacente a área de estudos e considerando-se apenas o processo de fluxo das águas subterrâneas, é o principal vetor de contaminação da área a jusante.

A contaminação das águas na área alagadiça é a própria contaminação da água subterrânea das áreas fontes, uma vez que a água subterrânea é aflorante. 
Os Poços de Monitoramento (PMs), baseados no modelo hidrogeológico conceitual, foram locados de forma a interceptar a pluma de contaminação e mapear o seu contorno.

A Figura 04 apresenta um esquema do modelo hidrogeológico conceitual estabelecido para a área em estudo.

MODELO HIDROGEOLÓGICO CONCEITUAL

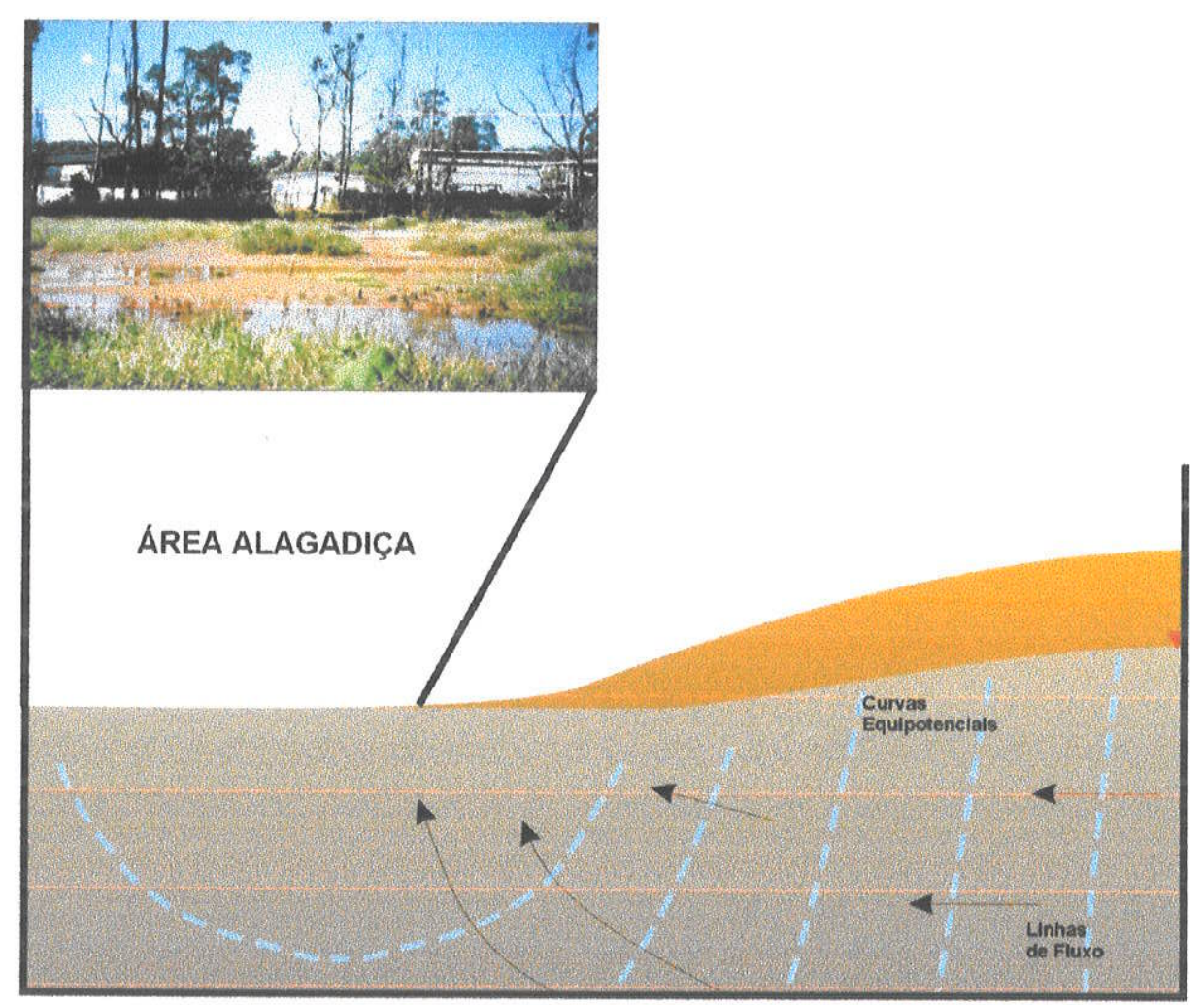

Figura 04 - Modelo hidrogeológico para a área em estudo 


\subsubsection{Poços de Monitoramento}

O aqüifero livre apresenta uma zona não saturada com espessura variável entre 0,3 m (PM-09) e 5,5 m (PM-12). Esse pacote com alta porosidade de retenção se sobrepõe à zona saturada, predominantemente constituída por solo residual, caracterizado por sedimentos mais arenosos de compacidade média, mais condutivo e menos poroso.

A profundidade média dos poços instalados na área foi de $3,0 \mathrm{~m}$ sendo o poço mais profundo, localizado a montante de $7,0 \mathrm{~m}$. (PM-12). Vale ressaltar que não foi possível a instalação de poços mais profundos, limitada pela litologia impenetrável ao método de perfuração utilizado (trado manual).

A Figura 05 apresenta o mapa de localização dos poços e o Apêndicel, os perfis construtivos destes PMs instalados 


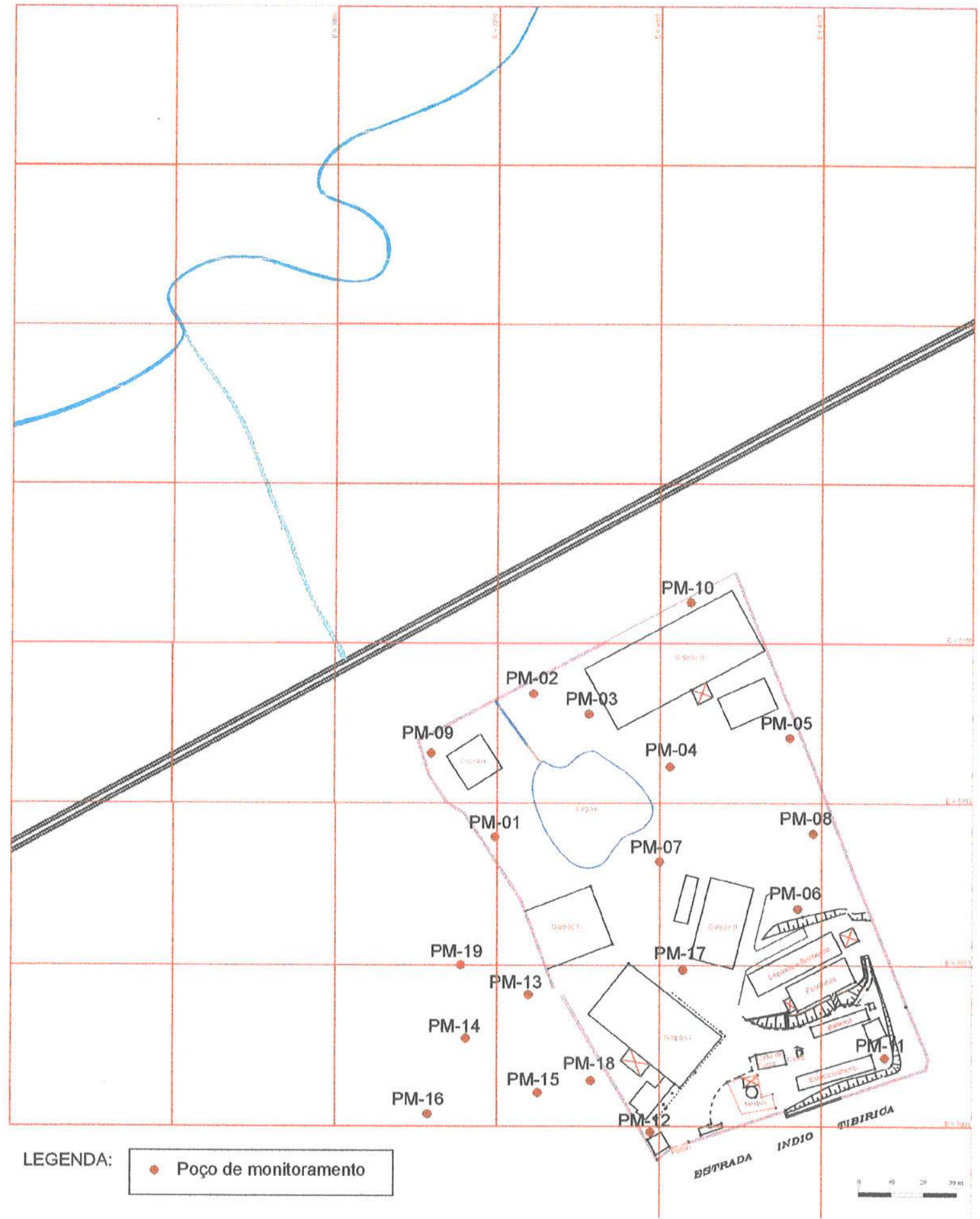

Figura 05 - Mapa de localização dos poços 


\subsubsection{Testes de condutividade hidráulica}

Foram efetuados quatro slug tests nos PMs 10, 11, 13 e 17 em agosto de 1998. Estes poços representam cada porção da área, situados à jusante, montante, terreno adjacente a sudoeste e porção central da área, respectivamente.

Apesar da heterogeneidade do aqǘfero, o meio foi considerado, para a realização destes testes, como sendo homogêneo, isotrópico e infinito apresentando tempos uniformes de respostas da carga hidráulica.

Os valores de condutividade hidráulica obtidos nestes testes encontram-se na Tabela 02:

Tabela 02 - Resultados dos Slug Tests

\begin{tabular}{|c|c|}
\hline POÇO & Condutividade Hidráulica $(\mathrm{cm} / \mathrm{s})$ \\
\hline PM-10 & $2,14 \times 10^{-5}$ \\
\hline PM-11 & $4,28 \times 10^{-5}$ \\
\hline PM-13 & $3,28 \times 10^{-5}$ \\
\hline PM-17 & $2,26 \times 10^{-5}$ \\
\hline
\end{tabular}

A Figura 06 apresenta os gráficos obtidos no tratamento dos dados dos ensaios realizado. 

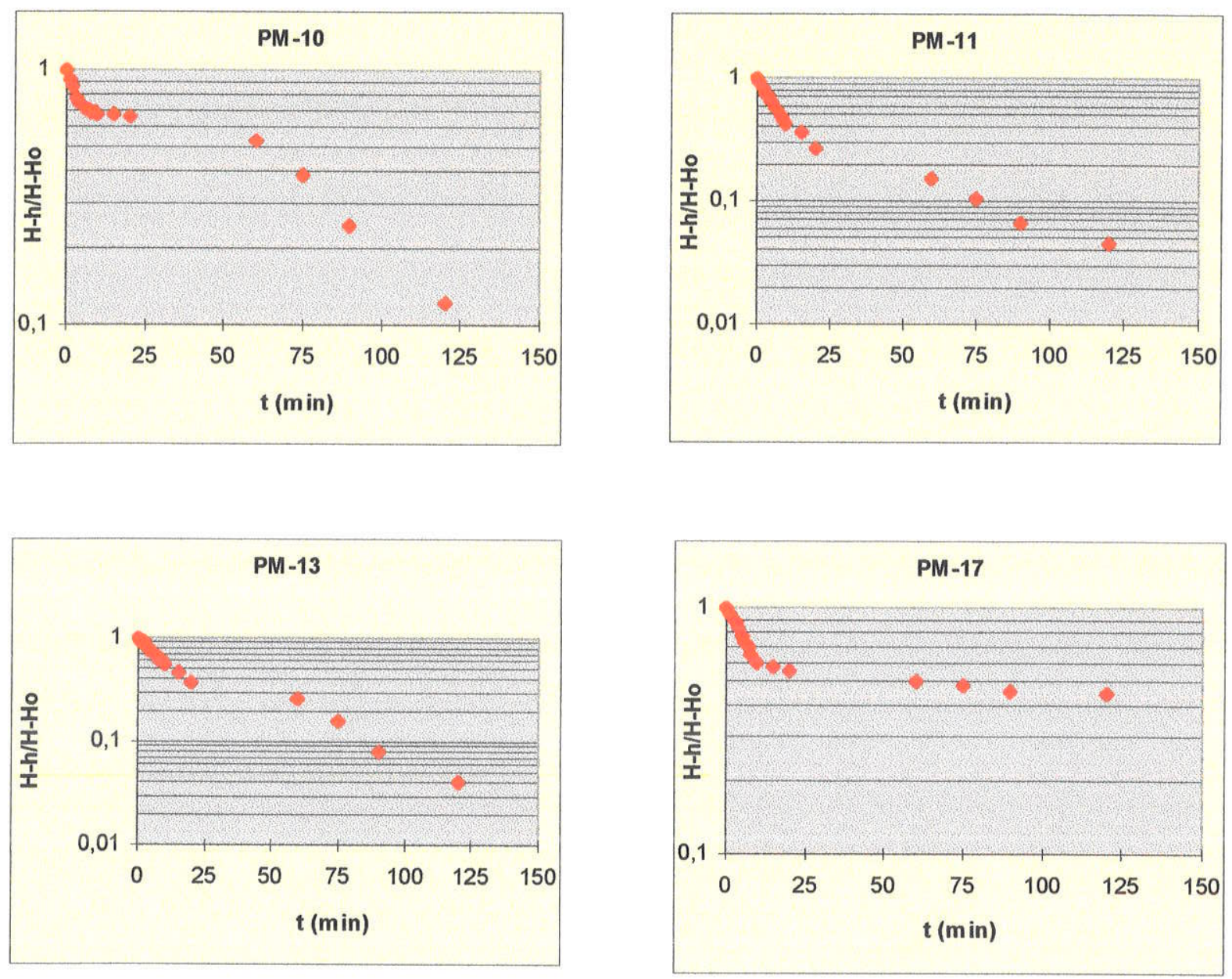

Figura 06 - Slug tests realizados

Não houve variação significativa nas condutividades hidráulicas obtidas, todas permanecendo em uma mesma ordem de grandeza. A maior condutividade foi verificada no PM-11 ( $\left.\mathrm{K}=4,28 \times 10^{-5} \mathrm{~cm} / \mathrm{s}\right)$, na porção à montante da área e a menor no $\mathrm{PM}-10\left(\mathrm{~K}=2,14 \times 10^{-5} \mathrm{~cm} / \mathrm{s}\right)$ na porção à jusante. O valor médio da condutividade hidráulica calculado foi de $2,99 \times 10^{-5} \mathrm{~cm} / \mathrm{s}$. 


\subsubsection{Levantamento Planialtimétrico}

O levantamento planialtimétrico possibilitou a confecção de planta topográfica da área de estudo. Cotas arbitrárias dos PMs e de outras referências são importantes ferramentas para a elaboração do mapa potenciométrico.

A Figura 07 apresenta a localização dos poços com suas respectivas cotas altimétricas.

A Tabela 03, a seguir, apresenta as cotas altimétricas obtidas para todos os poços de monitoramento:

Tabela 03 - Cotas Altimétricas

\begin{tabular}{|c|c|}
\hline Poço & Cota (m) \\
\hline PM-01 & 91,06 \\
\hline PM-02 & 90,19 \\
\hline PM-03 & 90,96 \\
\hline PM-04 & 90,96 \\
\hline PM-05 & 92,35 \\
\hline PM-06 & 95,30 \\
\hline PM-07 & 93,46 \\
\hline PM-08 & 93,35 \\
\hline PM-09 & 90,68 \\
\hline PM-10 & 90,99 \\
\hline PM-11 & 101,21 \\
\hline PM-12 & 99,84 \\
\hline PM-13 & 94,35 \\
\hline PM-14 & 94,37 \\
\hline PM-15 & 95,57 \\
\hline PM-16 & 95,23 \\
\hline PM-17 & 96,27 \\
\hline PM-18 & 96,68 \\
\hline PM-19 & 94,13 \\
\hline & \\
\hline & \\
\hline & \\
\hline & 9 \\
\hline & 9 \\
\hline & 9 \\
\hline
\end{tabular}




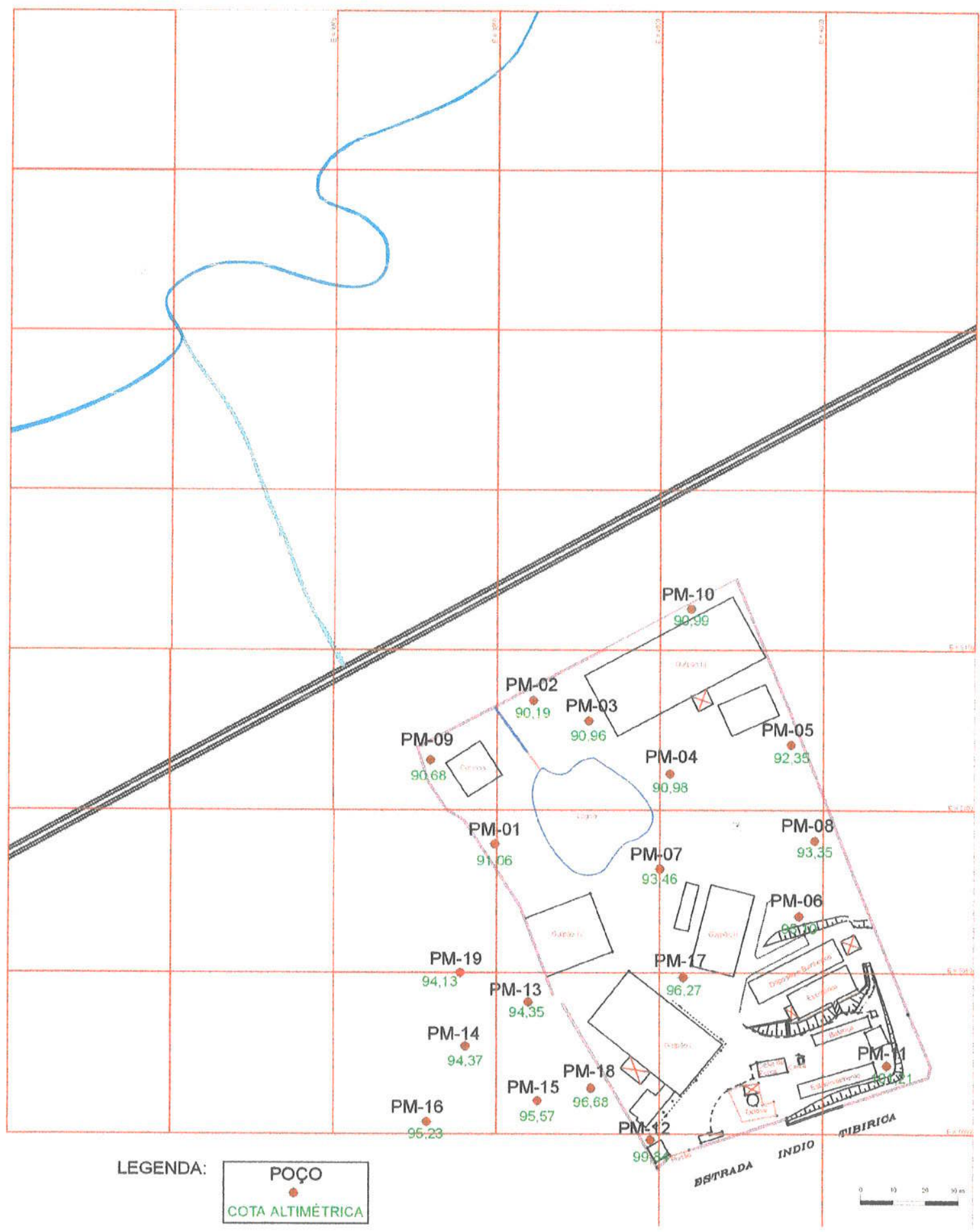

Figura 07 - Mapa representando as cotas altimétricas 


\subsubsection{Potenciometria}

O monitoramento dos níveis d'água nos poços foi feito através de duas etapas de campo nos períodos de outubro/1998 e abril/1999. Estes valores seguem praticamente $O$ declive da superfície. Através do levantamento planialtimétrico dos poços e das medições dos níveis d'água, foram elaborados dois mapas potenciométricos (Figuras 8 e 9 ).

As Figuras 8 e 9 ilustram pequenas variações localizadas quanto ao comportamento das linhas equipotenciais. Tais modificações, no entanto, não modificaram o modelo hidrogeológico pré-estabelecido para a área. As direções de fluxo são de SE para NW, ou seja, da Rodovia Indio Tibiriçá à área alagadiça, considerada zona de descarga. 


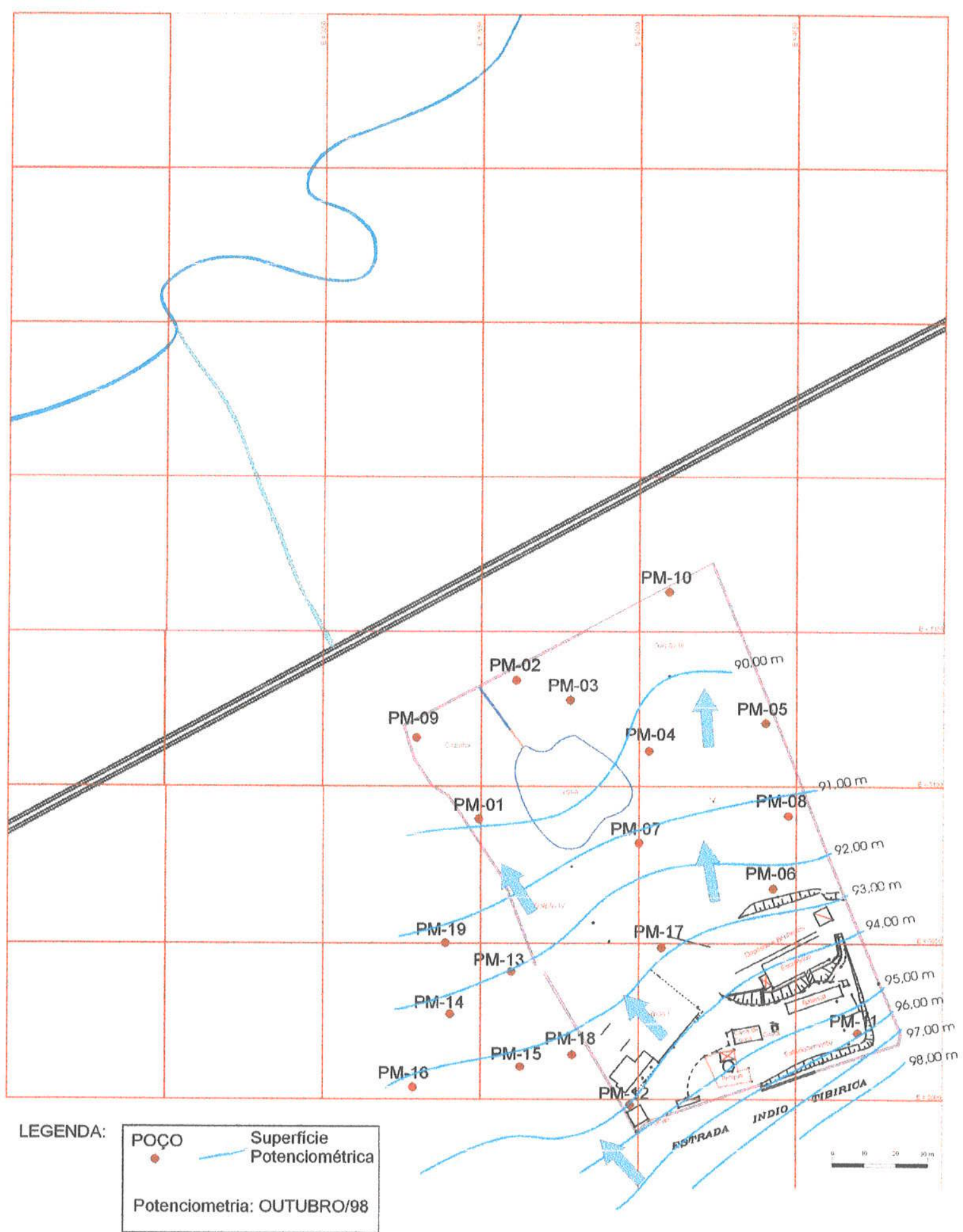

Figura 08 - Mapa potenciométrico (outubro/98) 


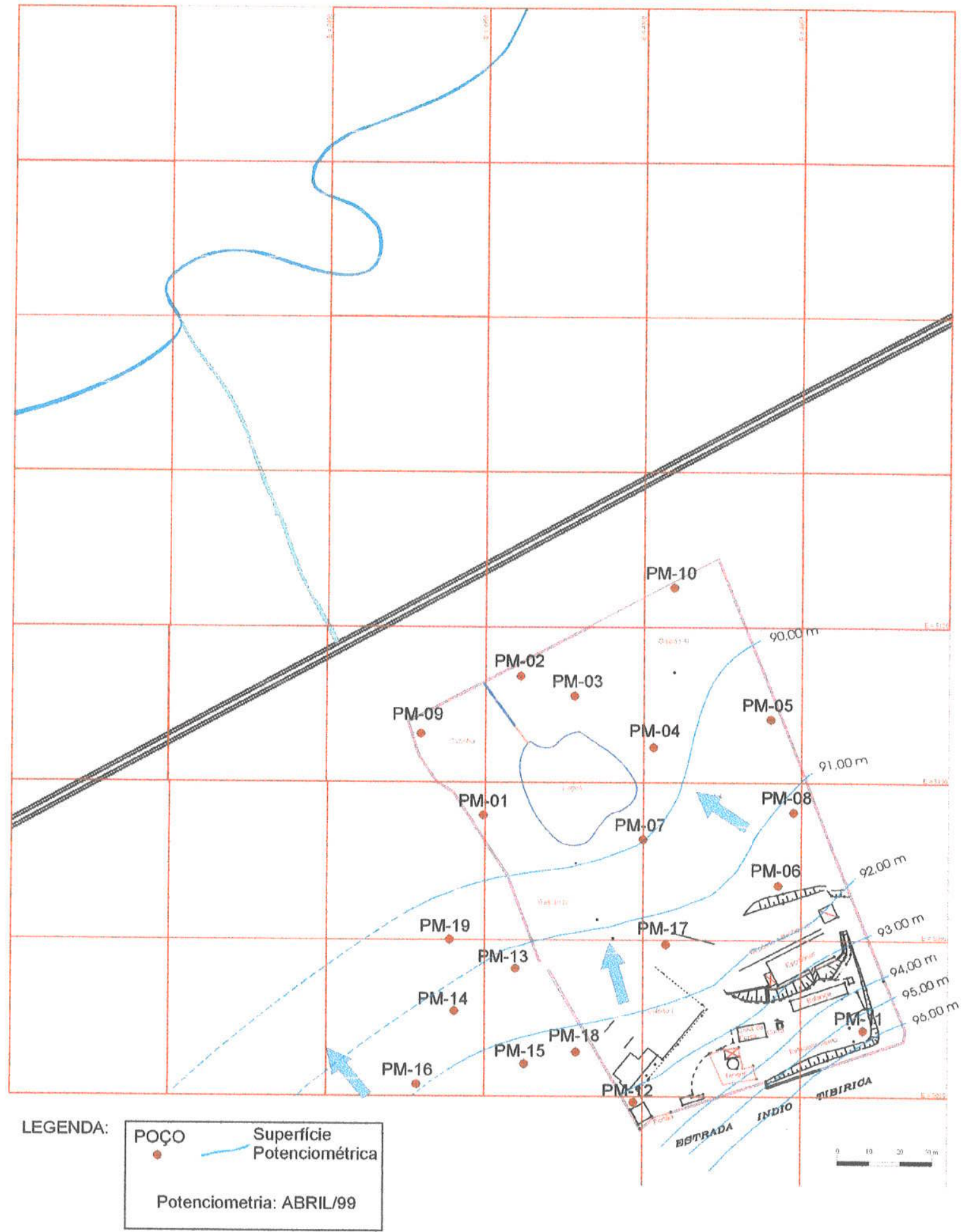

Figura 09 - Mapa potenciométrico (abril/99) 


\subsubsection{Velocidade da Água Subterrânea}

A partir do mapa potenciométrico foi obtido o gradiente hidráulico da área em estudo e a partir da descrição granulométrica das sondagens foram estimadas a porosidade efetiva (Fetter, 1988), conforme apresentado na Tabela 04.

Tabela 04 - Dados hidrogeológicos

\begin{tabular}{|c|c|c|c|}
\hline Dados hidrogeológicos & Mínimo & Máximo & Média \\
\hline Condutividade Hidráulica $(K)$ & $2,14 \times 10^{-5} \mathrm{~cm} / \mathrm{s}$ & $4,28 \times 10^{-5} \mathrm{~cm} / \mathrm{s}$ & $2,99 \times 10^{-5} \mathrm{~cm} / \mathrm{s}$ \\
\hline Gradiente Hidráulico $(i)$ & $3,4 \%$ & $14 \%$ & $8,7 \%$ \\
\hline Porosidade Efetiva para fluxo $\left(\mathrm{n}_{\mathrm{ef}}\right)$ & $19 \%$ & $3 \%$ & $18 \%$ \\
\hline Velocidade Linear & $0,33 \mathrm{~cm} / \mathrm{dia}$ & $17,26 \mathrm{~cm} / \mathrm{dia}$ & $1,25 \mathrm{~cm} /$ dia \\
\hline
\end{tabular}

A velocidade máxima obtida da água subterrânea na área de estudos, obtida a través de uma extensão da Lei de Darcy, foi de $17,28 \mathrm{~cm} / \mathrm{dia}$. Estes cálculos não consideraram o transporte de contaminantes pela água, uma vez que neste caso, deverá ser levado em consideração os mecanismos de retardamento e não apenas o transporte advectivo.

As velocidades mínima e média obtidas foram respectivamente de 0,33 e $1,25 \mathrm{~cm} /$ dia. 


\subsection{Caracterização da Contaminação}

\subsubsection{Parâmetros físico-químicos}

Os valores de Eh e pH obtidos em campo e realizados em dois eventos de monitoramento estão apresentados nas Tabelas 05 e 06.

Vale ressaltar que as medidas de Eh foram corrigidos para o eletrodo de hidrogênio utilizando-se o fator de correção $0,25 \mathrm{~V}$.

Tabela 05 - Valores de pH e Eh obtidos em outubro/98 nos PMs

\begin{tabular}{|c|c|c|}
\hline Pogos & pH & Eh (V) \\
\hline PM-01 & 6,3 & 0,51 \\
\hline PM-02 & 4,7 & 0,63 \\
\hline PM-03 & 4,4 & 0,60 \\
\hline PM-04 & 4,5 & 0,71 \\
\hline PM-05 & 5,2 & 0,75 \\
\hline PM-06 & 6,1 & 0,65 \\
\hline PM-07 & 4,3 & 0,76 \\
\hline PM-08 & 5,0 & 0,79 \\
\hline PM-09 & 3,30 & 0,77 \\
\hline PM-10 & 5,0 & 0,78 \\
\hline
\end{tabular}

\begin{tabular}{|c|c|c|}
\hline Pogos & $\mathrm{PH}$ & Eh $(\mathrm{V})$ \\
\hline $\mathrm{PM}-11$ & 5,56 & 0,70 \\
\hline $\mathrm{PM}-12$ & 5,9 & 0,53 \\
\hline $\mathrm{PM}-13$ & 4,7 & 0,73 \\
\hline $\mathrm{PM}-14$ & 4,3 & 0,74 \\
\hline $\mathrm{PM}-15$ & 5,1 & 0,63 \\
\hline $\mathrm{PM}-16$ & 5,5 & 0,66 \\
\hline $\mathrm{PM}-17$ & 5,0 & 0,73 \\
\hline $\mathrm{PM}-18$ & 4,6 & 0,75 \\
\hline $\mathrm{PM}-19$ & 5,7 & 0,65 \\
\hline
\end{tabular}

Os valores de Eh obtidos da água subterrânea no monitoramento realizado em outubro/98 estão no intervalo 0,51 a $0,79 \mathrm{~V}$ e os valores de $\mathrm{pH}$ no intervalo de 3,30 a 6,30 . 
Tabela 06 - Valores de pH e Eh obtidos em abril/99 nos PMs, na área alagadiça e água superficial

\begin{tabular}{|c|c|c|c|c|c|}
\hline Poços & phI & Eh $(V)$ & dentificaçăo & $\mathrm{pH}$ & $\operatorname{Eh}(\mathrm{V})$ \\
\hline PM-01 & 6,43 & 0,49 & MPz-01 & 5,74 & 0,327 \\
\hline PMO3 & 4,8 & 0,48 & $\mathrm{MPz} \cdot 02$ & 5,62 & 0,312 \\
\hline PM-06 & 5,61 & 0,55 & MPz-03 & 6,36 & 0,231 \\
\hline PM.07 & 5,83 & 0,558 & $M P=-04$ & 6,08 & 0,268 \\
\hline PM-08 & 6,25 & 0,425 & MPz-05 & 6,61 & 0,218 \\
\hline PM-09 & 3,85 & 0,628 & AS-1 & 6.94 & 0,287 \\
\hline PM-10 & 5,68 & 0,498 & AS-II & 6,92 & 0,371 \\
\hline PM-11 & 5,46 & 0,597 & AS-11 a & 6,83 & 0.456 \\
\hline$P M-12$ & 6,24 & 0,55 & AS- $1111 \mathrm{~b}$ & 6,49 & 0,482 \\
\hline PM-13 & 4,35 & 0,562 & AS IV & 6,43 & 0,446 \\
\hline PM-14 & 6,86 & 0,308 & AS-V & 6,38 & 0,446 \\
\hline PM-15 & 4,26 & 0,592 & AS-VI & 6,27 & 0,454 \\
\hline PM-19 & 6,25 & 0,416 & & & \\
\hline
\end{tabular}

Os valores de Eh obtidos no monitoramento realizado em abril/99 se encontram no intervalo de 0,218 e 0,628 $\mathrm{V}$ e os valores de $\mathrm{pH}$ no intervalo de 3,85 a 6,94. 


\subsubsection{Resultados Analíticos e Interpretação}

As variações nos comportamentos de diversos parâmetros químicos foram observadas através de duas campanhas de amostragem compreendidas nos períodos de outubro/98 e abril/99, totalizando 19 análises na primeira campanha e 25 análises na segunda..

\section{a) PRIMEIRO EVENTO (outubro/98)}

Os parâmetros analisados nesta campanha de amostragem foram: sódio, potássio, cálcio, magnésio, ferro, manganês, cobre, chumbo, zinco, cobalto, estrôncio, fluoreto, cloreto, sulfato, hidrogenocarbonato e nitrato. Os resultados analíticos estão ilustrados no Apêndice II.

A Tabela 05 apresenta os resultados das concentrações de manganês e sulfato, principais alvos deste estudo.

Tabela 07 - Resumo das concentrações de manganês e sulfato ( $\mathrm{mg} / \mathrm{L}$ )

\begin{tabular}{|c|c|c|}
\hline Pogos & Manganes & Sulfato \\
\hline PM-01 & 3,80 & 100,00 \\
\hline PM-02 & 430,00 & 230,00 \\
\hline PM-03 & 860,00 & 3870,00 \\
\hline PM-04 & 190,00 & 1800,00 \\
\hline PM-05 & 89,00 & 90,00 \\
\hline PM-06 & 15,20 & 230,00 \\
\hline PM-07 & 1700,00 & 4780,00 \\
\hline PM-08 & 26,00 & 160,00 \\
\hline PM-09 & 940,00 & 6330,00 \\
\hline PM- 10 & 152,00 & 700,00 \\
\hline
\end{tabular}

\begin{tabular}{|c|c|c|}
\hline Pogos & Manganes & Sulfato \\
\hline PM-11 & $<0,1$ & $<5$ \\
\hline PM-12 & 13,40 & $<6$ \\
\hline PM-13 & 840,00 & 1500,00 \\
\hline PM-14 & 450,00 & 400,00 \\
\hline PM-15 & 1000,00 & 2060,00 \\
\hline PM-16 & 2,00 & $, 150,00$ \\
\hline$P M-17$ & 380,00 & 700,00 \\
\hline$P M-18$ & 260,00 & 1095,00 \\
\hline$P M-19$ & 6800,00 & 14280,00 \\
\hline
\end{tabular}

Comparando-se as concentrações de manganês e sulfato dos PMs nota-se que os resultados obtidos estão acima dos padrões estabelecidos pela Portaria 1.469 do Ministério da Saúde (2001), que estabelece como padrão de potabilidade para o consumo humano, $0,1 \mathrm{mg} / \mathrm{L}$ para o manganês e $250 \mathrm{mg} / \mathrm{L}$ para o sulfato. As Figuras 10 e 11 apresentam a pluma de contaminação para estes compostos. 


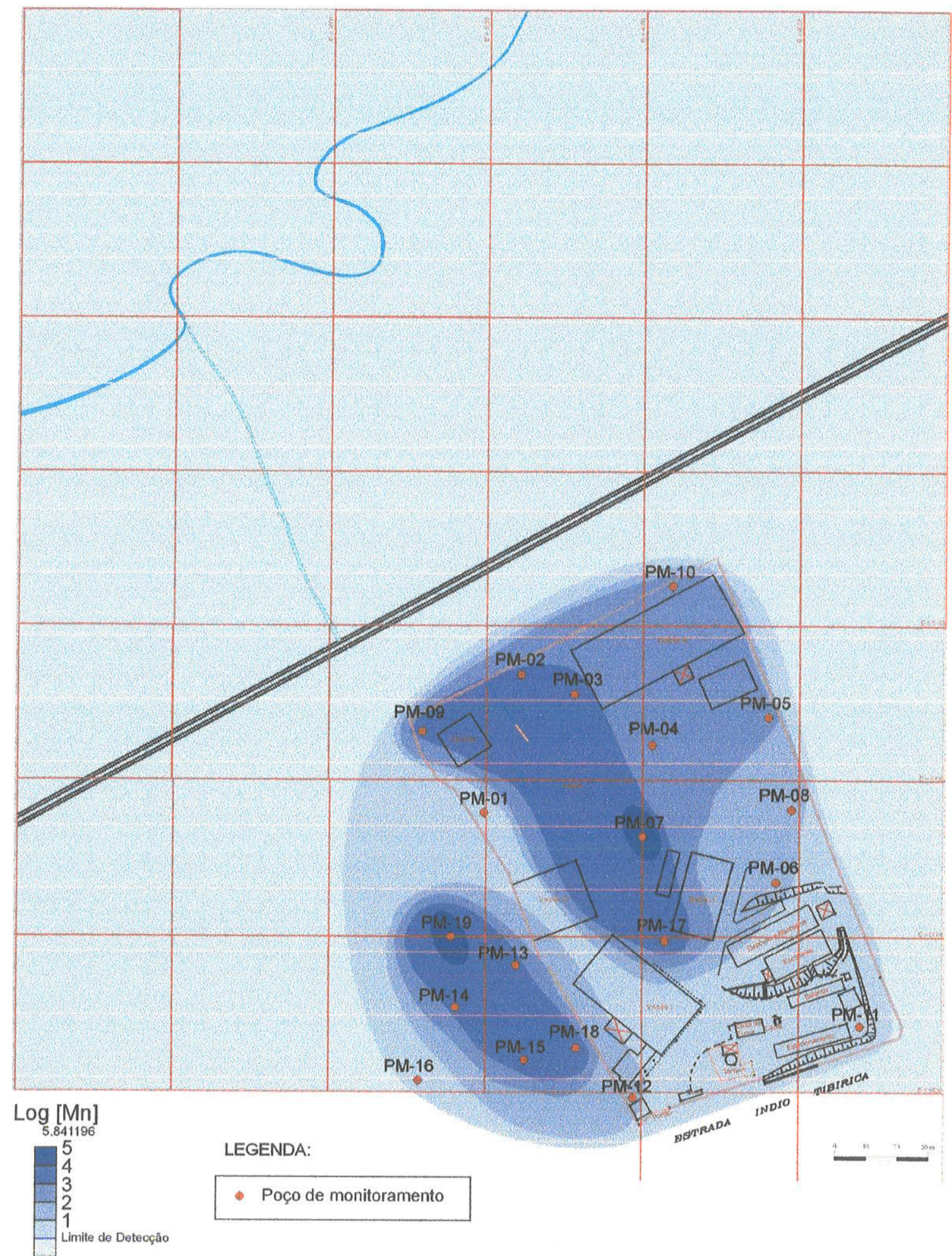

Figura 10 - Pluma de contaminação para manganês (outubro/98) 


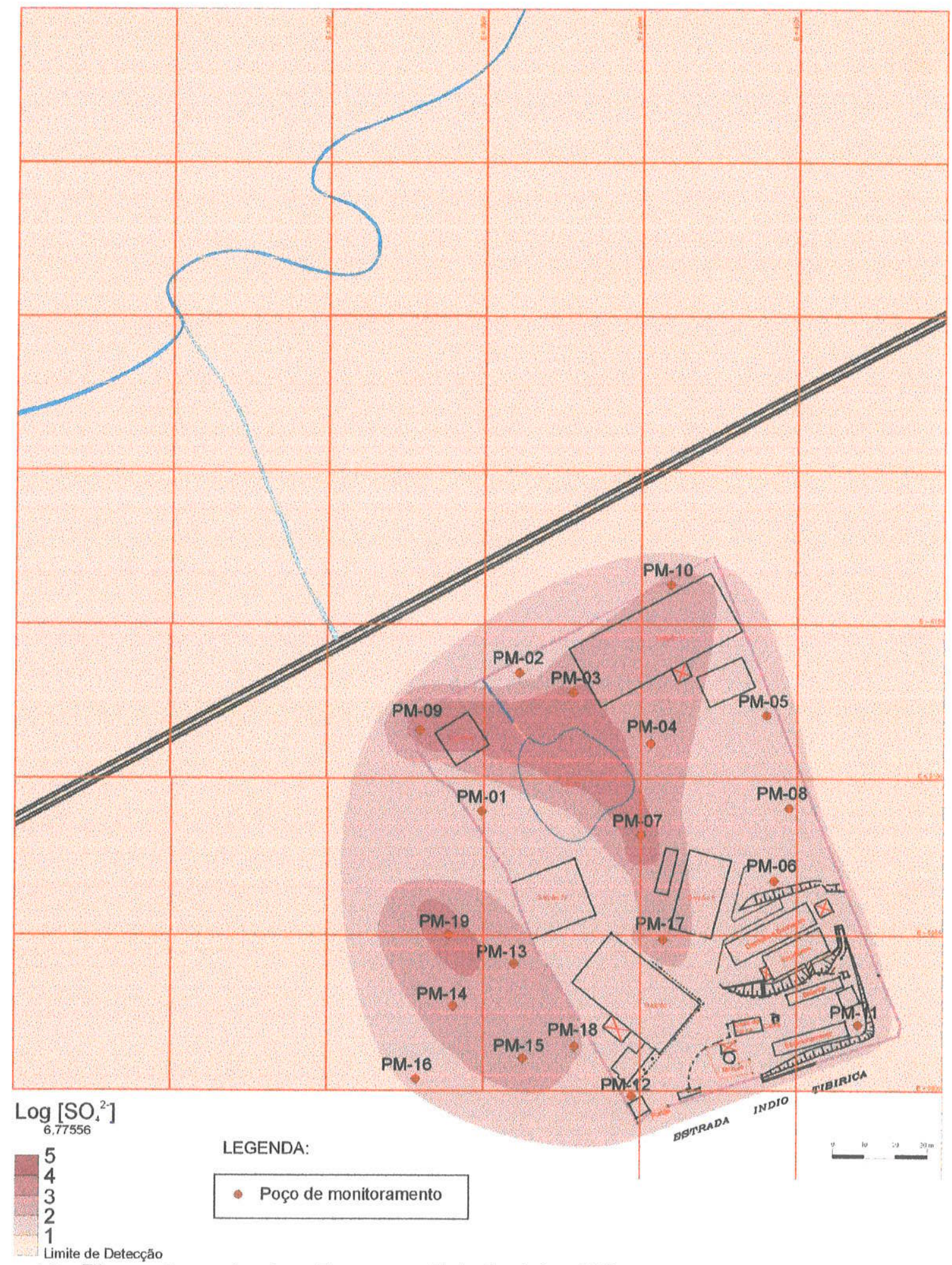

Figura 11 - Pluma de contaminação para sulfato (outubro/98) 
De acordo com a Figura 10, as elevadas concentrações de manganês foram identificadas principalmente nos poços PMs $02,03,07,09,13,15$, e 19, este último atingindo valor de $6.800 \mathrm{mg} / \mathrm{L}$.

Os valores de $\mathrm{EH}$ e pH, plotados no diagrama de equilíbrio Eh-pH (sistema Mn$\mathrm{O}-\mathrm{H}$ ), mostraram que os pontos amostrados estão contidos no campo de estabilidade ocupado pelo $\mathrm{Mn}^{2+}$. Isto indicou que o manganês encontra-se dissolvido na água subterrânea (Figura 12).

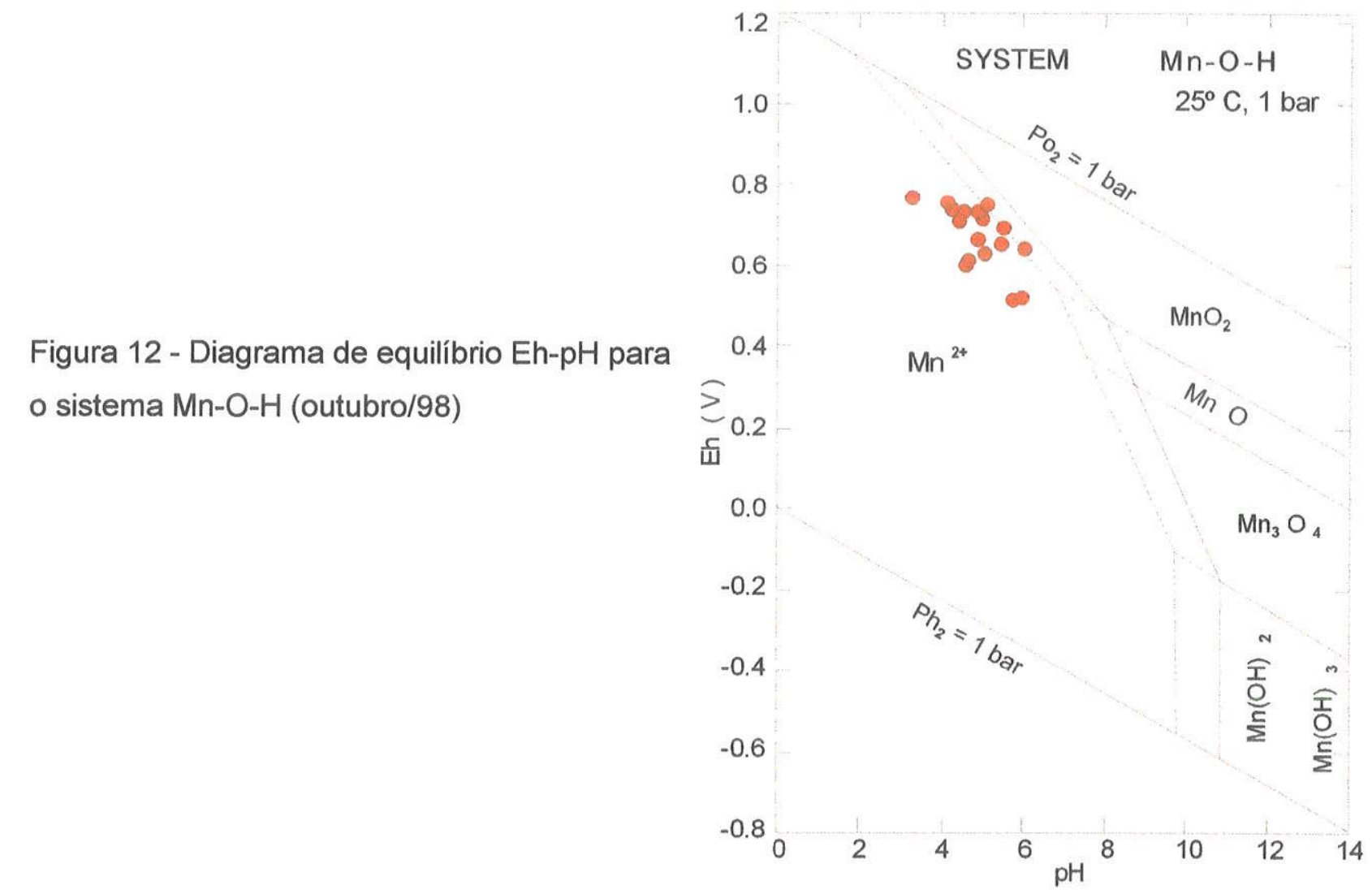

Da mesma forma que o manganês, altas concentrações de sulfato foram constatadas principalmente nos PMs $03,07,09,13,15,18$ e 19, cuja concentração máxima foi de $14.280 \mathrm{mg} / \mathrm{L}$, correspondente à porção oeste da área e relacionada ao local de disposição de resíduos posteriormente recobertos por solo (Figura 11).

O valor de background da água subterrânea, considerado na área, é representado pelo poço PM-11, uma vez que as concentrações de manganês e sulfato foram menores que os limites de detecção do aparelho. 
As concentrações desses dois elementos na fábrica, representados pelos PMs 06, 07, 08 e 17, encontram-se elevadas mesmo à montante da antiga lagoa de disposição. O PM-07 apresenta concentrações de manganês e sulfato iguais a $1.700 \mathrm{mg} / \mathrm{L}$ e $4.780 \mathrm{mg} / \mathrm{L}$, respectivamente. No entanto não houve aumento das concentrações para esses elementos à jusante da antiga lagoa de disposição conforme verificado nos PMs 03, 09 e 10.

Desta forma, significantes contribuições para a contaminação provêm da área de disposição de resíduos posteriormente recobertos por solo bem como da área de manipulação da fábrica à montante da antiga lagoa. 


\section{b) SEGUNDO EVENTO (abril/99)}

Esta campanha serviu como complementação à primeira realizada em outubro/98. Foram coletadas amostras de solo em toda a área alagadiça, de água subterrânea em pontos selecionados (MPz-01 a MPz-05) e águas superficiais (AS-I a AS-VI) que cortam a área.

Os parâmetros químicos analisados foram: sódio, potássio, cálcio, magnésio, manganês, ferro, aluminio, cloreto, sulfato e alcalinidade (Apêndice III).

A coleta da água subterrânea na área alagadiça foi realizada através da cravação de minipiezômetros.

\section{b1. SOLOS}

Foram coletadas 22 amostras de solo para determinação das concentrações de manganês na área alagadiça. Em alguns pontos, a coleta foi realizada em profundidades distintas (Figura 13). A Tabela 08 apresenta os resultados analíticos obtidos:

Tabela 08 - Resultados analíticos das amostras de solo $(\mathrm{mg} / \mathrm{Kg})$

\begin{tabular}{|c|c|c|c|}
\hline Sondagens & $\mathrm{Mn}$ & Sondagens & $\mathrm{Mn}$ \\
\hline SD-01 A & 5723,23 & $\begin{array}{l}\text { SD-10A } \\
\text { SD-10B }\end{array}$ & $\begin{array}{l}59,46 \\
52,27\end{array}$ \\
\hline SD.02 A & 110,00 & $\mathrm{SD}-11 \mathrm{~A}$ & 2378,36 \\
\hline SD-03 A & 260,00 & $\begin{array}{l}\text { SD-12 A } \\
\text { SD-12 B }\end{array}$ & $\begin{array}{l}1102,47 \\
1156,88\end{array}$ \\
\hline SD. $04 \mathrm{~A}$ & 1692,08 & $\begin{array}{l}S D-13 A \\
S D-13 B\end{array}$ & $\begin{array}{l}4931,04 \\
3567,54\end{array}$ \\
\hline SD-05 A & 1050,00 & SD-14 A & 3171,14 \\
\hline SD-06 A & 55,90 & $S D-15 A$ & 775,44 \\
\hline SD-07 A & 41027,68 & $\begin{array}{l}\text { SD-16 A } \\
\text { SD-16 B }\end{array}$ & $\begin{array}{c}3493,21 \\
532,65\end{array}$ \\
\hline $\begin{array}{l}S D-08 \mathrm{~A} \\
S D-08 \mathrm{~B}\end{array}$ & $\begin{array}{c}35589,32 \\
963,73\end{array}$ & & \\
\hline $\begin{array}{l}\text { SD-09 A } \\
\text { SD-09 B }\end{array}$ & $\begin{array}{c}4087,8 \\
2514,62\end{array}$ & & \\
\hline
\end{tabular}

\begin{tabular}{|c|c|}
\hline Sondagens & Mn \\
\hline SD-17 A & 5078,78 \\
SD-17 B & 554,95 \\
\hline SD-18 A & 693,69 \\
\hline SD-19 A & 5586,66 \\
\hline SD-20 A & 16112,13 \\
SD-20 B & 1172,02 \\
SD-20 C & 507,62 \\
\hline SD-21 A & 328,46 \\
SD-21 B & 343,39 \\
SD-21 C & 261,28 \\
\hline SD-22 A & 2052,9 \\
\hline
\end{tabular}




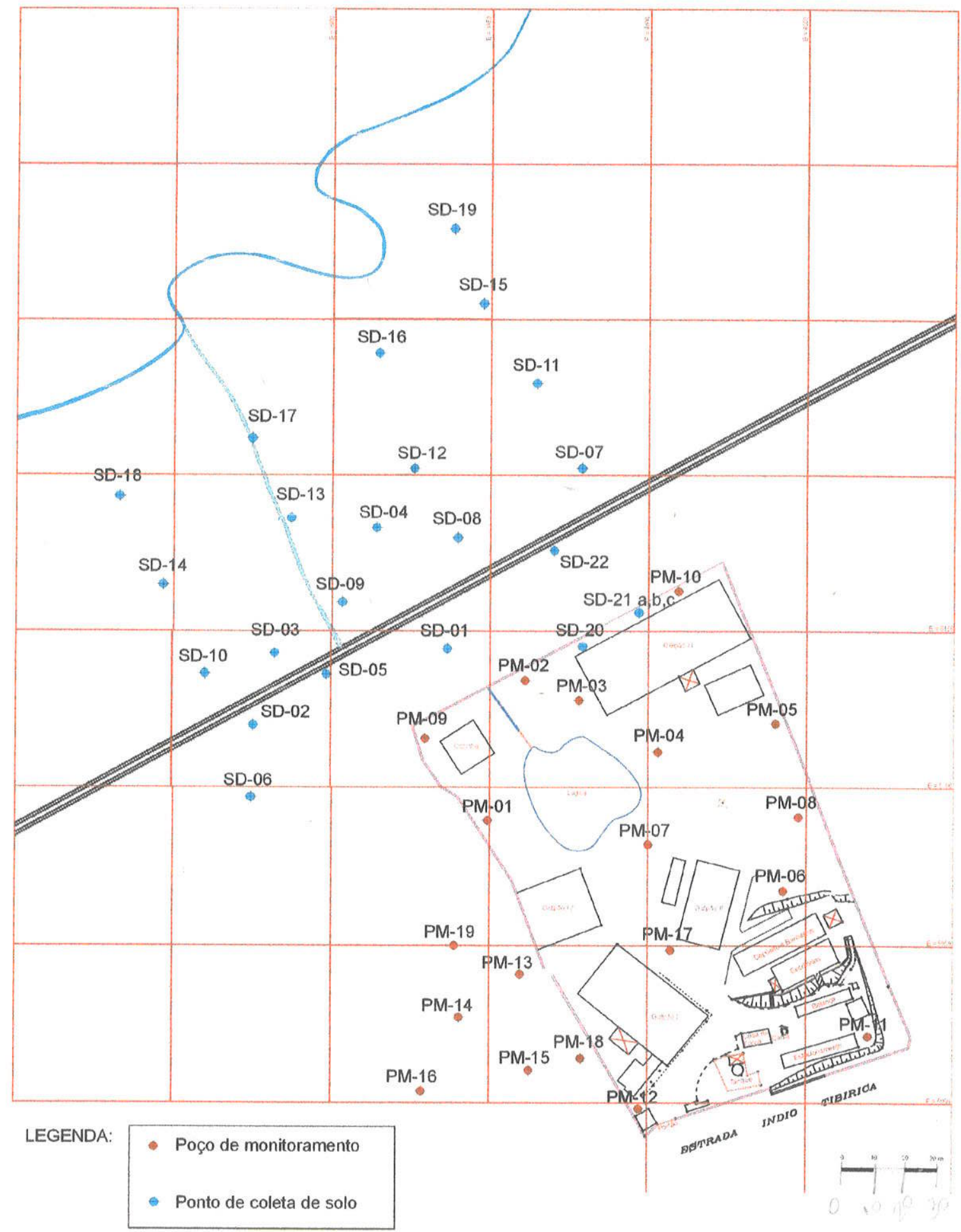

Figura 13 - Localização dos pontos de amostragem de solo 
A partir dos resultados ilustrados na Tabela 08 , notam-se que todos os pontos onde foram efetuadas as coletas de solo apresentaram elevadas concentrações de manganês, variando de 52,27 (SD-10B) a 41.027, 68 mg/Kg (SD-07A).

As profundidades mais rasas de coleta $(0,25 \mathrm{~m})$ apresentaram as maiores concentrações de manganês em solo, ocorrendo um decréscimo destas concentrações em profundidade. Contudo, não existe uma norma regulamentadora para comparar as concentrações deste metal em solo.

Esses altos valores identificados na área alagadiça mostram que a contaminação originada à montante atingiu toda a área. Neste local, atua o processo de evaporação, o que faz com que os sais dissolvidos se precipitem, aumentando a concentração em solo. Fonte adicional de contaminação que contribui para o acúmulo de manganês são os sedimentos na forma de pó, que atingem a área através do processo eólico e águas superficiais, carreadas com as águas da chuva, além da própria água subterrânea que é o vetor principal de contaminação. 


\section{b2. ÁGUAS SUBTERRÂNEA E SUPERFICIAL}

As concentrações máximas de manganês e sulfato obtidas nas análises químicas foram encontradas nos arredores dos depósitos residuais. O PM-19 apresentou concentrações de manganês e sulfato de 4876 mg/L e 10105 mg/L. Estas altas concentrações foram encontradas também no evento de monitoramento realizado em outubro de $1998 \mathrm{com}$ valores de $6800 \mathrm{mg} / \mathrm{L}$ e $14820 \mathrm{mg} / \mathrm{L}$, respectivamente.

As diferenças nas concentrações desses dois parametros entre as duas etapas de campo estão relacionadas a fenômenos de diluição ocasionados pela recarga durante o período de novembro/98 à abril/99.

Os valores de $\mathrm{Eh}$ e $\mathrm{pH}$, plotados no diagrama de equilíbrio Eh-pH (sistema Mn$\mathrm{O}-\mathrm{H}$ ), mostraram que os pontos amostrados, assim como na primeira campanha de amostragem, estão contidos no campo de estabilidade ocupado pelo $\mathrm{Mn}^{2+}$. Isto indicou que o manganês encontra-se dissolvido na água subterrânea (Figura 14).

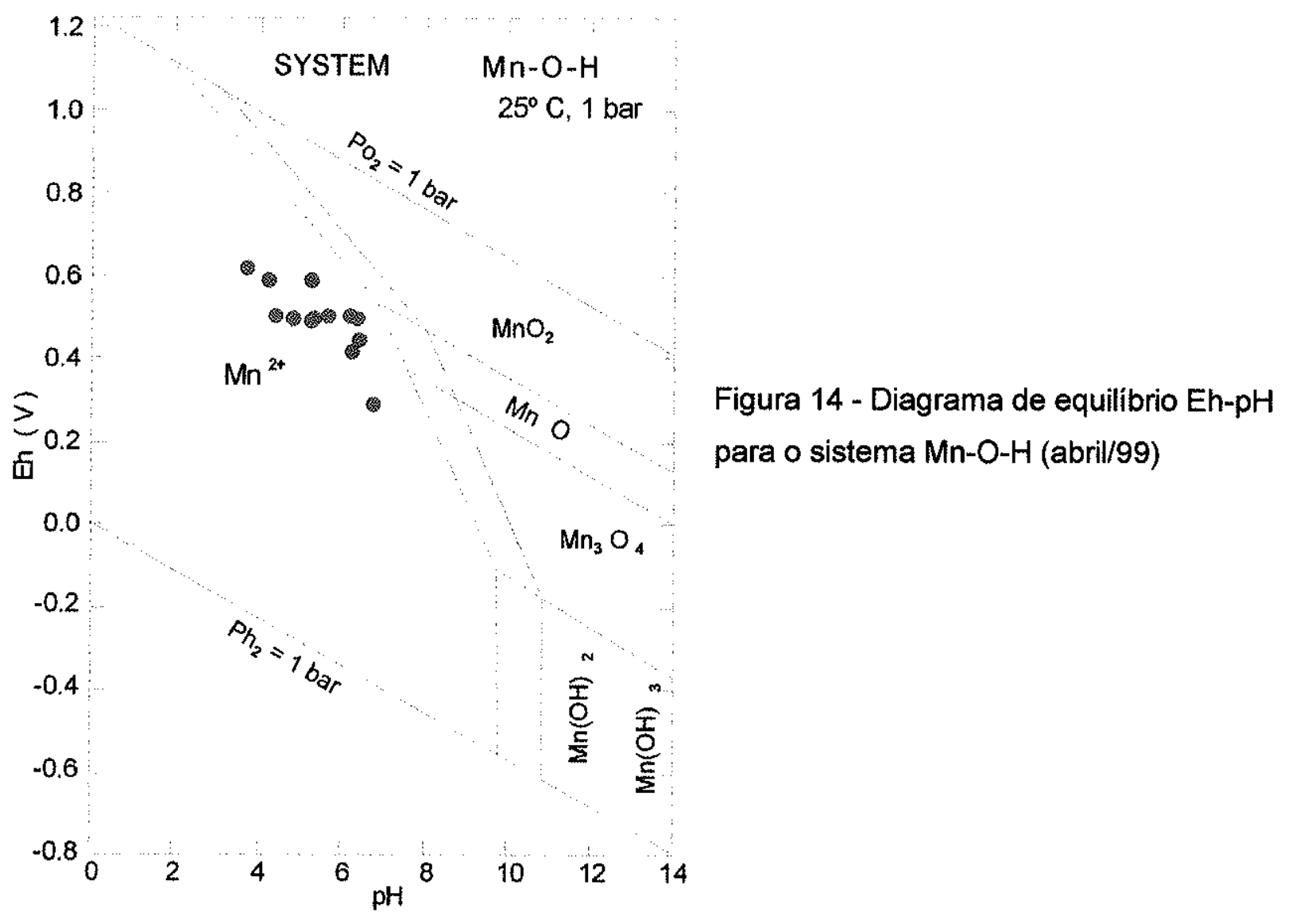


Os PMs 09 e 10, próximos ao limite noroeste da indústria, apresentaram concentrações de manganês de 354 mg/L e 112 mg/L, respectivamente. Estes valores foram mais baixos que as concentrações de 1998. O poço PM-10 apresentou concentrações mais baixas porque está locado na margem leste da pluma de contaminação e não é afetada pela entrada de contaminantes da área deste depósito.

Os PMs 02, 04, 05, 16, 17 e 18 não foram amostrados, uma vez que apresentavam-se danificados e não puderam ser recuperados para os trabalhos.

As amostras coletadas na área alagadiça, através de minipiezômetros (MPz), apresentaram concentrações elevadas de manganês, atingindo 2725 mg/L no MPz-02 próximo ao limite da indústria. Amostragem do MPz-03, situado a $75 \mathrm{~m}$ a sudoeste do limite da área, apresentou somente $20 \mathrm{mg} / \mathrm{L}$ de manganês. Este ponto está localizado na margem oeste da pluma de contaminação.

Amostras da água subterrânea do lado oposto da estrada de ferro apresentaram concentrações significativas de manganês (388 mg/L no MPz-04) e sulfato (792 mg/L na MPz-05). Isto deve estar relacionado a dois possíveis mecanismos:

1. Durante o período de chuvas, a área alagadiça entre a área de estudos e a estrada de ferro (Foto 06) está completamente inundada e há fluxo de água superficial através da tubulação (Foto 07) que corta esta estrada. Neste caso, a área alagadiça atrás da estrada de ferro recebe carga de contaminantes da água superficial e alaga uma área muito maior se comparada com os períodos de seca (maio a outubro). Existe ainda a descarga da água subterrânea das

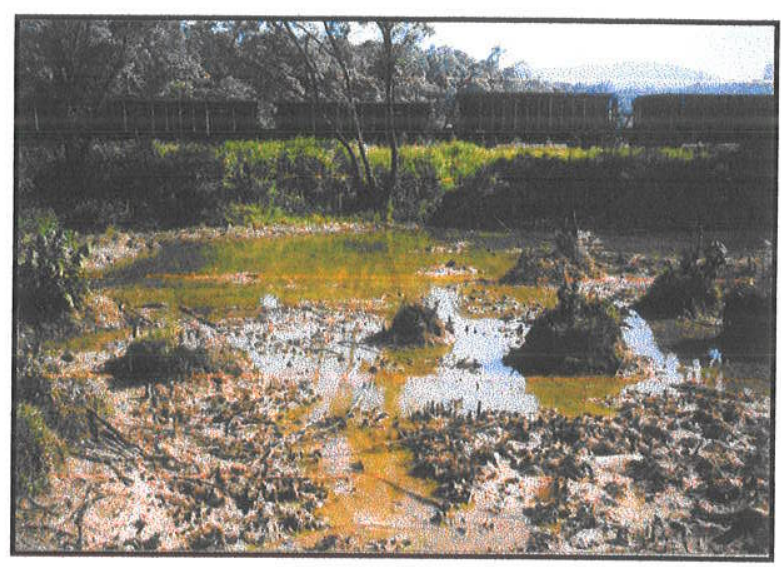

Foto 06 - Área alagadiça entre a área e a estrada de ferro

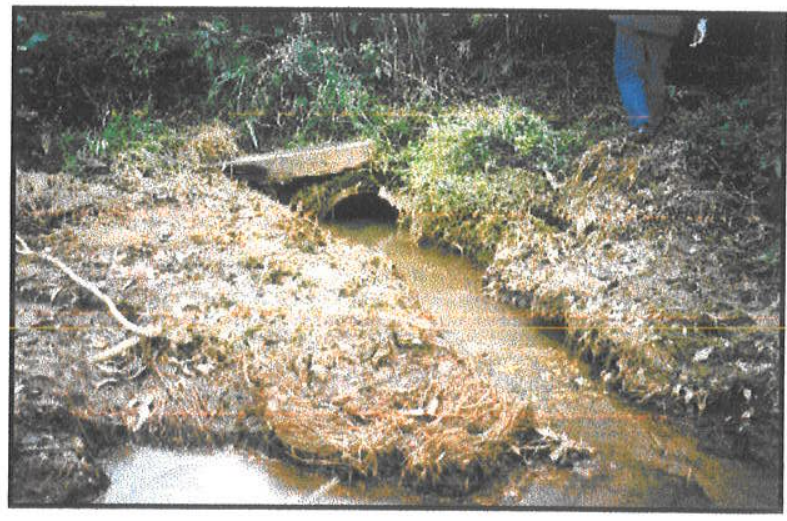

Foto 07 - Tubulação que corta a estrada de ferro 
áreas à montante em direção à área alagadiça e que também contribui com a contaminação do solo e das águas subterrâneas localizadas do outro lado da estrada de ferro (em direção ao Córrego Taiaçupeba Mirim). É possível avaliar a importância do mecanismo (1) pelo monitoramento da área durante o período de chuvas.

2. Outra possibilidade está relacionada à chegada de contaminantes através de transporte eólico, a partir das áreas de manipulação da indústria. No entanto, este mecanismo não explica as altas concentrações de manganês na água subterrânea.

Finalmente, as amostras de água superficial (AS-II) são alta na passagem desta drenagem por debaixo da estrada de ferro $(164 \mathrm{mg} / \mathrm{L}$ de manganês e $5369 \mathrm{mg} / \mathrm{L}$ de sulfato). A drenagem principal, o Córrego Taiaçupeba Mirim, apresentou concentrações $<1 \mathrm{mg} / \mathrm{L}$ de manganês e $23 \mathrm{mg} / \mathrm{L}$ de sulfato.

A Tabela 09 apresenta os resultados desses dois parâmetros para os PMs, MPzs e AS:

Tabela 09 - Resumo das concentrações de manganês e sulfato (mg/L)

\begin{tabular}{|c|c|c|c|c|c|}
\hline Pogos & Manganés & Sulfato & Pogos. & Manganés & Sulfato \\
\hline PM-01 & 2,63 & 19 & MPz-01 & 1144 & 13056 \\
\hline PM-03 & 1475,20 & 5625 & $M P z=02$ & 2725 & 564 \\
\hline PM-06 & 22,62 & 1056 & MPz-03 & 20,3 & 135 \\
\hline PM-07 & 2127,00 & 7033 & $M P z-04$ & 388 & 664 \\
\hline PM-08 & 25,88 & 75 & $M P Z-05$ & 110,05 & 792 \\
\hline PMOO & 354,70 & 1593 & As-1 & 46,55 & 1327 \\
\hline PM-10 & 112,30 & 1536 & AS-II & 164,45 & 5369 \\
\hline PM-11 & 3,94 & 9 & AS III a & 0,59 & 14 \\
\hline PM-12 & 0,58 & 10 & $A S-\| 111 b$ & 0,65 & 23 \\
\hline $\mathrm{PM}-13$ & 799,20 & 2048 & As.V & 0,08 & 15. \\
\hline PM-14 & 435,20 & 1408 & AS-V & 0,73 & 19 \\
\hline PM-15 & 1401,50 & 400 & AS-VI & 0,64 & 20 \\
\hline PM-19 & 4876 & 10105 & & & \\
\hline
\end{tabular}


As Figuras 15 e 16 apresentam a localização dos pontos de amostragem dos minipiezômetros (MPz) e das águas superficiais (AS). Estas figuras apresentam ainda as plumas de contaminação para o manganês e sulfato. 


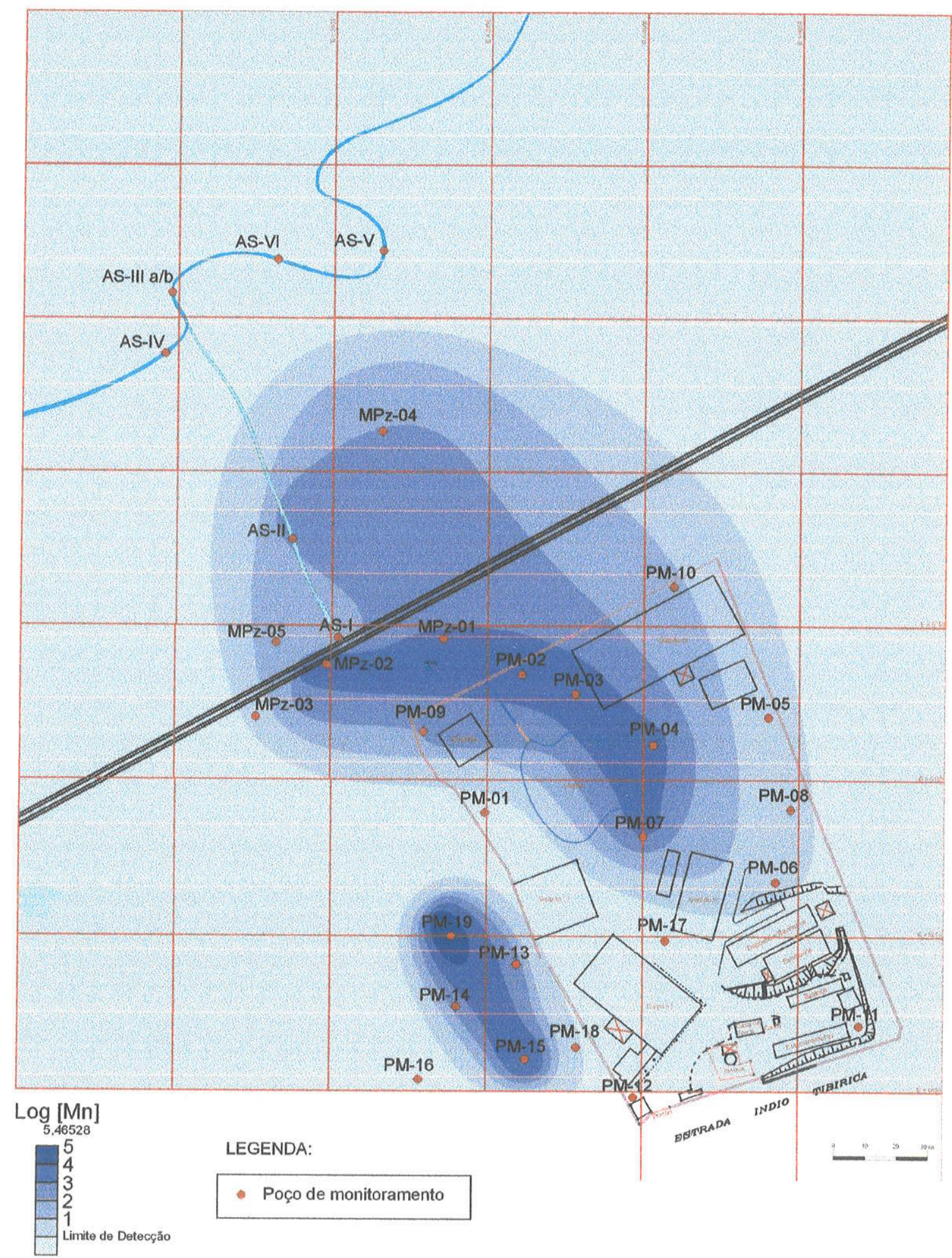

Figura 15 - Pluma de contaminação para manganês (abril/99) 


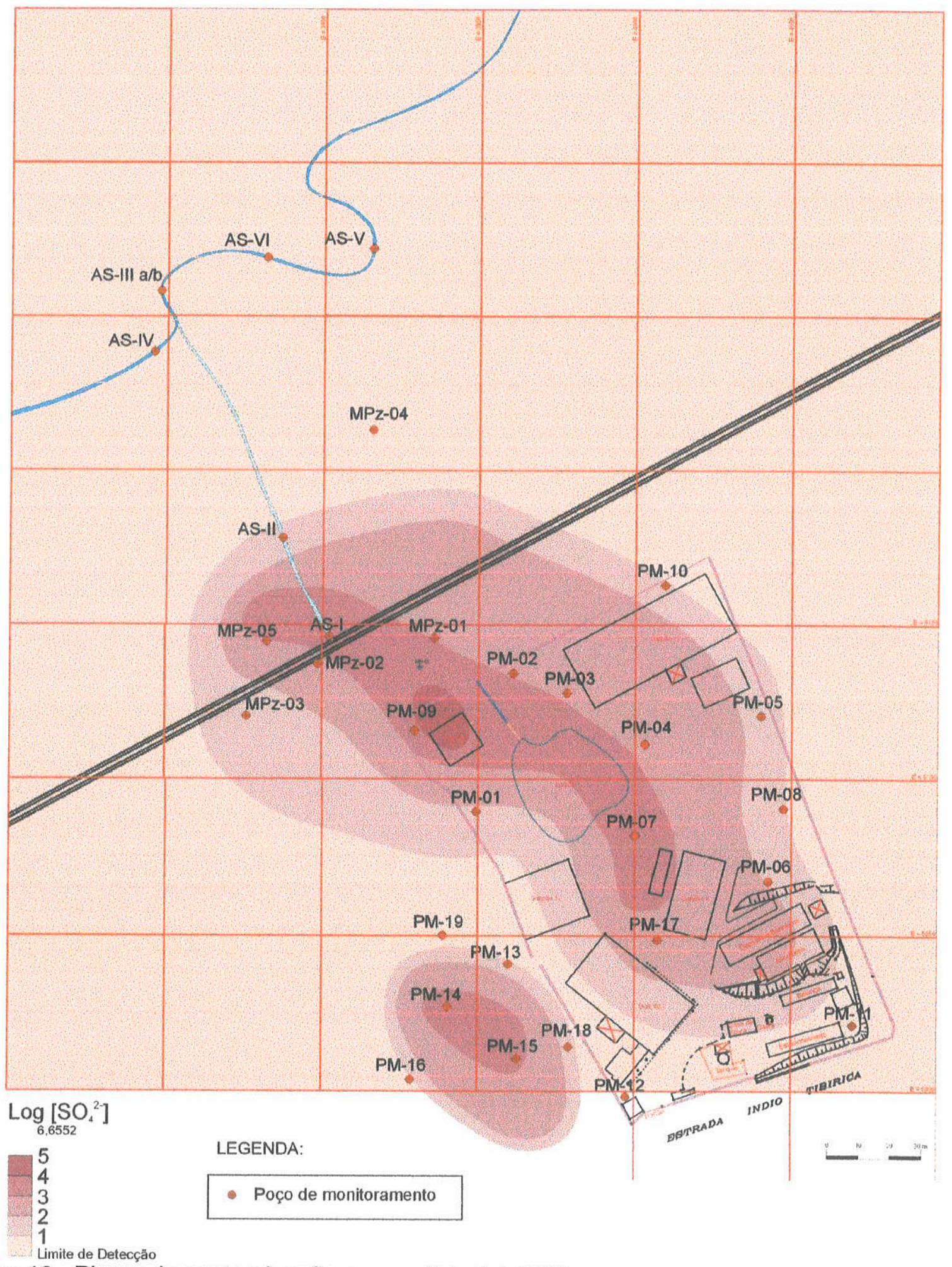

Figura 16 - Pluma de contaminação para sulfato (abril/99) 


\subsubsection{Modelagem Hidrogeoquímica}

A possibilidade de precipitação das espécies de manganês dissolvidas foi verificada através de modelagem hidrogeoquímica utilizando-se o modelo Wateq4f (Plummer et al., 1976). Os resultados apresentados na modelagem com valores maiores do que zero indicam precipitação do mineral e valores menores que zero, fases dissolvidas. É importante salientar que o fator tempo não foi incluído nos cálculos e estas reações podem demorar um tempo muito longo para acontecer.

Um aspecto importante é o comportamento do manganês, influenciado por complexação, especialmente com sulfato. Esta complexação é importante em amostras com alta concentração deste ânion. $O$ manganês presente em complexos não fica disponível para precipitação de minerais.

A modelagem hidrogeoquímica foi efetuada considerando as amostras dos "PMs, MPzs e AS" cujos resultados estão apresentados nas Tabelas 10 a 13

O Apêndice IV apresenta como modelo os dados de entrada no programa Wateq4f dos parâmetros do poço PM-01 referente ao segundo evento de monitoramento realizado em abril de 1999. 
Tabela 10 - Modelagem hidrogeoquímica da água subterrânea (outubro/98)

\begin{tabular}{|c|c|c|c|c|c|c|c|}
\hline $\begin{array}{c}\text { Poço de } \\
\text { monitoramento }\end{array}$ & $\underset{[\mathrm{atm}]}{\log \mathrm{PCO}_{2}}$ & Calcita & $\mathrm{Fe}(\mathrm{OH}) 3$ & Manganita & Pirolusita & Rodocrosita & Gipso \\
\hline PM-01 & $-2,93$ & $-1,49$ & 1,73 & 1,28 & 1,41 & $-0,23$ & $-0,89$ \\
\hline PM-02 & $-2,25$ & $-3,23$ & 0,65 & $-3,17$ & $-4,93$ & $-2,13$ & $-1,87$ \\
\hline PM-03 & $-3,13$ & $.5,68$ & 1,22 & $-4,54$ & $-7,18$ & $-3,49$ & $-0,15$ \\
\hline $\mathrm{PM}-04$ & $-2,41$ & 0,03 & 1,73 & 2,02 & 1,83 & 1,33 & $-0,17$ \\
\hline PM-05 & $-2,88$ & 0,11 & 1,82 & 2,81 & 2,83 & 1,45 & $-1,40$ \\
\hline PM-06 & $-3,07$ & $-0,91$ & 1,79 & 2,20 & 2,65 & 0,22 & $-1,33$ \\
\hline PM-07 & $-3,30$ & $-0,80$ & 1,78 & 3,87 & 4,43 & 1,54 & 0,0 \\
\hline PM-08 & $-2,99$ & $-2,38$ & 1,49 & 0,46 & 0,34 & $-0,87$ & $-1,60$ \\
\hline PM-09 & $-2,97$ & $-1,38$ & 2,16 & 2,64 & 2,91 & 0,94 & $-0,12$ \\
\hline$P M-10$ & $-2,52$ & $-0,72$ & 2,08 & 2,25 & 2,90 & 0,61 & $-0,45$ \\
\hline PM-11 & $-3,12$ & $-3,49$ & 1,58 & $-1,12$ & $-0,79$ & $-3,02$ & $-4,03$ \\
\hline$P M-12$ & $-2,89$ & $-2,36$ & 1,68 & 0,98 & 0,89 & $-0,27$ & $-3,70$ \\
\hline$P M-13$ & $-2,45$ & $-4,40$ & 1,87 & $-2,98$ & $-5,61$ & $-1,27$ & $-1,24$ \\
\hline PM-14 & $-2,56$ & $-1,76$ & 3,40 & $-1,26$ & $-4,47$ & 0,93 & $-1,41$ \\
\hline PM-15 & $-2,64$ & $-3,68$ & 0,87 & $-0,70$ & $-1,78$ & $-0,74$ & $-0,92$ \\
\hline PM-16 & $-1,40$ & $-7,92$ & $-4,39$ & $-13,1$ & $-18,95$ & $-7,05$ & $-2,03$ \\
\hline PM-17 & $-2,79$ & $-6,67$ & $-0,60$ & $-4,02$ & $-5,50$ & $-3,78$ & $-1,46$ \\
\hline$P M-18$ & $-2,45$ & $-6,51$ & $-0,30$ & $-4,71$ & $-6,05$ & $-4,28$ & $-0,83$ \\
\hline PM-19 & $-3,80$ & $-2,13$ & 1,96 & 3,29 & 3,46 & 0,84 & 0,10 \\
\hline
\end{tabular}

em negrito $=$ supersaturação 
Tabela 11 - Modelagem hidrogeoquímica da água subterrânea (abril/99)

\begin{tabular}{|c|c|c|c|c|c|c|c|c|}
\hline Amostra & $\begin{array}{l}P_{\mathrm{cO} 2} \\
(\mathrm{~atm})\end{array}$ & Calcita & $\mathrm{Fe}(\mathrm{OH})_{3}$ & Manganita & Pirolusita & Rodocrosita & Gipso & $\begin{array}{c}\mathrm{MnSO}_{4} \\
(\%)\end{array}$ \\
\hline PM-01 & -1.65 & -2.21 & 3.04 & -2.00 & -4.09 & -1.02 & -2.94 & 2.4 \\
\hline PM-03 & -1.39 & -4.53 & 0.75 & -4.87 & -8.82 & -1.85 & -0.28 & 42.0 \\
\hline PM-06 & -1.40 & -3.62 & 1.58 & -2.80 & -4.67 & -1.78 & -1.36 & 33.9 \\
\hline PM-07 & -1.45 & -2.14 & 0.90 & -0.39 & -1.89 & 0.27 & 0.15 & 44.1 \\
\hline PM-08 & -1.87 & -2.14 & 2.71 & -2.80 & -6.10 & -0.66 & -1.82 & 4.8 \\
\hline PM-09 & n.a. & n.a. & -0.19 & -5.59 & -8.06 & n.a. & -0.83 & 32.2 \\
\hline PM-10 & -0.95 & -1.95 & 1.60 & -2.89 & -5.64 & -0.55 & -0.27 & 31.1 \\
\hline PM-11 & -1.53 & -4.99 & 0.01 & -2.88 & -4.14 & -2.61 & -4.18 & 1.06 \\
\hline PM-12 & -1.85 & -2.63 & 0.44 & -2.21 & -3.50 & -2.22 & -3.04 & 1.03 \\
\hline PM-13 & -1.27 & -6.30 & -0.63 & -4.98 & -7.89 & -2.72 & -1.57 & 34.21 \\
\hline PM-14 & -2.24 & -1.65 & 3.98 & -2.02 & -6.94 & 1.11 & -1.05 & 29.79 \\
\hline PM-15 & -1.63 & -6.21 & -0.63 & -4.33 & -6.87 & -2.87 & -1.77 & 6.73 \\
\hline PM-19 & -2.25 & -2.19 & 2.95 & -1.24 & -4.76 & 0.64 & 0.01 & 42.9 \\
\hline
\end{tabular}

n.a. - não avałiado

em negrito - supersaturado

Tabela 12 - Modelagem hidrogeoquímica da água subterrânea da area alagadiça

\begin{tabular}{|c|c|c|c|c|c|c|c|c|}
\hline Amostra & $\begin{array}{c}\text { logPco2 } \\
\text { (atm) }\end{array}$ & Calcita & $\mathrm{Fe}(\mathrm{OH})_{3}$ & Manganita & Pirolusita & Rodocrosita & Gipso & $\begin{array}{c}\mathrm{MnSO}_{4} \\
(\%)\end{array}$ \\
\hline MPz-01 & $-2,22$ & $-3,66$ & 1,87 & $-4,98$ & $-11,07$ & $-1,12$ & $-4,59$ & $\mathbf{5 6 , 2}$ \\
\hline MPz-02 & n.a. & n.a. & 2,20 & $-4,87$ & $-11,25$ & n.a. & $-1,19$ & 3,4 \\
\hline MPz-03 & $-1,69$ & $-2,71$ & $-0,36$ & $-5,87$ & $-13,00$ & $-0,39$ & $-2,41$ & 12,1 \\
\hline MPz-04 & $-2,08$ & $-2,71$ & 1,80 & $-4,95$ & $-11,65$ & $-0,23$ & $-1,06$ & 15,9 \\
\hline MPz-05 & $-1,48$ & $-1,57$ & 0,92 & $-4,86$ & $-11,81$ & 0,82 & $-1,35$ & $\mathbf{2 4 , 3}$ \\
\hline
\end{tabular}

n.a. - não avaliado

em negrito - supersaturado 
Tabela 13 - Modelagem hidrogeoquímica da água superficial.

\begin{tabular}{|c|c|c|c|c|c|c|c|c|}
\hline Amostra & $\begin{array}{c}\text { logPco2 } \\
(\mathrm{atm})\end{array}$ & Calcita & $\mathrm{Fe}(\mathrm{OH})_{3}$ & Manganita & Piroluzita & Rodocrosita & Gipso & $\begin{array}{c}\mathrm{MnSO}_{4} \\
(\%)\end{array}$ \\
\hline AS-I & $-1,91$ & $-1,33$ & 1,35 & $-3,09$ & $-8,68$ & 0,61 & $-1,12$ & 32,0 \\
\hline AS-II & $-2,0$ & $-1,55$ & 2,61 & $-1,42$ & $-5,41$ & 0,75 & $-5,36$ & 49,1 \\
\hline AS-IIIa & $-2,57$ & $-2,86$ & 3,17 & $-1,96$ & $-4,70$ & $-1,75$ & $-3,53$ & 1,5 \\
\hline AS-IIlb & $-2,18$ & $-3,21$ & 2,86 & $-2,43$ & $-5,35$ & $-2,02$ & $-3,35$ & 2,3 \\
\hline AS-IV & $-2,10$ & $-2,26$ & 2,76 & $-4,15$ & $-7,76$ & $-2,95$ & $-3,55$ & 1,6 \\
\hline AS-V & $-2,09$ & $-3,33$ & 2,77 & $-3,34$ & $-7,00$ & $-2,10$ & $-3,42$ & 1,9 \\
\hline AS-VI & $-2,02$ & $-3,50$ & 2,65 & $-3,58$ & $-7,29$ & $-2,32$ & $-3,43$ & 1,9 \\
\hline
\end{tabular}

em negrito - supersaturado 


\section{DISCUSSÃO DOS RESULTADOS}

Os resultados analíticos obtidos nas duas campanhas de amostragem das águas subterrâneas indicaram elevadas concentrações de manganês em fase dissolvida.

Concentrações de sulfato também foram identificadas em concentrações acima dos limites de potabilidade apresentados pela Portaria 1469 do Ministério da Saúde.

A modelagem hidrogeoquimica, realizada com os dados obtidos em outubro de 1998, indicou várias amostras com $P_{\mathrm{cO} 2}$ maior que $10^{-3} \mathrm{~atm}\left(\mathrm{P}_{\mathrm{cO} 2}\right.$ atmosférica é $10^{-3,5}$ atm). Isto está provavelmente relacionado à decomposição de matéria orgânica conforme a equação 21 :

$$
\mathrm{CH}_{2} \mathrm{O}+\mathrm{O}_{2} \rightarrow \mathrm{CO}_{2}+\mathrm{H}_{2} \mathrm{O}
$$

Esta reação consome oxigênio dissolvido e cria um ambiente redutor com alta mobilidade de manganês. Muitas amostras estão supersaturadas com relação a minerais de $\mathrm{Mn}^{+4}$ como manganita e pirolusita. Entretanto, a concentração de $\mathrm{Mn}^{+4}$ nestes intervalos de $\mathrm{Eh}$ e $\mathrm{pH}$ é baixa e estes minerais não representam qualquer papel no controle da solubilidade do manganês.

A maioria das amostras está supersaturada em relação ao hidróxido de ferro, sugerindo a estabilidade da fase mineral sob as condições locais de $\mathrm{Eh}$ e $\mathrm{pH}$. Isto também é consistente com o decréscimo da mobilidade de metais na seqüência $\mathrm{Zn}$-Cu$\mathrm{Pb}$ relacionada à adsorção no $\mathrm{Fe}(\mathrm{OH})_{3}$, caracterizada por limites de adsorção distintos para espécies distintas (Sracek 1998).

Somente a amostra do PM-19 referente à campanha de amostragem realizada em outubro/98 apresentou supersaturação em relação ao gipso. Várias amostras, particularmente aquelas da parte menos elevada topograficamente (do PM-04 ao PM07, PM-09 e PM-10) apresentaram supersaturação em relação a rodocrosita $\left(\mathrm{MnCO}_{3}\right)$. Parece, entretanto, que a precipitação deste mineral não é de grande importância devido aos valores de $\mathrm{pH}$ e, portanto, as concentrações de carbonato são baixas. Isto 
significa que o principal mecanismo para a atenuação da contaminação por manganês é somente a dispersão.

O resultado da modelagem hidrogeoquímica das amostras das águas subterrânea coletadas em abril/99 e apresentadas na Tabela 12 mostra que a maioria das amostras estão supersaturadas em $\mathrm{Fe}(\mathrm{OH})_{3}$, sugerindo que esta fase está estável em baixas condições de Eh e pH. Por outro lado, a água não está saturada em relação aos minerais de $\mathrm{Mn}^{4+}$ and $\mathrm{Mn}^{3+}$, sugerindo instabilidade destas fases minerais. Poucas amostras estão supersaturadas em relação a rodocrosita. Isto é consistente com os altos valores de alcalinidade e de $\mathrm{P}_{\mathrm{CO} 2}$, geradas pela decomposição da matéria orgânica, como pode ser verificado na equação 21 .

Entretanto, valores de alcalinidade e valores relativamente baixos de $\mathrm{pH}$, indicam concentrações baixas de carbonato. Se houver precipitação de $\mathrm{MnCO}_{3}$, não haverá influência nas concentrações relativamente altas de $\mathrm{Mn}^{2+}$. Todas as amostras não estão saturadas com relação a calcita e a maioria das amostras não estão saturadas em relação ao gipso.

Há algumas amostras com complexos significativos de $\mathrm{Mn}^{2+}$ com sulfato, como pode ser verificado através da reação apresentada pela equação 22 :

$$
\mathrm{Mn}^{2+}+\mathrm{SO}_{4}{ }^{2-} \rightarrow \mathrm{MnSO}_{4}{ }^{0}
$$

Complexos de manganês com sulfato podem conter $40 \%$ do total de $\mathrm{Mn}^{2+}$ e assim, inviabilizar a precipitação de minerais de manganês.

Os resultados da modelagem hidrogeoquímica, para as amostras da água subterrânea da área alagadiça e apresentados na Tabela 10 , indicaram valores de $\mathrm{P}_{\mathrm{cO} 2}$ altos, dado consistente com a alta taxa de matéria orgânica na área alagadiça. A água não está supersaturada com relação a alguns minerais de manganês, exceto para a supersaturação da amostra Mpz-05 com relação a rodocrosita.

Os resultados da modelagem hidrogeoquímica da água superficial apresentados na Tabela 13 apresentam as amostras supersaturadas em relação ao $\mathrm{Fe}(\mathrm{OH})_{3}$, sugerindo transporte de ferro (e outros metais adsorvidos) por estas águas. Há 
também uma insaturação em relação a todos os minerais oxidados de manganês, como no caso das amostras de água subterrânea. Os valores de $\mathrm{P}_{\mathrm{CO} 2}$ estão decrescendo, mas não atingem o equilíbrio com a $\mathrm{P}_{\mathrm{cO} 2}$ atmosférica, que é $10^{-3.5}$ atm. A insaturação da água em relação a calcita e gipso sugere comportamento conservativo de cálcio e sulfato. 


\section{CONCLUSÕES}

A partir dos trabalhos realizados no local conclui-se:

Duas fontes de contaminação foram identificadas na área, a principal delas enterrada em terreno adjacente. Outra fonte são os particulados originados durante o manuseio de produtos estocados;

$>$ Testes de condutividade hdráulica indicaram valores máximo e mínimo de $4,28 \times 10^{-5} \mathrm{~cm} / \mathrm{s}$ e $2,14 \times 10^{-5} \mathrm{~cm} / \mathrm{s}$, respectivamente. As velocidades da água subterrânea calculadas variaram de $0,33 \mathrm{~cm} /$ dia a $17,26 \mathrm{~cm} / \mathrm{dia}$;

Foram identificadas concentrações extremamente elevadas de manganês e sulfato no PM-19 nos dois eventos de monitoramento realizados, em outubro/98 e abril/99. Estes resultados indicam a área a sudoeste da fábrica como fonte principal de contaminação, onde foram dispostos resíduos ricos em manganês;

$>$ A infiltração de água através deste depósito, pelo processo de lixiviação, adquire altas concentrações de manganes e sulfato dissolvidos. O fluxo da água subterrânea da fonte de contaminação até a área alagadiça (entre a indústria e a estrada de ferro) é relativamente curto e esta área já está completamente contaminada;

$>$ A área alagadiça à jusante (após a estrada de ferro) apresentou concentrações elevadas de manganês tanto em solo quanto em água subterrânea;

A modelagem hidrogeoquímica da água subterrânea com os dados de outubro/98 mostra que as amostras estão supersaturadas em relação aos minerais de $\mathrm{Mn}^{4+}$, manganita e pirolusita. Por outro lado, a complexação com sulfato representa importante papel, pois até $40 \%$ do manganês total está presente sob a forma do complexo $\mathrm{MnSO}_{4}{ }^{\circ}(\mathrm{aq})$. Várias amostras de água subterrânea da porção norte da área investigada (à jusante da antiga lagoa) estão supersaturadas em relação a rodocrosita, $\mathrm{MnCO}_{3}(\mathrm{~s})$. Isto representa uma provável conseqüência da decomposição de matéria orgânica com a resultante produção de alcalinidade;

De acordo com as análises químicas a maioria das amostras se encontram acima do limite de potabilidade estabelecido pela Portaria 1.469;

O resultado da modelagem hidrogeoquímica das amostras de água subterrânea 
coletadas em abril/99 apresentam em sua maioria amostras supersaturadas em hidróxido de ferro $\left(\mathrm{Fe}(\mathrm{OH})_{3}\right)$, sugerindo que a fase está estável nas condições do aqüífero. A água não está saturada em relação aos minerais de $\mathrm{Mn}^{4+}$ e $\mathrm{Mn}^{3+}$, sugerindo instabilidade destas fases minerais. Poucas amostras estão supersaturadas com relação a rodocrosita. Isto é consistente com relação aos altos valores de alcalinidade e de $\mathrm{P}_{\mathrm{CO} 2}$, gerados por decomposição de matéria orgânica;

A modelagem hidrogeoquímica referente às amostras da área alagadiça indicou que a água não está supersaturada com relação a alguns minerais de manganês, exceto para a supersaturação da amostra MPz-05 em relação a rodocrosita;

A modelagem hidrogeoquímica da água superficial apresentou amostras supersaturadas em relação ao $\mathrm{Fe}(\mathrm{OH})_{3}$, sugerindo transporte de ferro (e outros metais adsorvidos) por estas águas. Há também uma insaturação com relação a todos os minerais oxidados de manganês;

A complexação de manganês com sulfato é importante em amostras com alta concentração de sulfato. $O$ manganês presente em complexos não fica disponível para precipitação de minerais. 


\section{RECOMENDAÇÕES}

Eliminação da principal fonte de contaminação da área através da retirada dos resíduos enterrados;

Recomenda-se 0 monitoramento em dois períodos, em altas e baixas pluviosidade, das águas subterrâneas e das águas superficiais, inclusive do córrego que corta a área, para verificação das concentrações e taxa de diluição, com análise química dos principais cátions e ânions de interesse e medidas in situ dos parâmetros físicoquímicos;

Instalação de minipiezômetros na área alagadiça na porção leste para verificação das concentrações em água subterrânea e modelagem hidrogeoquímica para comparação dos resultados,

Recomenda-se a mudança na prática de manuseio de produtos para evitar que contaminantes possam ser transportados por transporte eólico e/ou pelas águas superficiais. 


\section{REFERÊNCIAS BIBLIOGRÁFICAS}

ABNT - ASSOCIAÇÃO BRASILEIRA DE NORMAS TÉCNICAS (1997) Construção de Poços de Monitoramento e Amostragem - NBR 13895. Rio de Janeiro, $21 \mathrm{p}$.

ALMODOVAR, M.L.N (2000) A Origem Natural da Poluição por Cromo no Aqüifero Adamantina, Municipio de Urânia (SP. Tese de Doutoramento. Instituto de Geociências da Universidade de São Paulo.

AMARANTE, A. (1997) Comportamento geoquímico de Metais Pesados em Sedimentos Argilosos da Bacia de São Paulo, Suzano - SP. Dissertação de Mestrado. Instituto de Geociências da Universidade de São Paulo. 98 p.

APPELO, C.A.J. \& POSTMA, D. (1993) Geochemistry, Groundwater and Pollution. A:A. Balkema Rotterdam/ Brookfield, $536 \mathrm{p}$.

BALL, J.W. E NORDSTROM, D.K. (1991) User's Manual for Wateq4f, with revised Thrmodynamic Data Base and Test Cases for Calculating Speciation of Major, Trace, and Redox Elements in Natural Waters. U.S. Geological Survey. Menlo Park, California. $59 \mathrm{p}$.

BROOKINS, D. G. (1988) Eh-pH Diagrams for Geochemisty. Springer-Verlag Berlin Heidelberg New York London Paris Tokyo, $176 \mathrm{p}$.

CETESB - COMPANHIA DE TECNOLOGIA DE SANEAMENTO AMBIENTAL DO ESTADO DE SÃO PAULO (2001) Estabelecimento de Valores Orientadores para Solos e Água Subterrânea no Estado de São Paulo. Relatório Final. São Paulo, $246 \mathrm{p}$.

COMPANHIA DE PESQUISA DE RECURSOS MINERAIS - CPRM (1990) Projeto Santa Isabel/Mogi das Cruzes/Mauá - Relatório Final. São Paulo, CPRM, v.1.

DEUTSCH, W.J. (1997) Groundwater Geochemistry - Fundamentals and Appications to Contamination. Lewis Publishers - Boca Taton/New york, $221 \mathrm{p}$.

DREVER, J.I., (1997) The Geochemistry of Natural Waters: Surface and Groundwater Environments. $3^{\text {rd }}$ Ed., Prentice Hall, New Jersey, 436 p.

FENZL, N. (1988) Introdução à Hidrogeoquímica. Universidade Federal do Pará, Belém, $189 \mathrm{p}$. 
FETTER, C.W. (1988) Applied hydrogeology. Merril Publishing Company, Columbus, Ohio. $592 \mathrm{p}$.

FREEZY, R.A. \& CHERRY, J.A. (1979) Groundwater. New Jersey, Prentice Hall. Inc. $604 \mathrm{p}$.

HYPOLITO, R. (1980) Criptomelana - Sintese e Estabilidade. Tese de Livre Docência. Isntituto de Geociências da Universidade de São Paulo. 160 p.

KELLY, W.R. (1996) Heterogeneites in Groundwater Geochemistry in a Sand Aquifer Beneath an Irrigated Field. Journal of Hydrology, v. 198, p. 154-176.

LEE, D.R. \&CHERRY, J.A. (1978) A Field Exercise on Groundwater Flow Using Seepage Meters and Mini-Piezometers. Journal of Geological Education, v. 27, p. 06-10.

MELLO JUNIOR, R.F. de (1998) Geoquímica da Contaminação Industrial do Solo e do Subsolo por Metais Pesados na Região de Suzano - SP. Dissertação de Mestrado. Instituto de Geociências da Universidade de São Paulo. 113 p.

MINISTÉRIO DA SAÚDE (2001) Portaria 1469. Brasil, 17 p.

NICHOLSON, R.V., CHERRY, J.A. \& REARDON, E.J. (1983) Migration of Contaminants in Groundwater at a Landfill: A Case Study. Journal of Hydrology, v. 63, p. 131176.

NIMER, E. (1977) Geografia do Brasil - Região Sudeste. IBGE Rio de Janeiro. V 3 , p51-89.

OLIVEIRA, E. (1992) Contaminação de aqüiferos por Hidrocarbonetos provenientes de Vazamentos de Tanques de Armazenamento Subterrâneo. Dissertação de Mestrado - Instituto de Geociências da Universidade de São Paulo.

PLUMMER L.N., JONES B.F., TRUESDALL A. H. (1976) Wateq4f - A Fortran IV version of Wateq, a computer program for calculating chemical equilibria of natural waters. U.S. Geological Survey Water Resources Investigations, report 76-13.

PREFEITURA MUNICIPAL DE SUZANO (1991) Plano Diretor do Município. Município de Suzano. Dados Gerais. p. 33-38

SIGOLO, J.B. (1998) Aplicação da Geoquímica de Superfície na análise da Mobilidade e Concentração de Metais Pesados em Ambiente Tropical. Tese de Livre 
Docência. Instituto de Geociências da Universidade de São Paulo. 216 p.

SRACEK A. (1998) Environmental Geochemistry, Notas de curso, Universidade de São Paulo.

STUMM W. AND MORGAN J.J. (1981) Aquatic Chemistry. John Wiley \& Sons, 780 p.

SZIKSZAY, M. (1981) Hidrogeoquímica das Fontes de águas da Prata, Estado de São Paulo - Origem, Classificação e Caracterização. Tese de Livre Docência. Instituto de Geociências da Universidade de São Paulo. 193 p.

VARSÁNYI, I AND KOVÁCS, L.Ó. (1996) Chemical evolution of groundwater in the River Danube deposits in the southern part of the Pannonian Basin (Hungary). Applied Geochemistry, Vol. 12, pp 625-636. 


\section{APÊNDICE I}

Perfis Construtivos dos Poços de Monitoramento 


\begin{tabular}{|c|c|c|c|c|c|c|c|}
\hline \multicolumn{8}{|c|}{ DISSERTAÇÃO DE MESTRADO - VINICIUS ISHIMINE } \\
\hline \multicolumn{8}{|c|}{ SUZANO - SÃO PAULO } \\
\hline \multicolumn{3}{|c|}{ EQUIPAMENTO: TRADO MANUAL } & \multicolumn{3}{|c|}{ PERFURAÇÃO: 4" } & \multicolumn{2}{|c|}{ REVESTIMENTO: $2 "$} \\
\hline \multicolumn{2}{|c|}{ PM-01 } & \multicolumn{3}{|c|}{ PM-02 } & \multicolumn{3}{|c|}{ PM-03 } \\
\hline Inicio: 08/1998 & Término: 08/1998 & Inicio: $08 / 1$ & & Término: 08/1998 & Inici & $08 / 1998$ & Término: 08/1998 \\
\hline Profundidade: $2,30 \mathrm{~m}$ & N.A. Estab: $1,20 \mathrm{~m}$ & Profundidade & $1,30 \mathrm{~m}$ & N.A. Estab.: $0,70 \mathrm{~m}$ & Prof & didade: $4,37 \mathrm{~m}$ & N.A. Estab.: $0,70 \mathrm{~m}$ \\
\hline
\end{tabular}
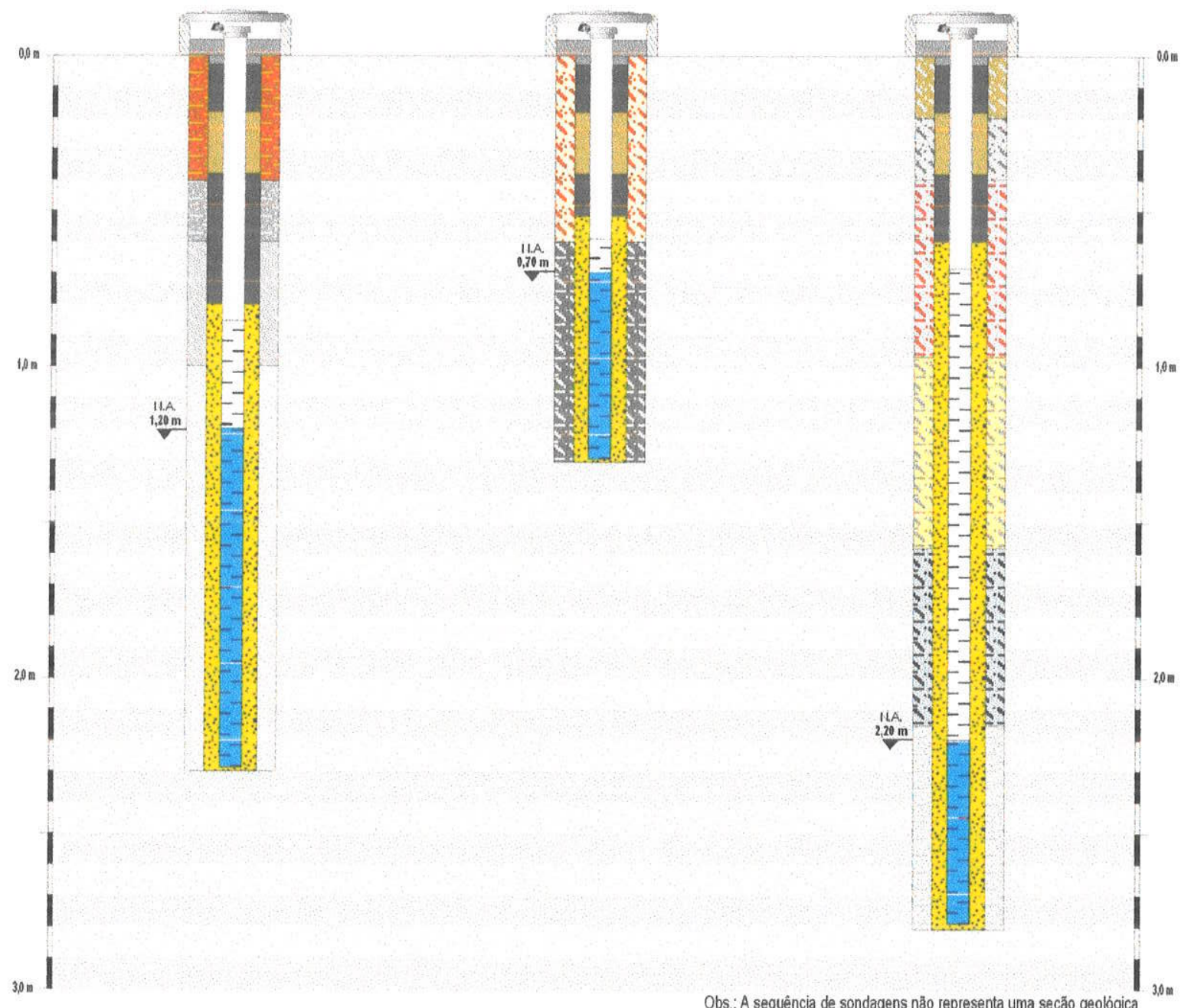

Obs.: A sequência de sondagens não representa uma seção geológica

Legenda (Construtivo)

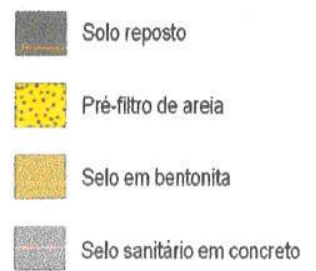

Legenda (Litologia)

5. Solo argilo-siltoso, pouco arenoso, pouco micáceo, vermelho com porçōes brancas (caulinicas) 5.:- Solo argilo-siltoso, pouco arenoso, pouco micáceo, cinza-escuro, plástico

Solo argiloso, pouco arenoso, com pedregulhos, vermetho e amarelo

5. Solo argilo-siltoso, pouco arenoso, pouco micáceo, cinza amarelado

Solo argilo-siltoso, pouco arenoso, cinza escuro à preto, com raizes

Sil. Solo sitto-arenoso, com pedregulhos, vermelho amarelado
$1,0 \mathrm{n}$

2010

3004 


\begin{tabular}{|c|l|l|l|l|l|l|}
\hline \multicolumn{2}{|c|}{ EQUIPAMENTO: TRADO MANUAL } & \multicolumn{2}{c|}{ PERFURAÇÃO: 4" } & REVESTIMENTO: 2" \\
\hline \multicolumn{2}{|c|}{ PM-04 } & \multicolumn{3}{c|}{ PM-05 } & \multicolumn{2}{c|}{ PM-06 } \\
\hline Inicio: 08/1998 & Término: 08/1998 & Início: 08/1998 & Término: 08/1998 & Inicio: 08/1998 & Término: 08/1998 \\
\hline Profundidade: $2,10 \mathrm{~m}$ & N.A. Estab: $1,00 \mathrm{~m}$ & Profundidade: $2,30 \mathrm{~m}$ & N.A. Estab.: $1,50 \mathrm{~m}$ & Profundidade: $1,90 \mathrm{~m}$ & N.A. Estab.: 1,40 m \\
\hline
\end{tabular}
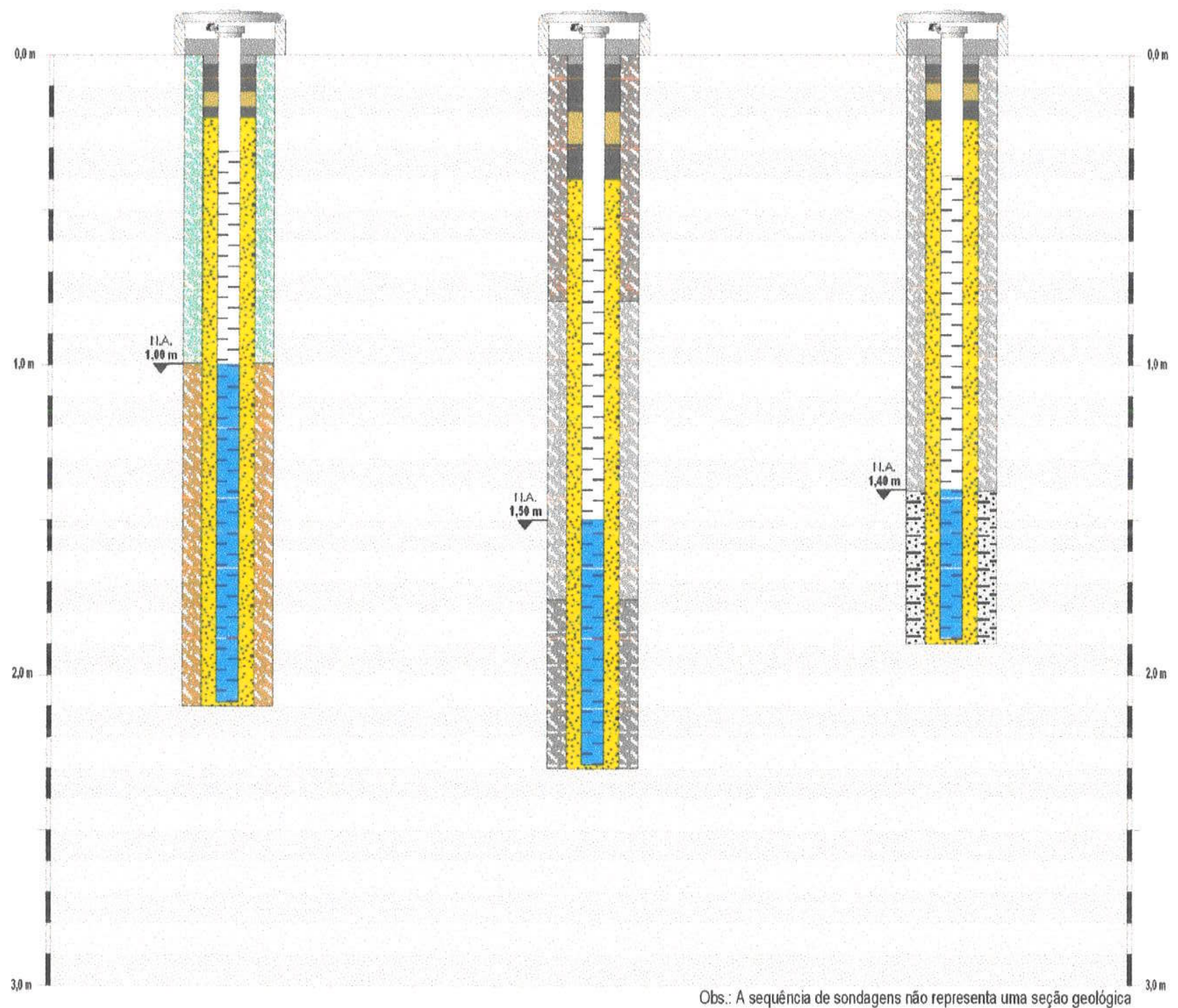

Legenda (Litologia)

Solo argilo-siltoso, pouco arenoso, com pedregulhos, cinza escuro, com manchas verdes

Solo silto-arenoso, pouco argiloso, com entulho, marrom

Solo argilo-arenoso, com pedregulhos, marrom claro

Solo argilo-siltoso, cinza-escuro

: $: \div$ Solo argilo-arenoso, cinza claro

Solo silto-argiloso, preto 


\begin{tabular}{|l|l|l|l|l|l|l|}
\hline \multicolumn{2}{|c|}{ EQUIPAMENTO: TRADO MANUAL } & \multicolumn{2}{c|}{ PERFURAÇÃO: 4" } & \multicolumn{2}{c|}{ REVESTIMENTO: 2" } \\
\hline \multicolumn{2}{|c|}{ PM-07 } & \multicolumn{3}{c|}{ PM-08 } & \multicolumn{2}{c|}{ PM-09 } \\
\hline Inicio: 08/1998 & Término: 08/1998 & Inicio: 08/1998 & Término: 08/1998 & Inicio: 08/1998 & Término: 08/1998 \\
\hline Profundidade: $3,00 \mathrm{~m}$ & N.A. Estab: $2,50 \mathrm{~m}$ & Profundidade: $2,90 \mathrm{~m}$ & N.A. Estab.: $2,10 \mathrm{~m}$ & Profundidade: $2,80 \mathrm{~m}$ & N.A. Estab.: $0,40 \mathrm{~m}$ \\
\hline
\end{tabular}

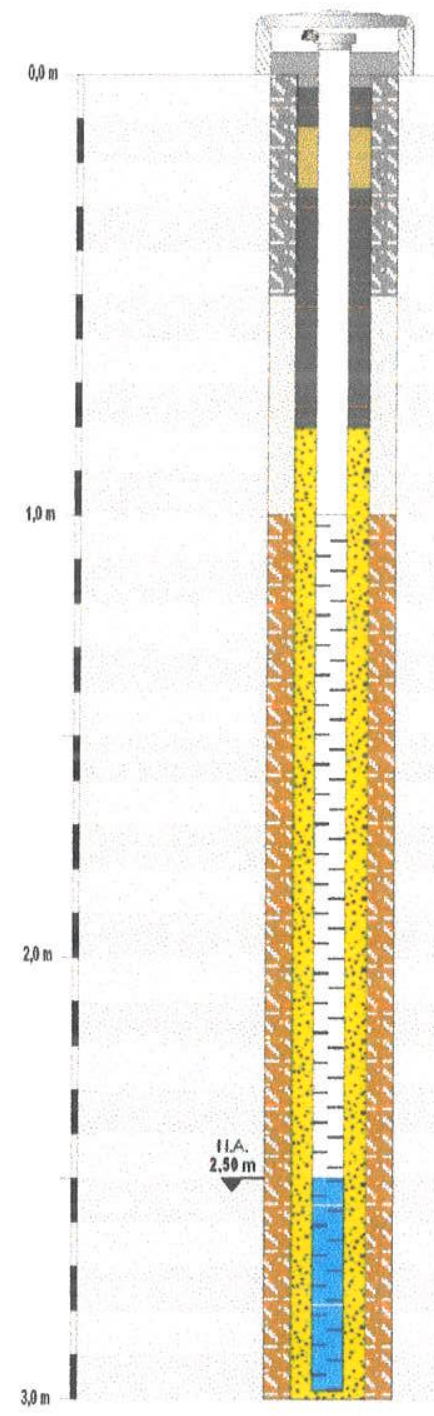

Legenda (Litologia)

Solo silto-argiloso, pouco arenoso, com grande quantidade de material branco pouco denso e empedrado

Solo argilo-arenoso, pouco micáceo, com grẵos milimétricos de quartzo cinza claro à branco

Solo argilo-arenoso, pouco micáceo, com grăos milimétricos de quartzo, cinza escuro

-7. Solo argilo-siltoso, com lâminas de material grafitoso, poco arenoso, marrom

- Solo arenoso (areia média), pouco argiloso, micáceo, cinza-escuro

Solo argiloso, pouco arenoso, cinza-escuro, com matéria orgánica

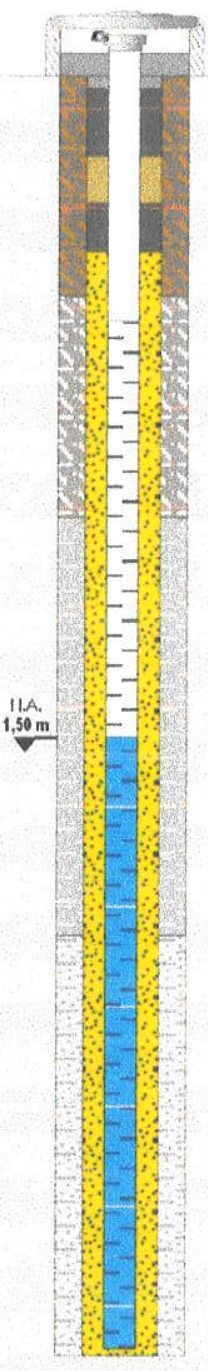

Obs:: A sequência de sondagens nåo representa uma seçăo geológica

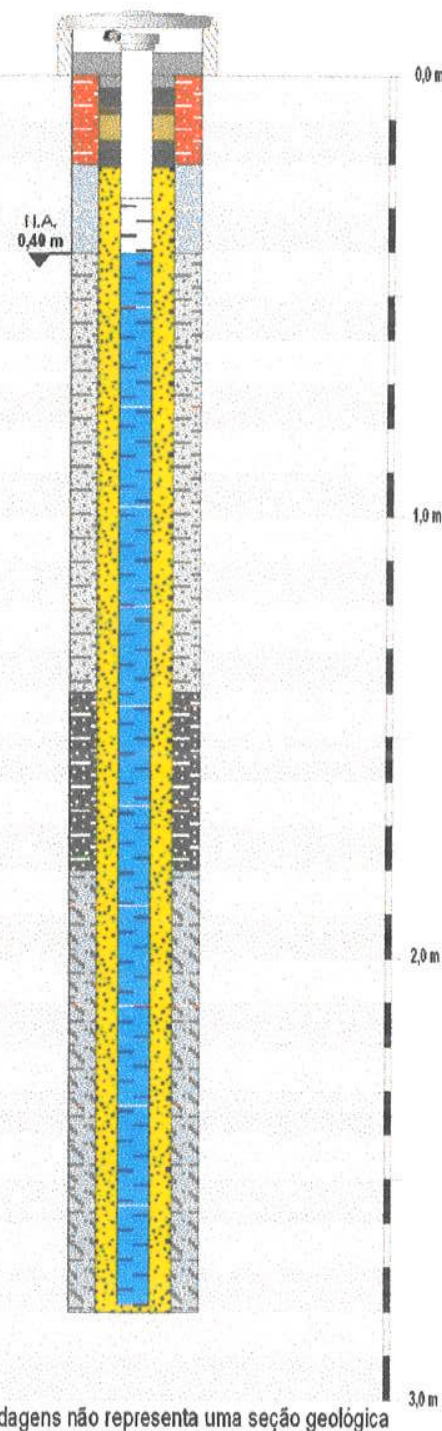

Solo argilo-siltoso, pouco arenoso, micáceo, cinza-escuro

Solo silto-argiloso, pouco arenoso, com entulho, preto

Solo argilo-arenoso, com entulho, vermelho

Solo arenoso (areia média e grossa), cinza

Solo argilo-siltoso, marrom escuro

Solo argilo-siltoso, marrom
$0,0 \mathrm{~m}$

$1,0 \mathrm{~m}$ 


\begin{tabular}{|c|c|c|c|c|c|c|}
\hline \multicolumn{2}{|c|}{ EQUIPAMENTO: TRADO MANUAL } & \multicolumn{2}{c|}{ PERFURAÇÃO: 4" } & \multicolumn{2}{c|}{ REVESTIMENTO: 2" } \\
\hline PM-10 & \multicolumn{3}{|c|}{ PM-11 } & \multicolumn{2}{c|}{ PM-12 } \\
\hline Inicio: 08/1998 & Término: 08/1998 & Início: 08/1998 & Término: 08/1998 & Início: 08/1998 & Término: 08/1998 \\
\hline Profundidade: $1,90 \mathrm{~m}$ & N.A. Estab: $1,10 \mathrm{~m}$ & Profundidade: $6,80 \mathrm{~m}$ & N.A. Estab.: $5,20 \mathrm{~m}$ & Profundidade: $7,00 \mathrm{~m}$ & N.A. Estab.: $6,00 \mathrm{~m}$ \\
\hline
\end{tabular}

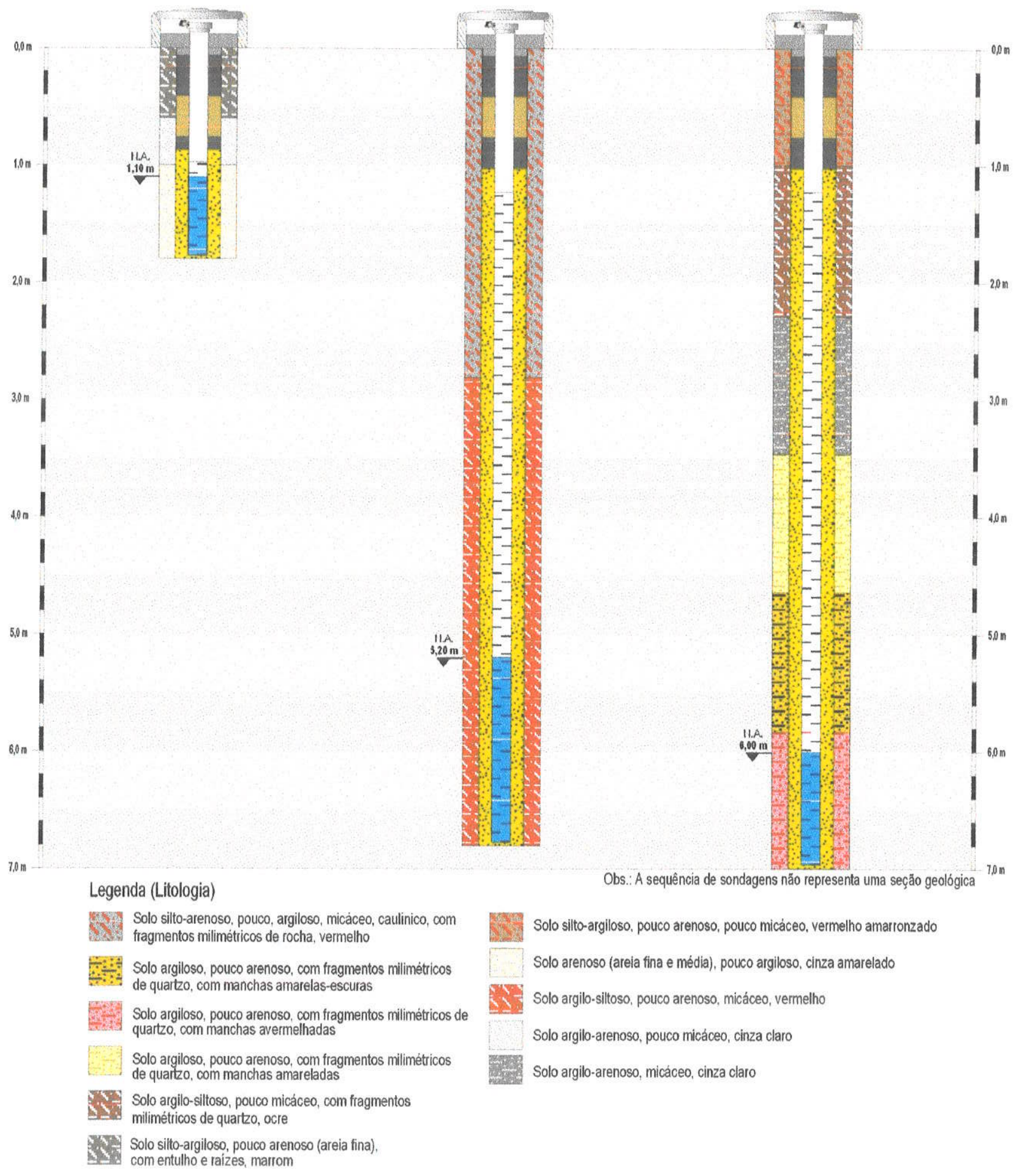




\begin{tabular}{|l|l|l|l|l|l|l|}
\hline \multicolumn{2}{|c|}{ EQUIPAMENTO: TRADO MANUAL } & \multicolumn{2}{c|}{ PERFURAÇÃO: 4" } & \multicolumn{2}{c|}{ REVESTIMENTO: 2" } \\
\hline \multicolumn{2}{|c|}{ PM-13 } & \multicolumn{3}{c|}{ PM-14 } & \multicolumn{2}{c|}{ PM-15 } \\
\hline Inicio: $08 / 1998$ & Término: $08 / 1998$ & Inicio: 08/1998 & Término: 08/1998 & Inicio: 08/1998 & Término: 08/1998 \\
\hline Profundidade: $4,00 \mathrm{~m}$ & N.A. Estab: $2,50 \mathrm{~m}$ & Profundidade: $2,70 \mathrm{~m}$ & N.A. Estab.: $1,50 \mathrm{~m}$ & Profundidade: $3,00 \mathrm{~m}$ & N.A. Estab.: $1,80 \mathrm{~m}$ \\
\hline
\end{tabular}

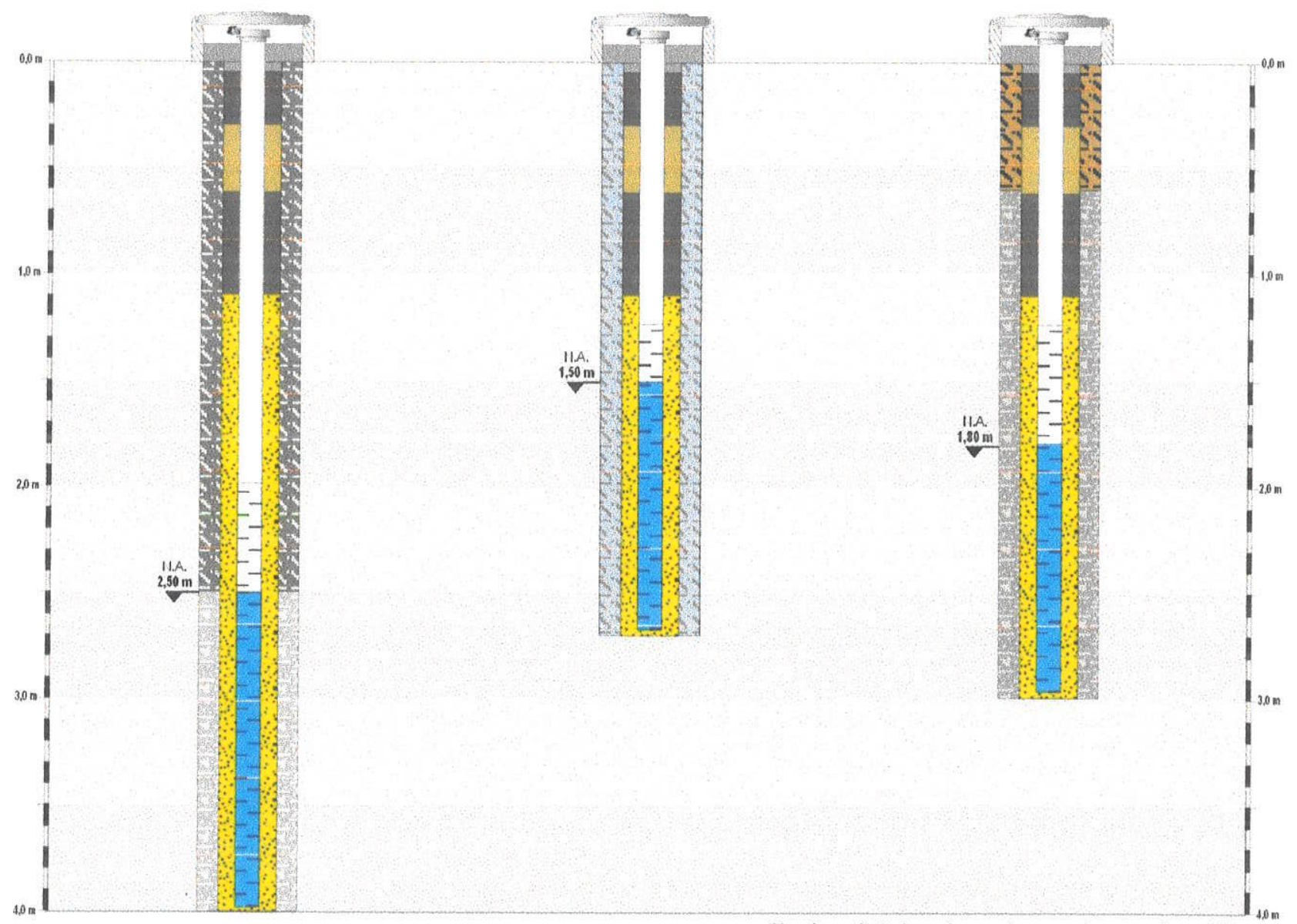

Legenda (Litologia)

Solo argilo-siltoso, preto
Solo argiloso, pouco arenoso, pouco micáceo, cinza
Solo silto-argiloso, com entulho, com porçöes arenosas, preto
Solo silto-argiloso, pouco arenoso, com entulho e pedregulhos, bege à marrom escuro
Solo argiloso, pouco arenoso, micáceo, cinza




\begin{tabular}{|c|c|c|c|c|}
\hline EQUIPAMENTO: TRADO MANUAL & PERFURAÇÃO: 4" & \multicolumn{2}{|c|}{ REVESTIMENTO: 2" } \\
\hline PM-16 & PM-17 & PM-18 & PM-19 \\
\hline Inicio: 08/1998 & Início: 08/1998 & Inicio: 08/1998 & Início: 08/1998 \\
\hline Término: 08/1998 & Término: 08/1998 & Término: 08/1998 & Término: 08/1998 \\
\hline N.A. Estab: $1,80 \mathrm{~m}$ & N.A. Estab.: $3,60 \mathrm{~m}$ & N.A. Estab.: $2,60 \mathrm{~m}$ & N.A. Estab.: $4,00 \mathrm{~m}$ \\
\hline Profundidade: $3,00 \mathrm{~m}$ & Profundidade: $5,00 \mathrm{~m}$ & Profundidade: $3,90 \mathrm{~m}$ & Profundidade: $3,10 \mathrm{~m}$ \\
\hline
\end{tabular}

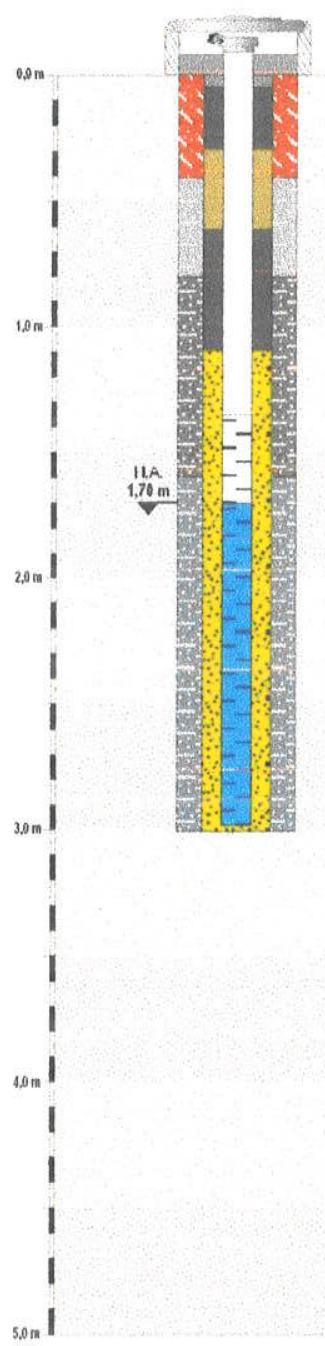

Legenda (Litologia)

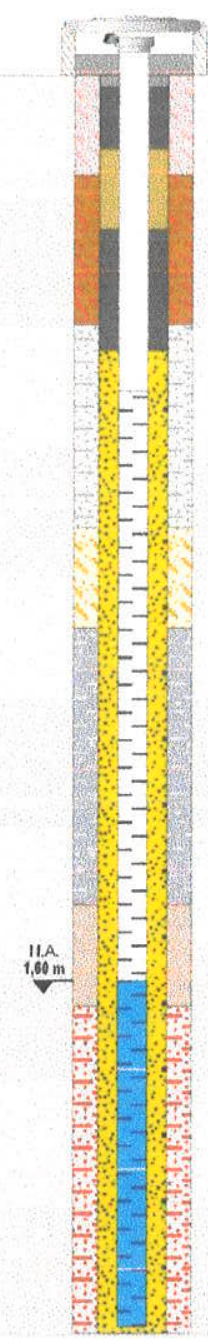
Solo argiloso, pouco arenoso, pouco micáceo, com fragmentos
milimétricos de quartzo, amarelo com intercalaçoes vermelhas

Solo arenoso (areia fina), pouco siltoso, com fragementos milimétricos de rocha, micáceo, amarelo claro

Solo argilo-siltoso, pouco arenoso, com fragmentos miliméricos de rocha, pouco micacea, variegada

Solo arenoso (areia fina, média e grossa), pouco argilosa. micáceo, marrom avermelhada

Solo silto-arenoso, pouco argiloso, com pedregulhos e entulho, micáceo, vermelho

Solo argilo-arenoso, micáceo, com fragmentos milimètricos de rocha, cinza-claro

- Solo areno-argiloso (areia fina e média), micáceo, vermelha e amarela

Solo argilo-siltoso, com fragmentos miliméricos de rocha e matéria 1. orgânica, cinza-escuro

5.:. Solo argiloso, pouco arenoso, pouco micáceo, cinza

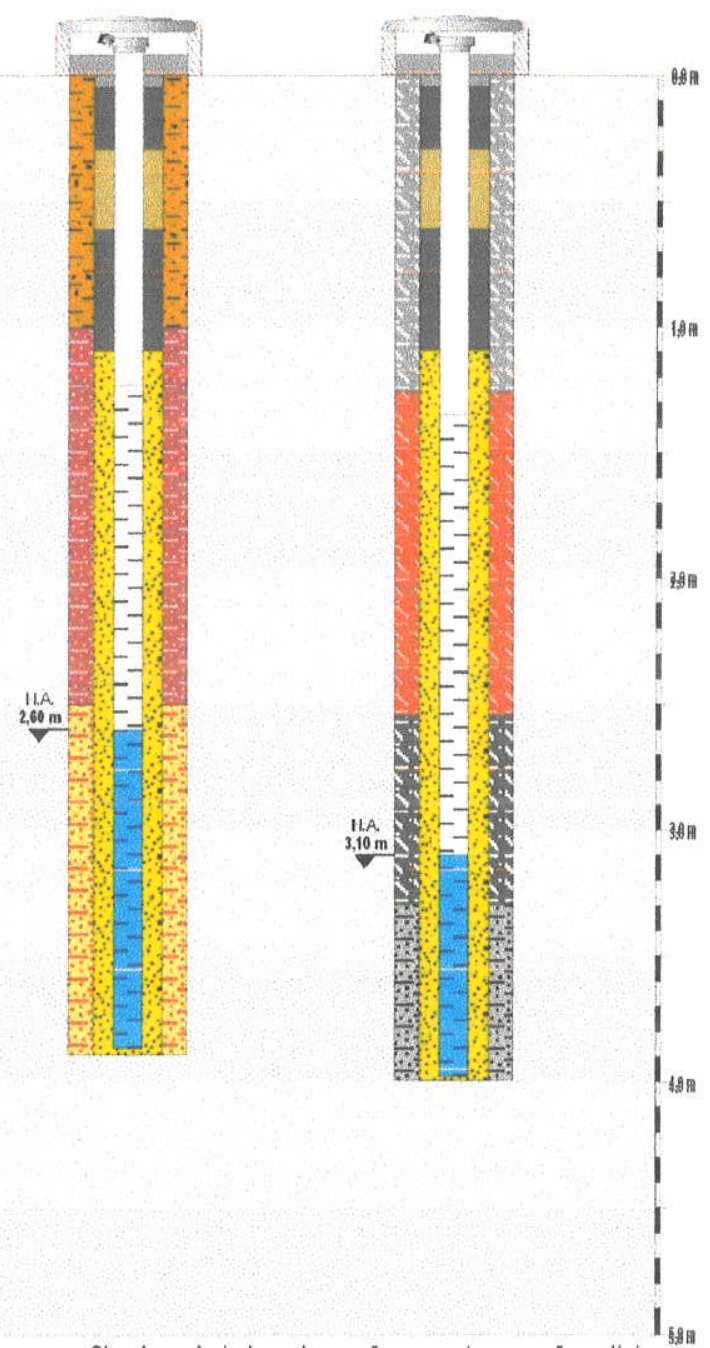

Obs.: A sequência de sondagens năo representa uma seção geológica

Solo argilo-siltoso, pouco arenoso, amarelo, com manchas pretas

Solo argilo-arenoso, cinza-escuro, com làminas de material preto

5. Solo silto-arenoso, pouco argiloso, com entulho, vermelho

Solo arenoso, pouco argiloso, micáceo, cinza-escuro

Solo argilo-sittoso, pouco arenoso, ocre a marrom

Solo argiloso, pouco arenoso, cinza-escuro

Solo argilo-arenoso, micáceo, vermelha

Solo argilo-siltoso, pouco arenoso, avermelhado

Solo argilo-siltoso, cinza-escuro à preto 


\section{APÊNDICE II}

Resultados Analíticos do Monitooramento realizado em Outubro de 1998 


\begin{tabular}{|c|c|c|c|c|c|c|c|c|c|c|c|c|c|c|c|c|c|c|}
\hline$\overbrace{}^{\circ}$ & 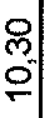 & & & $\mp$ & & 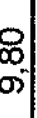 & $m$ & & & & & & & & & & & 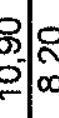 \\
\hline $\begin{array}{l}0 \\
\mathcal{O}\end{array}$ & $\begin{array}{l}\text { N } \\
\text { o } \\
\text { In }\end{array}$ & $\begin{array}{l}\text { Pे } \\
\text { iv }\end{array}$ & ; & 2 & (6) & $\mathcal{N}$ & m. & & $\mid$ & ल & 8 & & & & & & & \begin{tabular}{l|l}
$r$ & 0 \\
$v$ & 0
\end{tabular} \\
\hline 今' & $\begin{array}{l}8 \\
8 \\
8\end{array}$ & $\begin{array}{l}8 \\
8 \\
0 \\
\end{array}$ & & 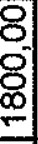 & $\begin{array}{l}8 \\
8 \\
0 \\
0\end{array}$ & $\begin{array}{l}8 \\
8 \\
0 \\
\end{array}$ & 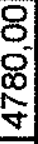 & $\begin{array}{l}8 \\
-0 \\
8\end{array}$ & $\begin{array}{l}8 \\
-8 \\
\bar{్} \\
\overline{6} \\
0\end{array}$ & $\begin{array}{l}8 \\
8 \\
8\end{array}$ & & v & \begin{tabular}{l}
8 \\
8 \\
8 \\
\hdashline \\
\hdashline \\
\end{tabular} & $\begin{array}{l}8 \\
8 \\
\end{array}$ & & & 8 & 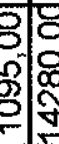 \\
\hline$\overline{0}$ & $\begin{array}{l}8 \\
5\end{array}$ & $\begin{array}{l}8 \\
0 \\
5 \\
5\end{array}$ & إم & 8 & $0^{\circ}$ & $\sigma^{\circ}$ & $\begin{array}{l}8 \\
0 \\
0\end{array}$ & 0 & $\begin{array}{l}8 \\
8 \\
0\end{array}$ & $\begin{array}{l}8 \\
6 \\
10\end{array}$ & 8 & N & & & 8 & 8 & $\begin{array}{l}8 \\
8 \\
8\end{array}$ & \begin{tabular}{l}
8 \\
8 \\
\hdashline \\
\hdashline
\end{tabular} \\
\hline L & ర্) & $\begin{array}{l}\text { ్․ } \\
\text { ol }\end{array}$ & $\begin{array}{l}0 \\
v\end{array}$ & $0^{\circ}$ & 5 & o) & 5 & ol & $\check{0}_{0}$ & 이 & $\overline{0}^{-}$ & - & $\begin{array}{l}R \\
0 \\
0\end{array} \mid$ & 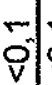 & : & & : & $\begin{array}{c}0 \\
0 \\
\end{array}$ \\
\hline के & 足 & $\begin{array}{l}\text { 員 } \\
\text { int }\end{array}$ & & D & ला & ?יר & 8 & $\mathrm{~N}$ & $\begin{array}{l}8 \\
0 \\
0\end{array}$ & 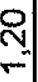 & $\bar{\delta}$ & 5 & $\begin{array}{c}m \\
0 \\
0\end{array} \mid$ & लि & $\begin{array}{l}8 \\
8 \\
0\end{array}$ & & $\begin{array}{c}\text { D̂. } \\
\text { - }\end{array}$ & $\begin{array}{l}8 \\
\end{array}$ \\
\hline 8 & $\begin{array}{l}\text { ? } \\
0 \\
0 \\
v\end{array}$ & $\begin{array}{l}\text { 영 } \\
8\end{array}$ & & లl & \begin{tabular}{l}
2 \\
2 \\
0 \\
\hdashline
\end{tabular} & 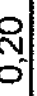 & $\begin{array}{l}0 \\
8\end{array}$ & 인 & 이 & $\begin{array}{l}0 \\
8 \\
0\end{array}$ & ᄋ̊ & 응 & & & $\underline{0}$ & $\begin{array}{l}\text { s } \\
\text { vo }\end{array}$ & & 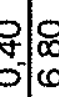 \\
\hline $\bar{N}$ & $\begin{array}{c}9 \\
-1 \\
N\end{array}$ & $\begin{array}{l}\text { 여 } \\
\varnothing \\
\varnothing\end{array}$ & \begin{tabular}{l}
$N$ \\
\hdashline \\
$\Sigma$
\end{tabular} & 인 & 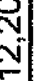 & $\begin{array}{c}0 \\
5\end{array}$ & 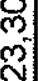 & त & $\begin{array}{l}0 \\
\stackrel{0}{N} \\
N\end{array}$ & o. & 용 & 1 & 앙 & $\begin{array}{l}8 \\
0 \\
\mathrm{v}\end{array}$ & ? & & के & 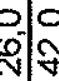 \\
\hline 0 & $\begin{array}{l}0 \\
0 \\
0 \\
0 \\
v\end{array}$ & $\begin{array}{l}0 \\
0 \\
0 \\
\gamma\end{array}$ & $\begin{array}{l}8 \\
0 \\
0 \\
0\end{array}$ & 8 & శి & 8 & $\begin{array}{l}10 \\
0 \\
0 \\
\text { v }\end{array}$ & $\begin{array}{l}0 \\
0 \\
0\end{array}$ & $\begin{array}{l}\text { ? } \\
0 \\
0 \\
V\end{array}$ & 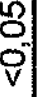 & \% & $\begin{array}{l}\text { D } \\
0 \\
0 \\
v\end{array}$ & & $\begin{array}{l}0 \\
0 \\
0 \\
v\end{array}$ & $\begin{array}{l}8 \\
\text { s. } \\
\text { v }\end{array}$ & g & ô. & 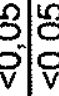 \\
\hline J & 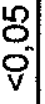 & 怘 & 애 & 잉 & 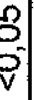 & 8 & $\stackrel{2}{2}$ & 요 & $\frac{\nabla}{0}$ & 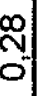 & $\begin{array}{l}\text { O } \\
0 \\
0 \\
v\end{array}$ & 응 & $\frac{N}{0}$ & $\begin{array}{l}2 \\
0 \\
\text { va }\end{array}$ & & & & \begin{tabular}{c|c}
$\stackrel{2}{*}$ \\
0
\end{tabular} \\
\hline c & $\begin{array}{l}8 \\
8 \\
m^{\prime}\end{array}$ & $\begin{array}{c}0 \\
0 \\
0 \\
\text { va }\end{array}$ & $\begin{array}{l}0 \\
8 \\
\varnothing \\
\infty\end{array}$ & $\begin{array}{l}0 \\
\text { o: }\end{array}$ & ه্. & $\stackrel{8}{2}$ & $\begin{array}{l}\text { 영 } \\
8\end{array}$ & $\begin{array}{l}0 \\
0 \\
0 \\
\end{array}$ & 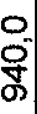 & 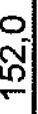 & $\stackrel{s}{\mathrm{v}}$ & $\begin{array}{l}\text { ô } \\
\text { - } \\
\text { m. }\end{array}$ & $\begin{array}{l}0 \\
\stackrel{0}{\$} \\
\stackrel{5}{0}\end{array}$ & $\begin{array}{l}0 \\
0 \\
\text { ○ी }\end{array}$ & $\begin{array}{l}0 \\
8 \\
8 \\
\end{array}$ & & 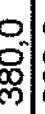 & 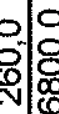 \\
\hline 送 & $\frac{-1}{8}$ & $\begin{array}{l}\text { ㄱ. } \\
\circ\end{array}$ & 인 & 5 & 5 & $\begin{array}{l}- \\
6 \\
v\end{array}$ & 5 & -1 & $\begin{array}{l}0 \\
\text { - } \\
0\end{array}$ & প్ల & 5 & -1 & $\begin{array}{l}\text { 워 } \\
\forall\end{array}$ & $\begin{array}{l}\circ \\
\infty\end{array}$ & : & 0 & of & b. \\
\hline$\stackrel{0}{2}$ & 응 & 영 & 이 & 앙. & 잉 & 8 & 0 & 요 & $\begin{array}{l}0 \\
\text { ద్ }\end{array}$ & 요 & $\stackrel{\sim}{N}$ & 8 & 은 & $=$ & $\begin{array}{l}0 \\
0 \\
0\end{array}$ & & 8 & \begin{tabular}{l|l}
$D^{\infty}$ & \\
$F$ \\
$F$
\end{tabular} \\
\hline 今 & $\begin{array}{l}\text { 워 } \\
\text { m- }\end{array}$ & $\begin{array}{l}0 \\
0 \\
8 \\
\end{array}$ & & $\begin{array}{l}0 \\
0 \\
0\end{array}$ & $\begin{array}{l}8 \\
5 \\
5\end{array}$ & o & 0 & o. & 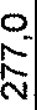 & 0 & & ㅇ. & $\stackrel{\circ}{\circ}$ & & s. & $?$ & . & 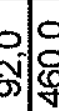 \\
\hline$x$ & $\begin{array}{l}\text { 임 } \\
\text { ?2 }\end{array}$ & 일 & & 의 & 0 & 0 & 8 & 으. & $\stackrel{\circ}{8}$ & of & 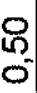 & e & 0 & $\begin{array}{l}0 \\
0 \\
0\end{array}$ & $P^{\prime}$ & 0 & 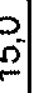 & \begin{tabular}{l|c|c}
0 & 0 \\
$\infty$ & 8
\end{tabular} \\
\hline$\frac{\pi}{2}$ & \begin{tabular}{l} 
엉 \\
\multirow{N}{*}{}
\end{tabular} & $\begin{array}{l}\text { 영 } \\
6 \\
1\end{array}$ & $c$ & & & & & 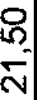 & & & & & 品 & $\begin{array}{l}\text { Oे } \\
\text { m. }\end{array}$ & & & 8 & $\begin{array}{c}\text { êm: } \\
\end{array}$ \\
\hline $\begin{array}{l}\text { : } \\
\text { סू } \\
0\end{array}$ & 员 & $\begin{array}{l}0 \\
0 \\
\vdots \\
\vdots \\
\vdots\end{array}$ & & & & & & & & & & & $\frac{m}{\frac{m}{1}}$ & $\frac{\nabla}{\sum_{0}^{7}}$ & & & & $\frac{\infty}{a} \frac{\infty}{2}$ \\
\hline
\end{tabular}




\section{APÊNDICE III}

Resultados Analíticos do Monitoramento realizado em abril de 1999 

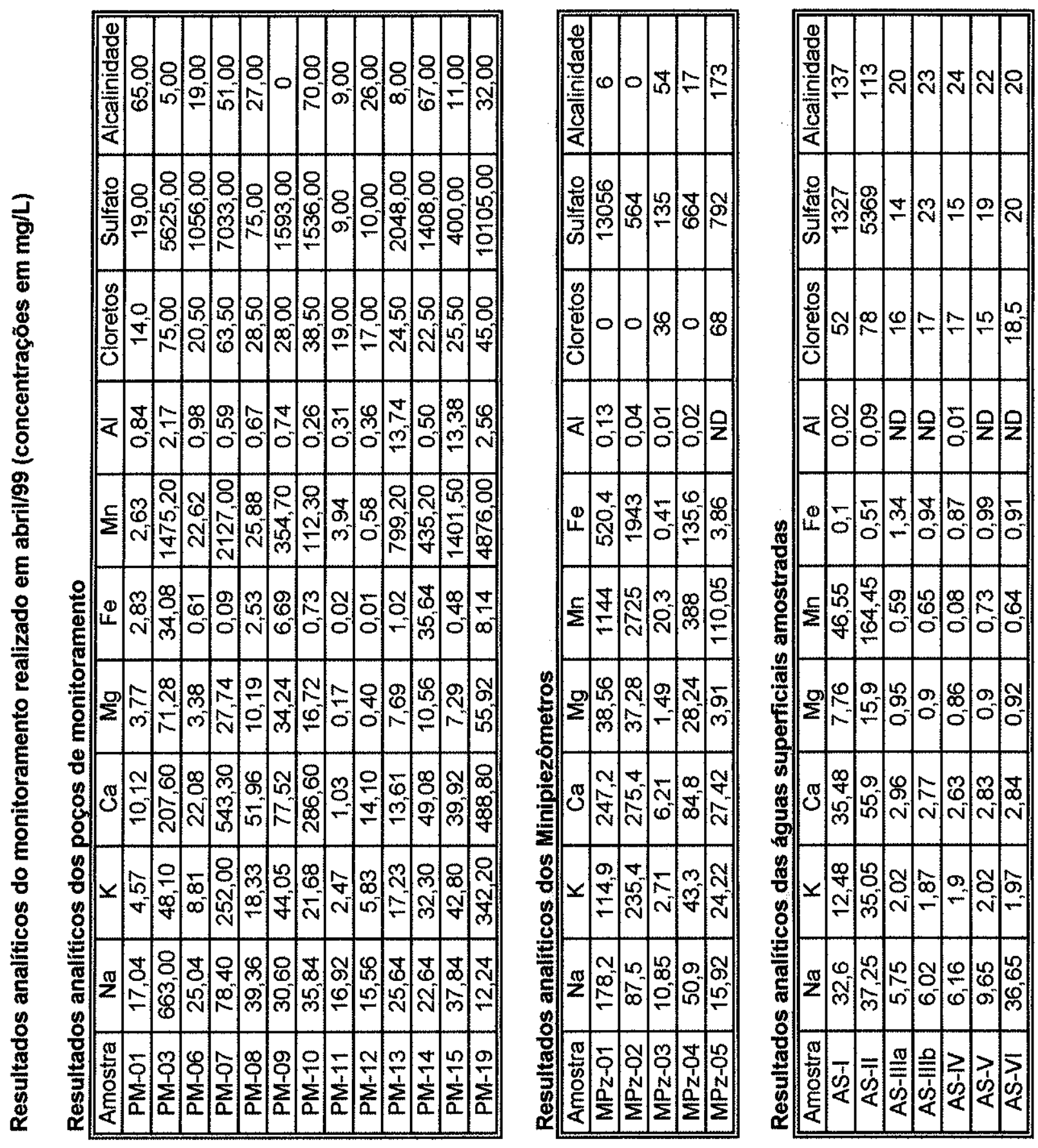


\section{APÊNDICE IV}

Dados de entrada do programa Wateq4f referente ao PM-01 
Delete previous file-<Y/N $>$ ?:

yes

\section{WELCOME TO WQ4FINPT!}

NOTE: This version does not accept sigmas.

Hitting <Enter> always selects the indicated default value.

If no default is indicated, it is zero.

\section{OUTPUT FILE SELECTION}

Hit < Enter> to append data to file WATEQ4F.DAT

Otherwise, enter the name of a different file:

Enter descriptor (72 chars maximum, <Enter> to QUIT):

PM-01 (abril99)

Enter dataset number ( 5 character maximum):

agua

Enter plot symbol (1 char only):

1

RECORD 1:

$\star * * *$

PM-01 (abril99)

agua 1

Is this data OK (<Enter>=Yes)?

yes

Enter Conductivity(uS)

Default $=0.0$

Enter Total Diss Solids

Default $=0.0$ 
Enter Date( 6 chars max)

Default $=00$

Enter Discharge(cfs)

Default $=0.0$

Enter Diss Org Carbon

Default $=0.0$

Enter Salinity(o/oo)

Default $=0.0$

Enter $\mathrm{Cr}$

Default $=0.0$

Enter Co

Default $=0.0$

Enter Mo

Default $=0.0$

Enter V

Default $=0.0$

RECORDS 1 AND 2:

****

PM-01 (abril99) agua 1

$\begin{array}{llllllllll}0 . & 0 . & 0 & .0000 & .0000 & .0000 & .0000 & .0000 & .0000 & .0000\end{array}$

Is this data OK $(<$ Enter $>=$ Yes $)$ ?

yes

Enter Temperature(deg C)

Default $=25.0$

19

Enter pH

Default $=7.0$

6.43

Enter Eh 
Default $=9.9$

0.493

Enter Dissolved Oxygen

Default $=0.0$

CORALK options:

0 . Alkalinity input has not been corrected for noncarbonate species (the default)

1. Alkalinity input has been corrected for noncarbonate species

2. Alkalinity input is total carbon

Enter CORALK

Default $=0$

RECORDS O THROUGH 4:

****

PM-01 (abril_99)

agua 1

$\begin{array}{llllllllll}0 . & 0 . & 0 & .0000 & .0000 & .0000 & .0000 & .0000 & .0000 & .0000\end{array}$

TEMP-.-- PH--.--- EHM-.-- DOC--.-- DOX--.-- CORALK--

$\begin{array}{llllll}19.00 & 6.43 & .493 & .00 & .00 & 0\end{array}$

Is this data OK (<Enter $>=Y e s) ?$

yes

Flag options:

1. $\mathrm{mg} / \mathrm{L}$ (the default)

2. $\mathrm{ppm}$

3. $\mathrm{meq} / \mathrm{L}$

4. $\mathrm{mmol} / \mathrm{L}$

5. $\mathrm{mol} / \mathrm{kg}$

Enter Flag Option

Default $=1$ 
1

Enter Density

Default $=1.0$

Print options:

0 . Print minimum output (the default)

1. Print complete aqueous speciation and mineral solubility listing

2. Print minimum output plus weight and molar ratios page

3. Print complete output (1 plus 2)

4. 0 plus generate the thermodynamic data table

5. 1 plus generate the thermodynamic data table

6. 2 plus generate the thermodynamic data table

7. 3 plus generate the thermodynamic data table

Enter Print Option

Default $=0$

Eh options:

0 . Use measured Eh (the default)

1. Use $\mathrm{Fe} 2 / 3 \mathrm{Eh}$

2. Use $\mathrm{H} 2 \mathrm{O} / \mathrm{O} 2$ Eh with Sato relation

3. Use $\mathrm{H} 2 \mathrm{O} / \mathrm{O} 2$ Eh w/classical relation

4. Use $\mathrm{NH} 4 / \mathrm{NO} 3 \mathrm{Eh}$

5. Use S-2/SO4 Eh

6. Use $\mathrm{NO} 2 / \mathrm{NO}_{3} \mathrm{Eh}$

7. Use $S-2 / S(s)$ Eh

8. Use As $3 / 5 \mathrm{Eh}$

9. Use As(s)/As + 3 Eh

10. Use Se 4/6 Eh

11. Use $\mathrm{Se}(\mathrm{s}) / \mathrm{Se}+4 \mathrm{Eh}$

12. Use $\mathrm{Se}-2 / \mathrm{Se}(\mathrm{s}) \mathrm{Eh}$ 
13. Use U 4/6 Eh

NOTE: Use these options with caution! To use

an option you must have input data for the

redox specie or species referred to.

1. Enter number of Eh to use for Fe species distribution

Default $=0$

2. Enter number of Eh to use for Mn species other than +2

Default $=0$

3. Enter number of Eh to use for $\mathrm{Cu}+1$ species

Default $=0$

4. Enter number of Eh to use for As species distribution

Default $=0$

5. Enter number of Eh to use for Se species distribution

Default $=0$

6. Enter number of Eh to use for Ion Activity Product calculations

Default $=0$

7. Enter number of Eh to use for $\mathrm{pO} 2$ calculation

Default $=0$

8. Enter number of Eh to use for $\mathrm{H} 2 \mathrm{~S}$ from $\mathrm{SO} 4, \mathrm{pH}$ and $\mathrm{Eh}$

Default $=0$

9. Enter number of Eh to use for $U$ species distribution

Default $=0$

RECORDS 0 THROUGH 8:

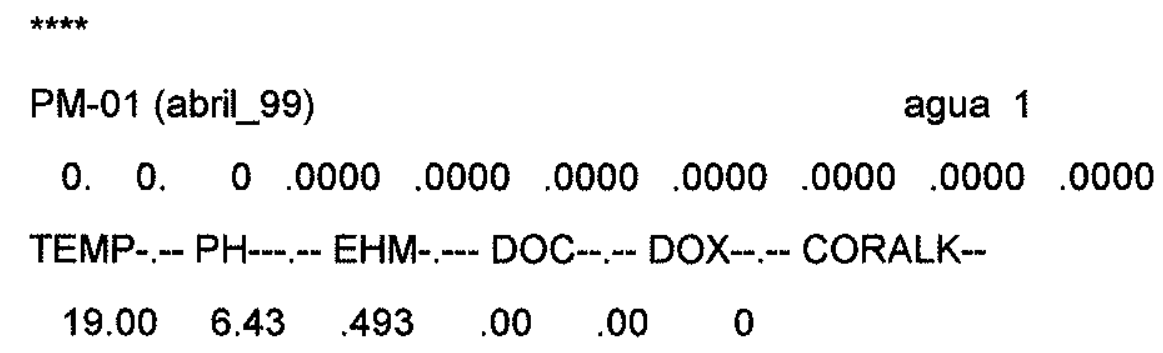


FLAG---DE.NS---- PRNT PUNCH EHOPT:-1--2--3--4--5--6--7--8--9

MG/L $1.000000 \quad 0 \quad 1 \quad 000000000000$

EMPOX--- ITDS-.-- COND-.-- SIGMDO-.---SIGMEH-.---SIGMPH-.-.-

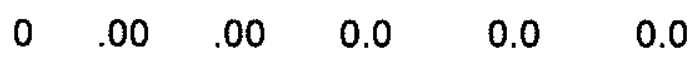

Is this data OK (<Enter>=Yes)?

yes

Enter $\mathrm{Ca}$

Default $=0.0$

10.12

Enter Mg

Default $=0.0$

3.77

Enter $\mathrm{Na}$

Default $=0.0$

17.04

Enter K

Default $=0.0$

4.57

Enter $\mathrm{Cl}$

Default $=0.0$

14

Enter SO4

Default $=0.0$

19

RECORDS 0 THROUGH 10:

PM-01 (abril_99) agua 1

$\begin{array}{llllllllll}0 . & 0 . & 0 & 0000 & .0000 & .0000 & .0000 & .0000 & .0000 & .0000\end{array}$

TEMP-..- PH--..-- EHM-.-- DOC--.-- DOX--.-- CORALK-- 
$\begin{array}{llllll}19.00 & 6.43 & .493 & .00 & .00 & 0\end{array}$

FLAG---DE.NS---- PRNT PUNCH EHOPT:-1--2--3--4--5--6--7--8--9

MG/L $1.000000 \quad 0 \quad 1 \quad 000000000000$

EMPOX--- ITDS-.-- COND-.-- SIGMDO-.----SIGMEH-.--.-SIGMPH-.----

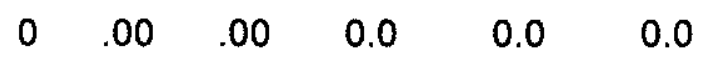

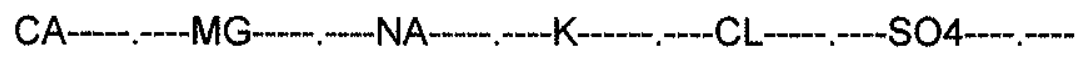

$\begin{array}{llllll}10.1200 & 3.7700 & 17.0400 & 4.5700 & 14.0000 & 19.0000\end{array}$

Is this data OK (<Enter $>=$ Yes)?

yes

Enter $\mathrm{HCO} 3$

Default $=0.0$

65

Enter Fe(total)

Default $=0.0$

2.83

Enter $\mathrm{H} 2 \mathrm{~S}$

Default $=0.0$

Enter $\mathrm{CO} 3$

Default $=0.0$

Enter SiO2

Default $=0.0$

Enter NH4

Default $=0.0$

RECORDS 0 THROUGH 12:

****

PM-01 (abril_99) agua 1

$\begin{array}{llllllllll}0 . & 0 . & 0 & 0000 & .0000 & .0000 & .0000 & .0000 & .0000 & .0000\end{array}$

TEMP-.-- PH-...-- EHM-.--- DOC--.-- DOX--.-- CORALK-- 
$\begin{array}{llllll}19.00 & 6.43 & .493 & .00 & .00 & 0\end{array}$

FLAG---DE.NS---- PRNT PUNCH EHOPT:-1--2--3--4--5--6--7--8---9

MG/L $\quad 1.000000 \quad 0 \quad 1 \quad 000000000000$

EMPOX--- ITDS-.-- COND-.-- SIGMDO-.----SIGMEH-.----SIGMPH-.----

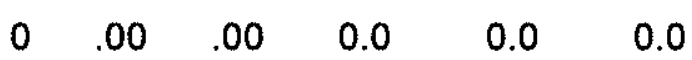

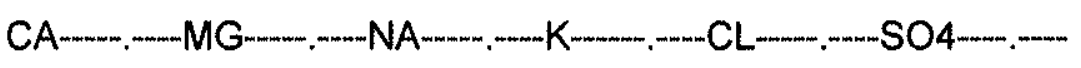

$\begin{array}{llllll}10.1200 & 3.7700 & 17.0400 & 4.5700 & 14.0000 & 19.0000\end{array}$

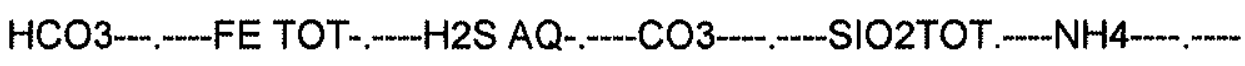

$\begin{array}{llllll}65.0000 & 2.8300 & .0000 & .0000 & .0000 & .0000\end{array}$

Is this data OK (<Enter $>=$ Yes $)$ ?

yes

Enter B

Default $=0.0$

Enter PO4

Default $=0.0$

Enter Al

Default $=0.0$

0.84

Enter F

Default $=0.0$

Enter NO3

Default $=0.0$

RECORDS 0 THROUGH 14:

PM-01 (abril_99) agua 1

$\begin{array}{llllllllll}0 . & 0 . & 0 & 0000 & .0000 & .0000 & .0000 & .0000 & .0000 & .0000\end{array}$

TEMP-.-- PH---.-- EHM-.--- DOC--.-- DOX--.-- CORALK--

$\begin{array}{llllll}19.00 & 6.43 & .493 & .00 & .00 & 0\end{array}$

FLAG---DE.NS---. PRNT PUNCH EHOPT:-1--2--3--4--5--6-1--8--9 


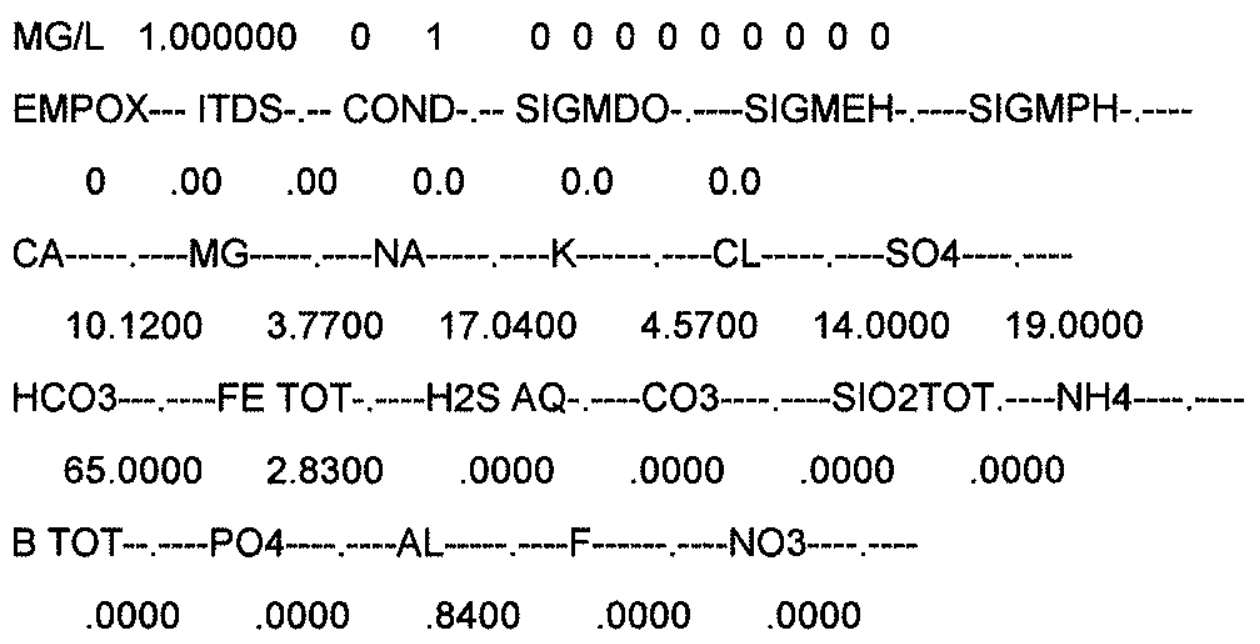

Is this data OK (<Enter $>=Y e s)$ ?

yes

Enter $\mathrm{Fe}(+2)$

Default $=0.0$

Enter $\mathrm{Fe}(+3)$

Default $=0.0$

Enter Cs

Default $=0.0$

Enter Li

Default $=0.0$

Enter Sr

Default $=0.0$

Enter Ba

Default $=0.0$

Enter Rb

Default $=0.0$

Enter I

Default $=0.0$

Enter $\mathrm{Br}$

Default $=0.0$

Enter Mn 
Default $=0.0$

2.63

Enter $\mathrm{Cu}$

Default $=0.0$

Enter Zn

Default $=0.0$

Enter Cd

Default $=0.0$

Enter $\mathrm{Pb}$

Default $=0.0$

Enter NO2

Default $=0.0$

Enter $\mathrm{Ni}$

Default $=0.0$

Enter Ag

Default $=0.0$

Enter As(total)

Default $=0.0$

Enter As(+3)

Default $=0.0$

Enter As $(+5)$

Default $=0.0$

Enter Fulvate

Default $=0.0$

Enter Humate

Default $=0.0$

Enter Se(total

Default $=0.0$

Enter H2Se

Default $=0.0$

Enter Se(+4) 
Default $=0.0$

Enter $\mathrm{Se}(+6)$

Default $=0.0$

Enter U(total)

Default $=0.0$

Enter $U(+4)$

Default $=0.0$

Enter $U(+6)$

Default $=0.0$

Eh inconsistency tests completed.

Press $<$ Enter $>$ to continue. . .

FINAL DATA:

PM-01 (abril_99)

agua 1

$\begin{array}{llllllllll}0 . & 0 . & 0 & .0000 & .0000 & .0000 & .0000 & .0000 & .0000 & .0000\end{array}$

TEMP-.-- PH--.-.- EHM-.-- DOC--.-- DOX--.-- CORALK--

$\begin{array}{llllll}19.00 & 6.43 & .493 & .00 & .00 & 0\end{array}$

FLAG---DE.NS--- PRNT PUNCH EHOPT:-1--2--3--4--5--6--7--8--9

MG/L $1.000000 \quad 0 \quad 1 \quad 00000000000$

EMPOX--- ITDS-.-- COND-.-- SIGMDO-.-.-.SIGMEH-.-.-SIGMPH-..-..

$\begin{array}{llllll}0 & .00 & .00 & 0.0 & 0.0 & 0.0\end{array}$

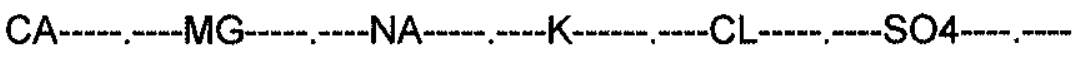

$\begin{array}{llllll}10.1200 & 3.7700 & 17.0400 & 4.5700 & 14.0000 & 19.0000\end{array}$

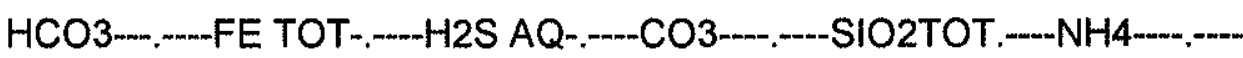

$\begin{array}{llllll}65.0000 & 2.8300 & .0000 & .0000 & .0000 & .0000\end{array}$

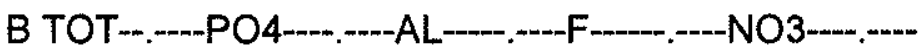

$\begin{array}{lllll}.0000 & .0000 & .8400 & .0000 & .0000\end{array}$ 
CUN $109 \quad 2.63000$

Is this data OK (<Enter $>=$ Yes)?

yes

Store this data set on disk?

yes

Data set now being appended to file WATEQ4F.DAT

Enter descriptor (72 chars maximum, <Enter> to QUIT):

Exiting this program. Your data file name is WATEQ4F.DAT

WQ4FINPT exited normally.

PM-01 (abril_99)

agua 15

Stop - Program terminated. 